\title{
Hydrology and Geochemistry of Thermal Springs of the Appalachians
}

GEOLOGICAL SURVEY PROFESIONAL PAPER 1044-E
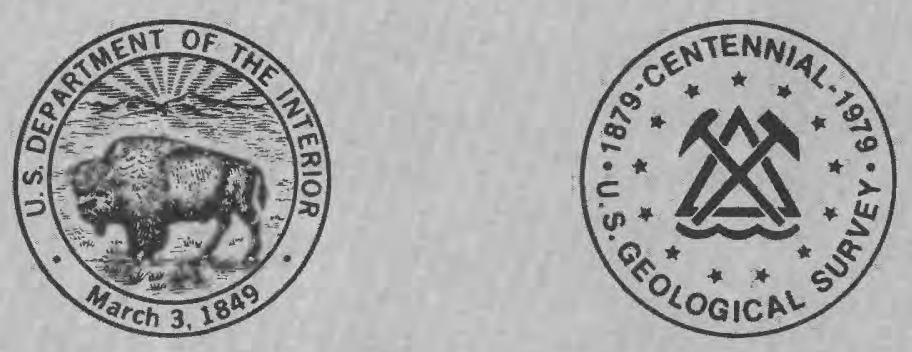



\section{Hydrology and Geochemistry of Thermal Springs of the Appalachians}

By W.A. HOBBA, JR., D. W. FISHER, F. J. PEARSON, JR., and J. C. CHEMERYS

GEOH Y D OLOGY OF GEOTHERMAL SYSTEMS

GEOLOGICAL SURVEY PROFESSIONAL PAPER $1044-\mathrm{E}$

A study of the geologic and hydrologic setting

and the physical and chemical character

of selected major warm springs

of the Appalachians

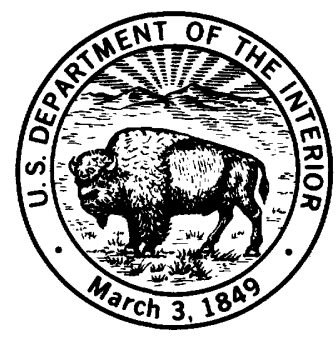




\section{UNITED STATES DEPARTMENT OF THE INTERIOR}

CECIL D. ANDRUS, Secretary

\section{GEOLOGICAL SURVEY}

H. William Menard, Director

Main entry under title:

Hydrology and geochemistry of thermal springs of the Appalachians.

(Geohydrology of geothermal systems) (Geological Survey professional paper; 1044-E) Bibliography: $p$.

Supt. of Docs. no.: I 19.16:1044-E

1. Hot springs-Appalachian Mountains. 2. Geochemistry-Appalachian Mountains. I. Hobba, W.A. II. Series. III. Series: United States. Geological Survey. Professional paper; 1044-E.

GB1198.3.A57H92 551.2’3’0974 79-607987

For sale by the Superintendent of Documents, U.S. Government Printing Office Washington, D.C. 20402

Stock Number 024-001-03218-0 


\section{CONTENTS}

\begin{tabular}{|c|c|c|c|}
\hline & Page & & Page \\
\hline Abstract & E 1 & Geochemistry-Continued & \\
\hline Introduction - & 1 & Geochemical indicators & E21 \\
\hline Purpose and scope & 1 & Dissolved gases & 21 \\
\hline Previous studies & 1 & Trace elements & 23 \\
\hline Acknowledgments & 3 & Isotopes & 23 \\
\hline Historical background & 3 & Carbonate chemistry and isotopes & 26 \\
\hline Geologic and hydrologic setting, by W. A. Hobba, Jr & 4 & Chemical geothermometers & 27 \\
\hline General description of the springs & 4 & Discussion & 29 \\
\hline Physical setting & 4 & Silica-rock spring systems & 29 \\
\hline Geology and topography & 4 & Perry County, Pa., area & 30 \\
\hline Rock structure & 4 & Berkeley Springs, W. Va., area & 30 \\
\hline Hydrology - & 11 & Minnehaha Springs, W. Va., area & 30 \\
\hline Probable flow systems & 11 & Warm Springs, Ga., area & 30 \\
\hline Selected flow systems & 13 & Carbonate-rock spring systems & 31 \\
\hline Temperature of thermal waters & 17 & Lebanon Springs, N. Y., area & 31 \\
\hline Fluctuations & 17 & Bolar Spring, Warm Springs, Hot Springs, & \\
\hline Wells and thermal gradients & 18 & and Falling Spring, Va., areas & 32 \\
\hline Heat discharge & 20 & Hot Springs, N. C., area & 33 \\
\hline Geochemistry, by D. W. Fisher, F. J. Pearson, Jr., and & & Conclusions & 34 \\
\hline J. C. Chemerys & 20 & References cited & \\
\hline General principles & 20 & & \\
\hline
\end{tabular}

\section{ILLUSTRATIONS}

FIGURE 1. Photograph of Homestead Hotel and Hot Sulphur Spring at Hot Springs, Va Page

2. Satellite images of thermal spring areas in Virginia, West Virginia, Georgia, and New York

3. Side-looking radar images showing prominent lineaments and thermal springs and wells in Virginia, West Virginia, and Georgia

4. Map showing geology, spring, and well locations in Minnehaha Springs area, West Virginia

5. Cross section parallel to fault passing near Webster Springs and Minnehaha Springs, W. Va., and

6. Map showing lineaments and their relationship to thermal springs in Virginia and West Virginia

7. Photograph of sandstone quarry looking southwest toward Berkeley Springs, W. Va

8. Cross section showing theoretical movement of ground water through a homogeneous isotropic aquifer with an impermeable layer at $1,500 \mathrm{~m}$

9. Cross section showing possible movement of ground water through a multilayered folded, faulted, and fractured aquifer such as those in Warm Springs Valley, Va

10. Block diagram showing possible circulation of water to a warm spring located near the crest of an anticline at the intersection of two faults

11. Diagram showing possible movement of ground water through a faulted and fractured anticlinal ridge

12. Diagram showing possible movement of ground water through a faulted and fractured anticlinal ridge bordered by a synclinal ridge

13. Plan view showing section lines for figures 12 and 14 and possible flow lines in the plane of the sandstone formation

14. Diagram showing possible movement of water along a vertical plane parallel to the strike of an anticlinal ridge

15. Block diagram showing possible circulation of water to the warm springs at Berkeley Springs, W. Va

16. Map showing geology and spring and well locations near Berkeley Springs, W. Va

17. Graphs showing water temperature of hot spring and stage of French Broad River at Hot Springs, N.C

18. Graphs showing temperature and discharge of Bolar Spring at Bolar, Va

19. Logs showing temperature for a cold-water well and temperature and fluid conductivity for a warm-water well

20. Temperature log for air-filled "dry" gas well (Pocahontas 21) near Minnehaha Springs, W. Va

21. Graph showing isotopes in Appalachian warm springs area waters

22. Graph showing dissolved silica and temperatures, Appalachian warm spring areas 


\section{TABLES}

1. Thermal gradients at wells producing warm or cold water

1. Thermal gradients at wells producing warm or cold water

3. Flow, temperature, and power output of thermal springs

4. Temperatures and selected analytical data for waters in Appalachian warm-spring areas

5. Saturation indexes and carbon-isotope ratios for waters in Appalachian warm-spring areas 


\title{
HYDROLOGY AND GEOCHEMISTRY OF THERMAL SPRINGS OF THE APPALACHIANS
}

\author{
By W. A. Ноbba, Jr., D. W. Fisher, F. J. Pearson, Jr., \\ and J. C. Chemerys
}

\begin{abstract}
ThermaI springs in nine areas in the Appalachians from Georgia to New York were studied in 1975 and 1976 using satellite imagery, Iocal well and spring data, and results of current and early studies by other investigators. AlI the springs investigated discharge from folded and faulted sandstone or carbonate rocks in valley areas. Where geologic structure is relatively uncomplicated, ground water discharging from thermal springs probably has circulated to great depths roughly parallel to the strike of the bedding and has moved upward rapidly where a fault or faults cross the bedding. Hydrologic and chemical data suggest that most of the water discharging from warm springs in the Devonian Oriskany Sandstone is derived from recharge entering and circulating through that formation. The temperature of the thermal springs can be accounted for by "normal" geothermal heat flow if water circulates to minimum depths of 2501,600 meters along paths of sufficient Iength and contact area to absorb enough geothermal heat to raise the temperature of the water to that required to produce the given thermal springs. The discharge at springs where temperature fluctuates very little is primarily water from deep circulation. The discharge at springs where temperature fluctuates widely is warm water mixed with variable proportions of shallow-circulating cool water.

Observed temperatures of the warm springs range from $18^{\circ}$ to $41^{\circ} \mathrm{C}$; the highest chemical thermometer temperature is $84^{\circ} \mathrm{C}$. Agreement among observed, chalcedony, and cation temperatures of the warmest springs suggests reservoir temperatures of $30^{\circ}-50^{\circ} \mathrm{C}$. Dissolved helium, arsenic, potassium, and $\delta^{18} \mathrm{O}$ are considered as geothermal indicators. Tritium analyses are useá to calculate fractions of oId and modern components of mixed waters. Computer calculations of carbonate saturation indices show (1) considerable undersaturation in silica-rock warm spring waters and (2) carbonate equilibrium in the limestone and dolomite thermal waters. Better values of saturation indices are obtained when analyzed carbon dioxide rather than field $\mathrm{pH}$ is used in the computer input data. A method is described for adjusting $\delta^{13} \mathrm{C}$ to correct for carbon dioxide outgassing from water samples.
\end{abstract}

\section{INTRODUCTION}

\section{PURPOSE AND SCOPE}

The primary purpose of this study was to investigate the geologic and hydrologic setting and the physical and chemical character of several of the major warm springs in the Appalachians.
Investigative and analytical techniques in geochemistry, hydrology, and remote sensing have advanced significantly in recent decades, but few detailed studies of the thermal springs of the Appalachians were made during this time. By using new techniques and investigating the larger thermal springs, an attempt was made to identify common characteristics that would show the character of the geothermal systems of the region. The first part of this report, prepared by Hobba, describes the geologic and hydrologic setting of the springs; the second part, prepared by Fisher, Pearson, and Chemerys, discusses the geochemistry of the springs and inferences of thermalreservoir temperatures indicated by the chemical data.

The present study was a 1-year reconnaissance. Springs and wells were inventoried and water samples collected during the autumn of 1975 and the spring of 1976. Several cold springs and wells were also sampled to provide comparative data from which properties peculiar to the warm springs could be discerned. Complete hydrogeological and chemical data and descriptions of the methods of sample collection and analyses are given in Hobba, Chemerys, Fisher, and Pearson (1977).

\section{PREVIOUS STUDIES}

Various aspects of the warm springs in the Appalachian Mountains have been described in numerous scientific papers, some of which date from well back into the nineteenth century. In addition to descriptions of flow, temperature, and chemical character of the springs, many of the papers speculate as to the geologic structural setting and the origin and the depths of circulation of the waters. Most of the early inferences to depths of circulation of water were based on simplified assumptions of prevailing gradients and their effect on spring-discharge temperatures. Recent conceptual models, such as those of Lowell (1975), provide more 
realistic estimates of depths of circulation. Likewise, many of the earlier interpretations of geologic structure associated with the springs were based on field observations. Now, gross structural features may be revealed by remote sensing from satellites or highaltitude aircraft. Similarly, geochemical techniques were formerly very simple; recently techniques have been vastly improved so that water-rock reactions and chemical equilibria can be modeled and even age dating of water is possible. From this prespective the following paragraphs summarize the earlier papers most useful to the present study.

McCallie (1908) reported the chemical quality and discharge of Warm Springs, Ga. In a later paper, McCallie (1913, p. 13) inferred a depth of circulation of about $450 \mathrm{~m}$ on the basis of the discharge temperature, the mean annual air temperature, and an assumed "normal" geothermal gradient. Because of errors inherent in the simplified assumption, $450 \mathrm{~m}$ probably represents, at best, only a minimum depth of circulation. In an extensive study of Warm Springs and the surrounding area, Hewett and Crickmay $(1937$, p. 34 , 35 ) concluded that the water emerging from the springs enters a bed in the lower part of the Hollis Quartzite on Pine Mountain, moves downdip to a depth of about $1,200 \mathrm{~m}$ where the bedding is offset by a fault, moves upward along the fault, and then moves updip along a second permeable bed near the top of the Hollis Quartzite to discharge where the bed crops out.

Keith (1904), Stose and Stose (1947), and Oriel (1950) generally agreed that the area surrounding Hot Springs, N.C., is faulted and may be described as a structural window. However, Trapp (1970) suggested that the structure is a graben rather than a window and stated (p. 28) that "A fault probably forms part of the artesian system supplying the thermal springs at Hot Springs." Stose and Stose (1947, p. 644) concluded that the spring water circulates to a depth of about $1,500 \mathrm{~m}$ and discharges along a nearly vertical fault.

Rogers (1884) and Reeves (1932) describe the warm springs of Virginia. Rogers (1884, p. 577-597) observed that many of the warm springs are on the axes of anticlines and suggested that water enters the rocks in the anticlinal ridges and sinks along joints and fissures until it reaches a permeable bed along which it then rises to discharge at the outcrop in an adjacent valley. Reeves (1932, p. 28) suggested that water enters a permeable bed at a relatively high altitude on the crest or limb of one anticline and travels along this bed through a syncline to an outcrop at a lower altitude in another anticline. According to Reeves (1932, p. 26), some anticlines are broken by thrust faults, but most of the springs in the region are not on faults, and hence few are fed by water rising along fault planes or associ- ated fissures. Rogers and Reeves both postulated, because of similarity in chemical composition, that the water from the warm springs is of the same meteoric origin as that from the cold springs.

More recently Kulander and Dean (1972) studied gravity and structure across Browns Mountain, Wills Mountain, and Warm Springs anticlines. They reported that the rocks beneath Browns Mountain "anticlinorium" are cut by at least seven faults, most of which are interpreted as thrust faults dipping to the east. Displacement along a thrust fault cropping out just west of Minnehaha Springs is about $450 \mathrm{~m}$. A similar structure is proposed for the rocks beneath Warm Springs anticline.

Heltz and Sinex (1974) studied the chemical equilibria in the thermal spring waters of Virginia and reported that; (1) neither concentration of dissolved constituents nor water temperature has changed in the past 140 years; (2) the waters with temperatures below $25^{\circ} \mathrm{C}$ are undersaturated with respect to calcite and dolomite, whereas those above $25^{\circ} \mathrm{C}$ are in equilibrium with calcite and dolomite; and (3) the waters with temperatures less than $25^{\circ} \mathrm{C}$ are probably mixtures of warm and cool ground water.

Costain (1976) recently evaluated the geothermalresource potential in the vicinity of the Warm Springs anticline in Bath and Allegheny Counties, Va. He $(1976$, p. 40) concluded that meteoric water percolates downward through the ridges, southeast of the anticline, to a depth of about $3 \mathrm{~km}$; and that it moves from there along thrust faults that dip gently southeastward. The water is assumed to rise relatively rapidly along high-angle cross-faults which intersect one or more of the thrust faults at depth.

Hobba, Friel, and Chisholm (1972), in a description of the water resources of the Potomac River basin in West Virginia, showed with a triangular diagram how the chemical composition of the water discharging from Berkeley Springs varies with time; the spring water probably is a mixture of (1) cold water from near-surface sandstone and carbonate rocks and (2) warm sodium chloride water from deeper aquifers. Assuming steady-state conditions, a geothermal gradient of $21.6^{\circ} \mathrm{C} / \mathrm{km}$, and sufficient length and area of flow path to intercept all the geothermal heat flow, the water is moving upward from a depth of about $530 \mathrm{~m}$.

Lowell $(1975$, p. 355,356$)$, using a mathematical model, computed depths of circulation of $1,100 \mathrm{~m}$ for Warm Springs, Ga., 1,300 $\mathrm{m}$ for Warm Sulphur Springs, Va., and $1,700 \mathrm{~m}$ for Hot Springs, N. C. Lowell's model consists of two vertical fractures and an intervening horizontal conduit. In the model, he considers flow rates and minimum contact areas required to transfer geothermal heat flow (in a region of so- 
called "normal" geothermal gradient) to the water and also conduction losses as the water ascends to land surface.

The spring at Lebanon Warm Spring, N. Y., has not been investigated in detail. However, as early as 1843, W. W. Mather observed that the spring was at or near the contact of limestone and slate beds. Mather (1843, p. 106) also observed " *** traces of a fault, and of much derangement of the strata in the immediate neighborhood."

Similarly, little has been done on the Perry County Warm Springs in Pennsylvania. Early mention of the springs was made by Claypole, in 1855 (p. 348), who suggested that they may derive their water from surface streams. Little scientific study was done until the recent study by Weinman (1976), who reports that the springs are at the intersection of two lineaments he observed on ERTS (Earth Resources Technology Satellite) color composite imagery.

\section{ACKNOWLEDGMENTS}

Many people provided valuable assistance during various phases of the investigation. J. B. Foster and R. L. Wait made geophysical logs of wells. T. K. Ellis and G. Goold provided records of wells in Virginia and New York, respectively. R. Rogers, P. Gentry, R. Taylor, and J. D. Henry monitored spring temperatures in Virginia, North Carolina, and West Virginia, respectively. S. M. Pickering, Jr., R. P. Lowell, J. K. Costain, and B. Weinman provided helpful discussions and information regarding thermal springs in Georgia, New York, Virginia, and Pennsylvania, respectively. Personnel of the Pennsylvania Geological Survey supplied well information from their files. A. H. Truesdell helped greatly with advice on the interpretation of the geochemistry of hot-water systems and of various geothermometers. L. N. Plummer provided valuable assistance in devising computer programming techniques for the calculated carbonate geochemistry data in this report. F. W. Trainer and F. H. Olmsted furnished guidance and support throughout the study; Olmsted assisted in combining two separate manuscripts on hydrology and geochemistry into the present paper. Finally, the cooperation of all the individuals who permitted access to their property, wells, and springs is particularly appreciated.

\section{HISTORICAL BACKGROUND}

Many of the warm springs included in our investigation have long and interesting histories. While George Washington was surveying for Lord Fairfax in 1748 he bathed in "ye fam'd warm springs" at the present site of Berkeley Springs, W. Va. Later Lord Fairfax granted the springs and 50 acres (20 ha) to what was then the colony of Virginia, with the stipulation that the waters were "to be forever free to the public for the welfare of suffering humanity." Even before Washington visited these springs the Indians used the springs for bathing, as they did those at Warm Springs, Ga. Later the Georgia springs were to be used by President Franklin D. Roosevelt in treatment of his polio.

After discovery of the warm springs by white men, development soon took place. At some springs elaborate pools and hotels were built to accommodate visitors seeking the healing and medicinal powers claimed for the warm waters. Many of these spas flourished in the late 1700 's and early 1800 's when there was no treatment or cure available for ailments such as rheumatism, arthritis, polio, diabetes, gout, stomach disorders, or kidney stones. The hotels and spas built at many of the springs continue to flourish as resorts today, as does the Homestead Hotel at Hot Springs, Va. (fig. 1). Some like the Warm Springs Hospital at Warm Springs, Ga., continue to flourish as hospitals. Many of the buildings at some spas fell into disrepair, were destroyed, or were converted to other uses, but some warm springs, not included in this study, still sustain prosperous resorts such as those at White Sulphur Springs and Capon Springs, W. Va.

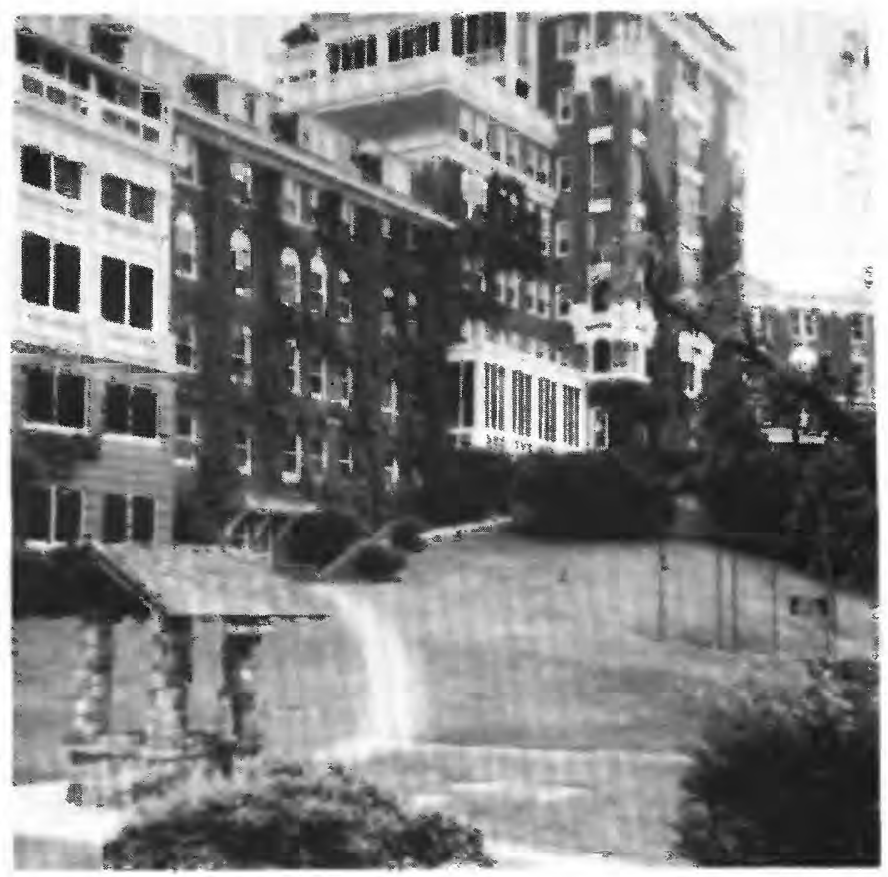

Figure 1.-Homestead Hotel and Hot Sulphur Spring (foreground) at Hot Springs, Va. 


\section{GEOLOGIC AND HYDROLOGIC SETTING}

$$
\text { By W. A. Hobba, Jr. }
$$

\section{GENERAL DESCRIPTION OF THE SPRINGS}

The part of the eastern United States covered by this report extends from western Georgia to eastern New York. This area lies primarily in the Valley and Ridge province, which is characterized by a series of northeast-trending valleys and ridges. The maximum altitudes in the central part of this area (West Virginia, Virginia, and North Carolina) range from 1,200 to $1,400 \mathrm{~m}$ above sea level. The valley floors, where the warm springs commonly emerge, are at elevations of $670-700 \mathrm{~m}$ in the Virginias and at about 400 $\mathrm{m}$ in North Carolina. Toward the north and south the maximum altitudes decrease; in New York the maximum altitude is about $700 \mathrm{~m}$ and the valleys are at about $210 \mathrm{~m}$; in Georgia the maximum altitude is about $430 \mathrm{~m}$ and the valleys are at about $240 \mathrm{~m}$.

The thermal springs are generally at the valley margins or a short distance up the valley walls. One spring in North Carolina discharges upward through about $4.5 \mathrm{~m}$ of alluvium on the valley flat. Most of the others discharge directly from bedrock or through weathered residuum. Most of the thermal springs are in or near small rural communities surrounded by forested hills and farmed valleys. Growths of green algae and water cress are common in the warm springs and their runoff channels.

Temperatures of the spring waters range from $17.7^{\circ}$ to $41.7^{\circ} \mathrm{C}$. On cool days vapor clouds commonly form over the warmer springs and their runoff channels. Recent discharges measured at the springs range from 4 to $293 \mathrm{~L} / \mathrm{s}$; these are probably minimum discharges because at some sites leakage occurs around the measuring site through the alluvium or other unconsolidated material.

\section{PHYSICAL SETTING}

\section{GEOLOGY AND TOPOGRAPHY}

Most of the warm springs in the eastern United States are in the folded and faulted Valley and Ridge province of the Appalachian Mountains. Ten of these spring groups having relatively large yields and temperatures above $15^{\circ} \mathrm{C}$ were selected for this study. These spring groups comprise: Lebanon Springs, N.Y.; Perry County Warm Springs, Pa.; Berkeley Springs and Minnehaha Springs, W. Va.; Bolar Spring, Hot Springs, Warm Springs, and Falling Spring, Va.; Hot Springs, N.C.; and Warm Springs, Ga. Although many of the springs are widely separated geographically, similar geology and topography characterize each of the warm-spring areas. All the springs discharge from sandstone or limestone; and, with two exceptions, every spring is in a valley on the crest or flank of an anticline. (The exceptions are Lebanon Spring in New York and Hot Springs in North Carolina. They discharge from faulted limestones of complex structure, Lebanon Spring on a hillside and Hot Springs in a synclinal valley that has been described by some writers as a graben and by others as a horst.) As early as 1840 , W. B. Rogers observed that 46 of 56 thermal springs he studied in the Appalachians of Virginia and West Virignia are on or near anticlinal axes. Regarding the thermal springs of Virginia, he (Rogers, 1843, p. 331) concluded that, in general, the springs "issue from the lines of anticlinal axes, or from points very near such lines."

Topography, lithology, and structure are important factors in the occurrence and character of thermal springs in the Appalachian Mountains. Topography controls potentiometric head relations that make possible deep circulation of the water and its return to the surface. The large yields of some of the thermal springs, and the fact that the water retains appreciable heat until it reaches the surface, indicate the presence of effective flow conduits. These conduits probably are related to both lithology and structure. Both the sandstone and the limestone of this region can provide the permeability required to permit the rapid upward migration of warm water-sandstone through fractures and intergranular openings, limestone through solution-widened fractures. In the more "plastic" or less competent shale, the weight of the overlying rock may lead to decrease in permeability with depth; under this condition the upward movement of warm water is slow, and the water has an opportunity to cool as it moves upward just as it warmed when it moved downward. The depth of circulation in shale is not known; the scarcity of thermal springs in shale may reflect either lack of deep conduits in this type of rock or a tendency for the water to cool after rising from depth, as already suggested. The effect of structure on occurrence of the thermal springs is considered in the next section of this report.

\section{ROCK STRUCTURE}

The occurrence of warm springs in the eastern United States suggests a relationship between the structure of the rocks and the deep flow systems that develop and produce the warm springs. As noted earlier, the warm springs are typically on the crests or limbs of anticlines. Several structural features in these settings favor vertical permeability: openings along bedding planes, open tension fractures, and open faults and other fractures common to folded rocks. Interest- 
ingly, thermal springs are unknown along faults in the Appalachian Plateaus province where the rocks are relatively flat lying and faulted and the relief is high. Similarly, at many localities in the Valley and Ridge province the rocks are folded, faulted, and fractured, topographic relief is great, and the same geologic formations from which warm springs issue at other localities are present, but all the springs are cold. Apparently deep circulation paths have not been developed at these sites. The warm springs are found where deeper circulation paths have been developed preferentially to the shallower circulation paths.

It is relatively easy to identify the probable dip of bedding planes and the general orientation of tension fractures, but it is more difficult to identify faults. However, satellite imagery is helpful in identifying linear features, some of which represent faults or fracture zones. Some faults, especially those that cross the strike of the bedding of the rocks, stand out well on ERTS imagery. Figure 2 shows a NW-SE trending fault passing through Webster Springs, Huntersville, and Minnehaha Springs, W. Va., and through Warm Springs, Va. This fault gives rise to a warm spring at Huntersville and perhaps to two other warm springs just northwest of Lexington, Va. In fact, a warm spring occurs each place the fault cuts the sandstonelimestone aquifer formed by the Oriskany Sandstone and Helderberg Group. The apparent northwest end of

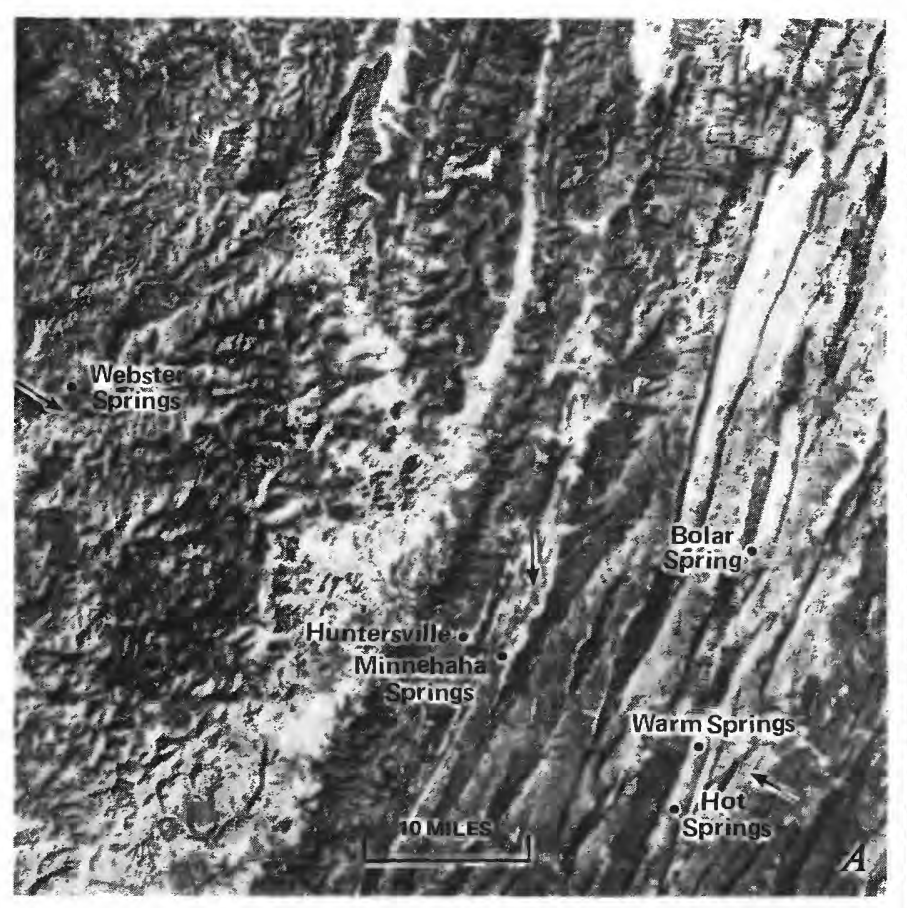

FIGURE 2.- Satellite images of thermal spring areas in $A$, Virginia and West Virginia, $B$, Georgia, and $C$, New York. (Lettered arrows indicate lineaments.) the fault lies near Webster Springs, where it may yield the salty water observed in springs and wells. (One salty cold spring discharging in the bed of the Elk River was reported by Price and others (1936, p. 101) to contain about $4,000 \mathrm{mg} / \mathrm{L}$ chloride. During this investigation an attempt was made to sample the same spring but it could not be found. However, a well in Webster Springs, sampled during the present study,
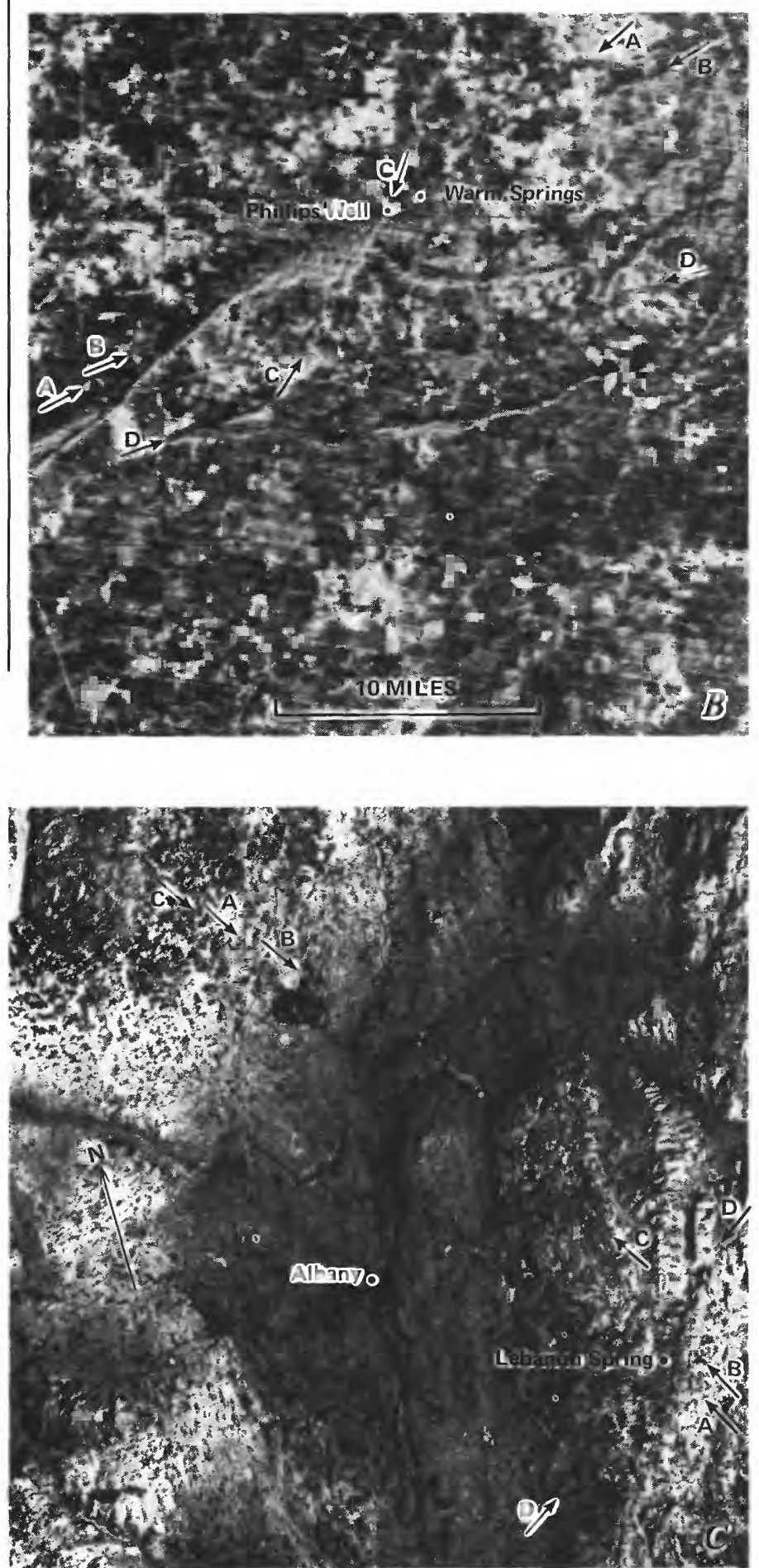
contained $3,240 \mathrm{mg} / \mathrm{L}$ chloride.) What appears to be this same fault is also apparent on the SLAR (sidelooking airborne radar) image (fig. 3). Although the SLAR image is much sharper and at a larger scale than the ERTS image, faults are more readily apparent on the ERTS image. However, the offset of ridges by faults is more apparent on the SLAR image.

In the Minnehaha Springs area, hydrologic data can be used to aid in the interpretation of fault data obtained from the imagery. Figure 4 shows the geology of the area around Minnehaha Springs. Well 404, $14 \mathrm{~m}$ deep, penetrated only sandstone. The water had a specific conductance of $140 \mu \mathrm{mhos} / \mathrm{cm}$ and a $\mathrm{pH}$ of 5.8 ; both these parameters are typical of water from the sandstone. According to the geologic map, well 405 should be in limestone, but the well is $26 \mathrm{~m}$ deep and

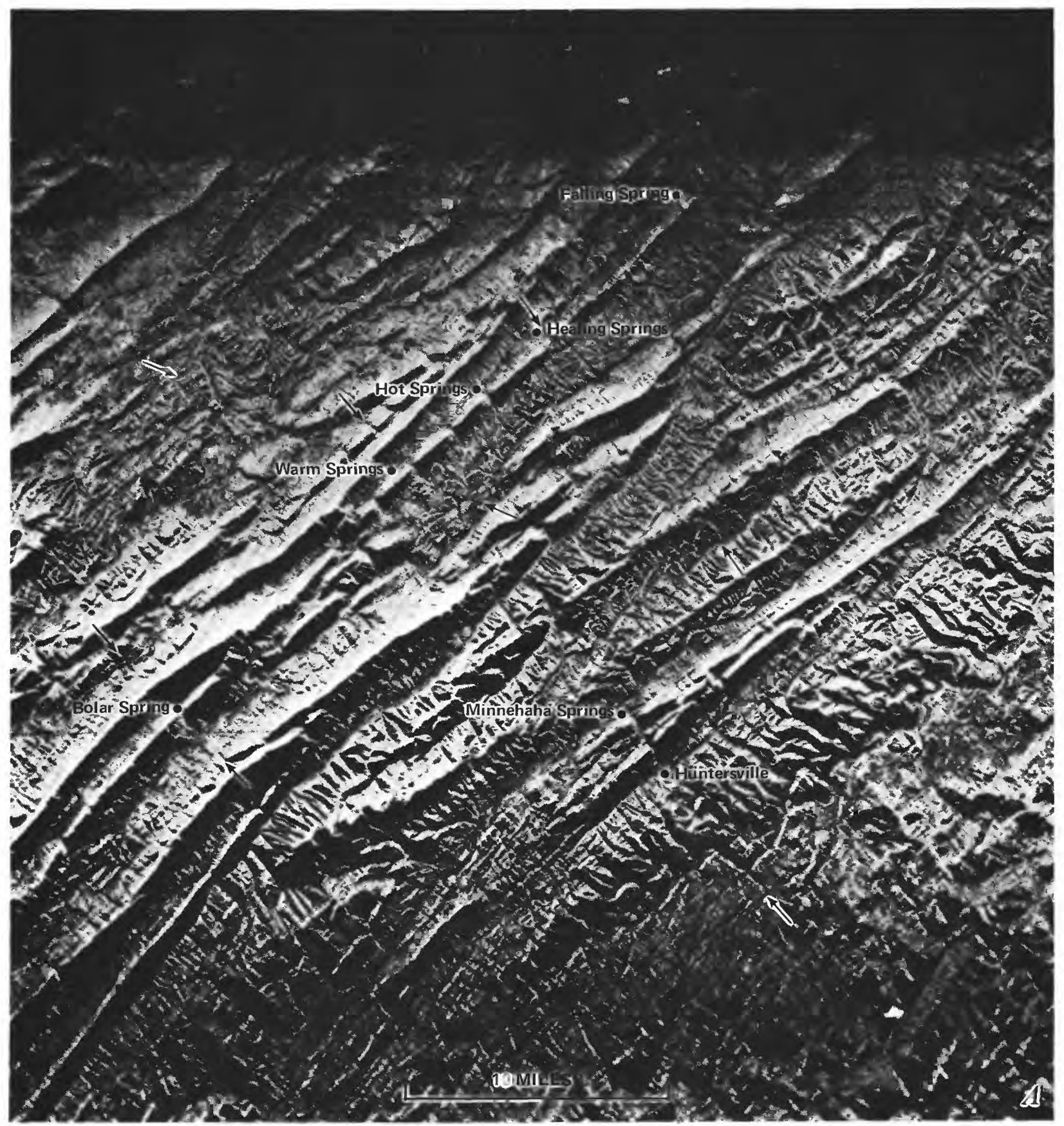

FIGURE 3.-Side-looking radar images showing prominent lineaments and thermal springs and wells in $A$, Virginia and West Virginia, and $B$, Georgia. (Lettered arrows indicate lineaments.) 
yields water with a specific conductance of $80 \mu \mathrm{mhos} /$ $\mathrm{cm}$ and a $\mathrm{pH}$ of 4.9 ; the water quality indicates that this well also taps the sandstone formation. If both wells tap sandstone, the northwest-trending fault passes south of well 405 and the northern block is downdropped relative to the southern block, thus displacing the outcrop of the sandstone on the northern block westward.

Figure 5 represents an interpretation by Kulander and Dean (1972) of the geology in a vertical section parallel to this fault and about one mile north of it (see fig. 6). Their section is based on seismic, well, gravity, and magnetic data. The warm springs at Minnehaha Springs and at Huntersville both occur at points in the outcrop of the Oriskany Sandstone where the fault parallel to the line of the section intersects northerly trending faults. The northerly trending fault at Huntersville was mapped by Kulander and Dean (1972). Another fault passing directly through Minnehaha Springs is visible on the ERTS image and was mapped by the authors (fig. 2). It trends about N. $3^{\circ} \mathrm{W}$. and extends about $74 \mathrm{~km}$. A second fault just east of Minnehaha Springs strikes about N. $3^{\circ} \mathrm{E}$. It appears to be about $105 \mathrm{~km}$ long, reaching $68 \mathrm{~km}$ south of Natural Well, Va. The latter fault was found in the field at Ruckman Spring (a large cold spring, 408 fig. 4) prior to observing it on the ERTS imagery. These observations of the occurrence of springs along faults or lineaments are in agreement with those of Weinman (1976), who pointed out that the warm spring in Perry County, $\mathrm{Pa}$, lies at the intersection of two lineaments observed on color-composite ERTS imagery. He also found that the warm water at the spring is detectable on low- altitude thermal imagery. Werner and Medville (1975) pointed out that in West Virginia both warm and cold springs occur on lineaments or at the intersections of lineaments as observed on ERTS imagery.

The lithology and structure at Minnehaha Springs, Berkeley Springs, and Perry County Warm Springs are very similar (fig. 7): each group of springs is in a valley and discharges from the Oriskany Sandstone on the east flank of an anticline. Weinman (1976) mapped two lineaments in the vicinity of Perry County Warm Springs which intersect at the springs just as similar lineaments do at Minnehaha Springs. At Berkeley Springs no intersecting pair of lineaments was observed on the satellite imagery; however, a single subtle but extensive lineament was observed that extends from Berkeley Springs northwestward across Pennsylvania along much of the course of the Allegheny River to the southeastern shore of Lake Erie. The southeastern extent of this lineament is not well defined, but it may follow part of the lower course of the Potomac River.

The lithology and structure at Warm Springs, Ga., are somewhat similar to that at warm springs in the Oriskany Sandstone in West Virginia and Pennsylvania. The warm springs in Georgia, in a valley on the northwest flank of an anticline formed by the Hollis Quartzite, discharge at the contact of the quartzite (which forms Pine Mountain) and the overlying Manchester Schist. Both schist and quartzite are cut by faults and lineaments (see arrows in fig. 2). One lineament passes through the large cold spring southeast of Warm Springs; another one passes northeast through a $73-\mathrm{m}$ well which produces warm water. What may be a

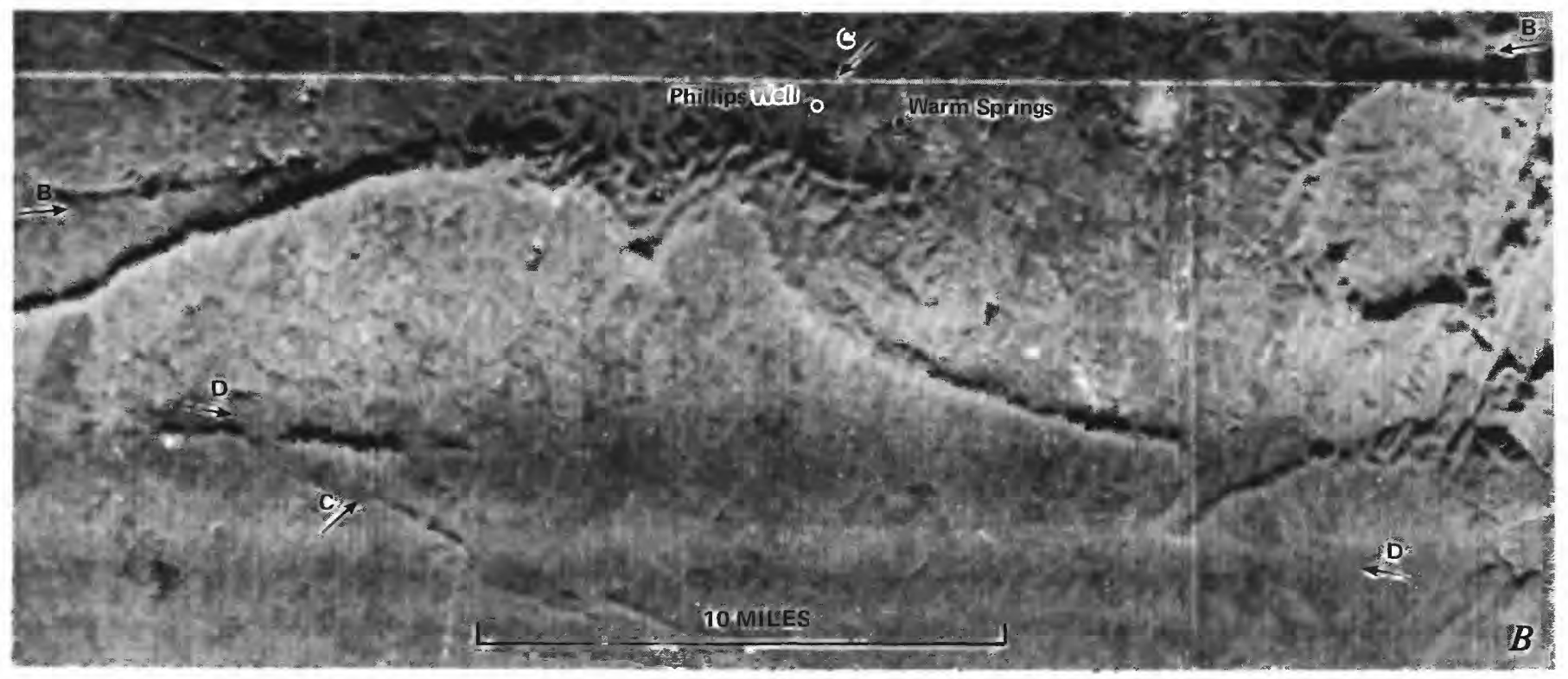

Figure 3.-Continued. 

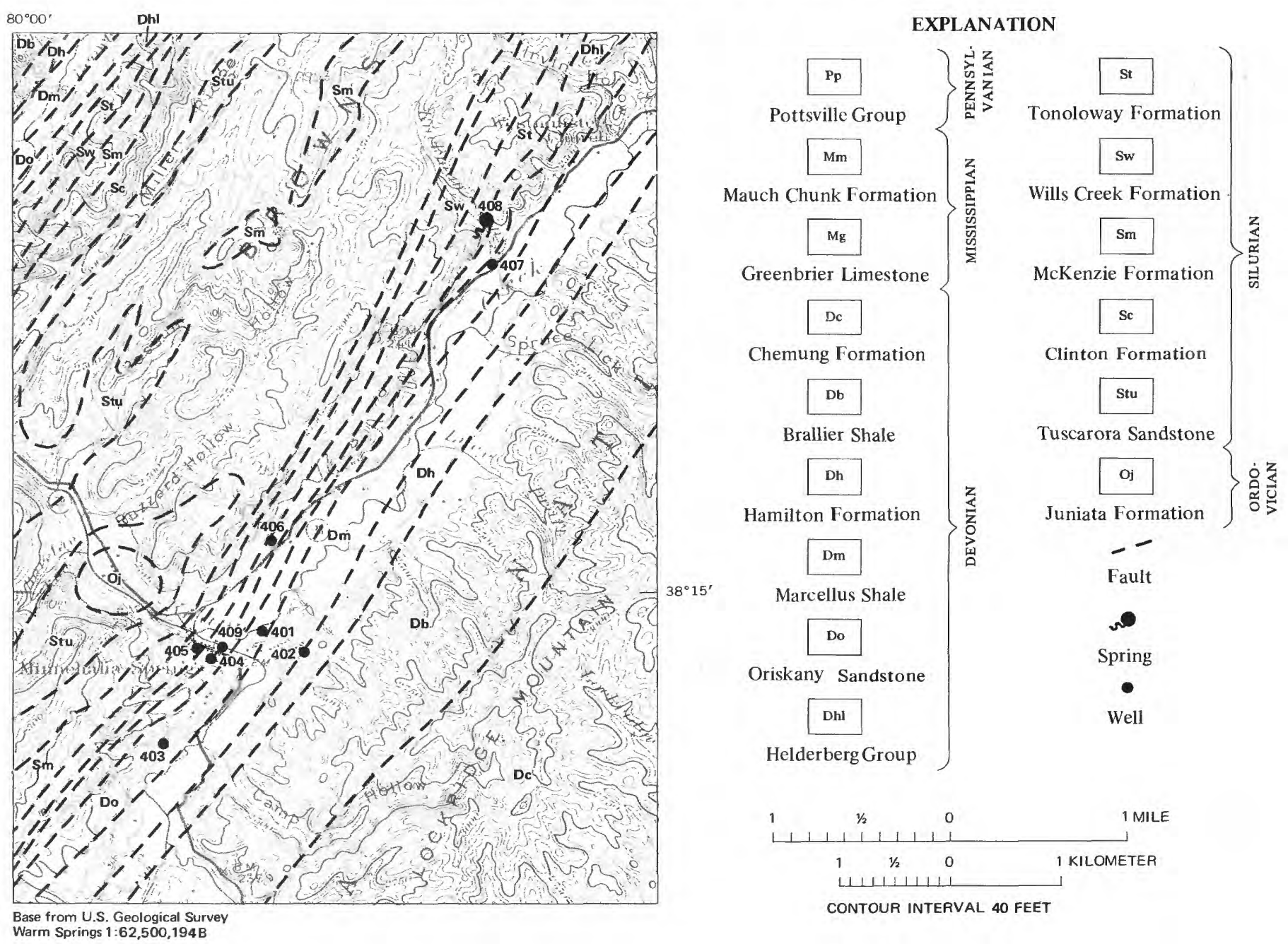

FiguRE 4.-Geology, spring, and well locations in Minnehaha Springs area, West Virginia.

third lineament strikes eastward and passes close to the warm spring.

Many lineaments have been mapped in the warm springs area of Virginia by the authors. Most of the known warm springs in this area are on lineaments, observed on the satellite imagery (fig. 6). Dennison and Johnson (1971, p. 506) suggested that the thermal springs here may be related to Eocene volcanism or that they represent a still younger deep source of heat (magmatic). Regardless of whether intrusion has occurred, the combination of deep fracturing, the local geology, high relief and structure favors deep circulation of ground water here.

The lineaments mapped near Lebanon Springs, N. Y., stand out well on imagery with snowcover on the ground (fig. 2C). One prominent northwest-trending lineament passes through the spring, as does a lobate northeast-trending feature (not indicated) that may be structural.

The satellite imagery offers good evidence that the thermal springs occur in valleys where lineaments or faults cut steeply dipping beds of sandstone or limestone. Although many thermal springs occur on the crest or flanks of anticlines, the anticlinal structure itself is not the only factor contributing to their occurrence. The tension fractures that parallel the anticlinal axis and the dipping rocks are conducive to deep circulation parallel to the structure. However, vertical

FIGURE 5.-Cross section parallel to fault passing near Webster Springs and Minnehaha Springs, W.Va. and Warm Springs, Va. (Modified after Kulander and Dean, 1972. Approximate line of cross section is along lineament trending southeasterly from Huntersville to Warm Springs in fig. 6.) 


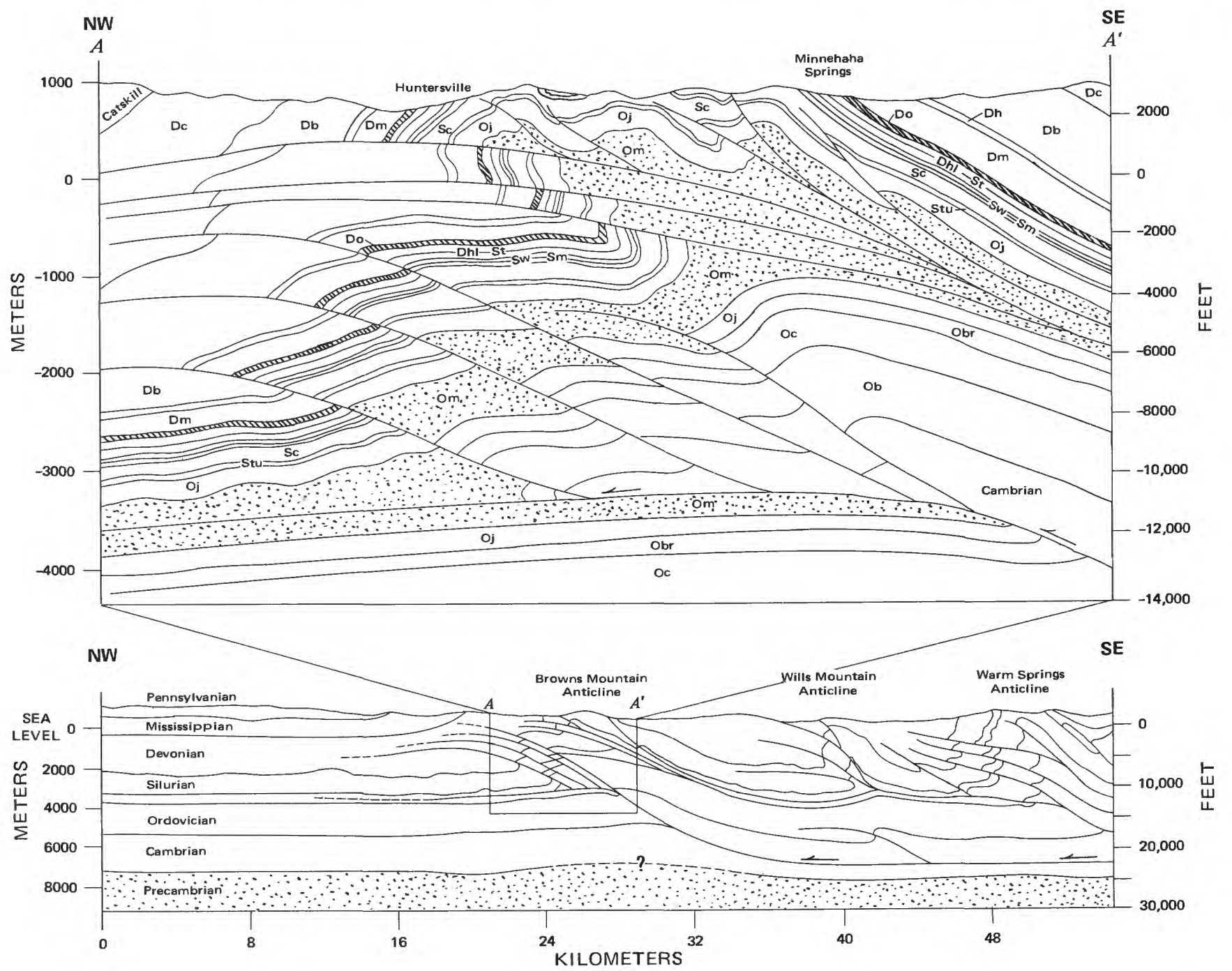

EXPLANATION

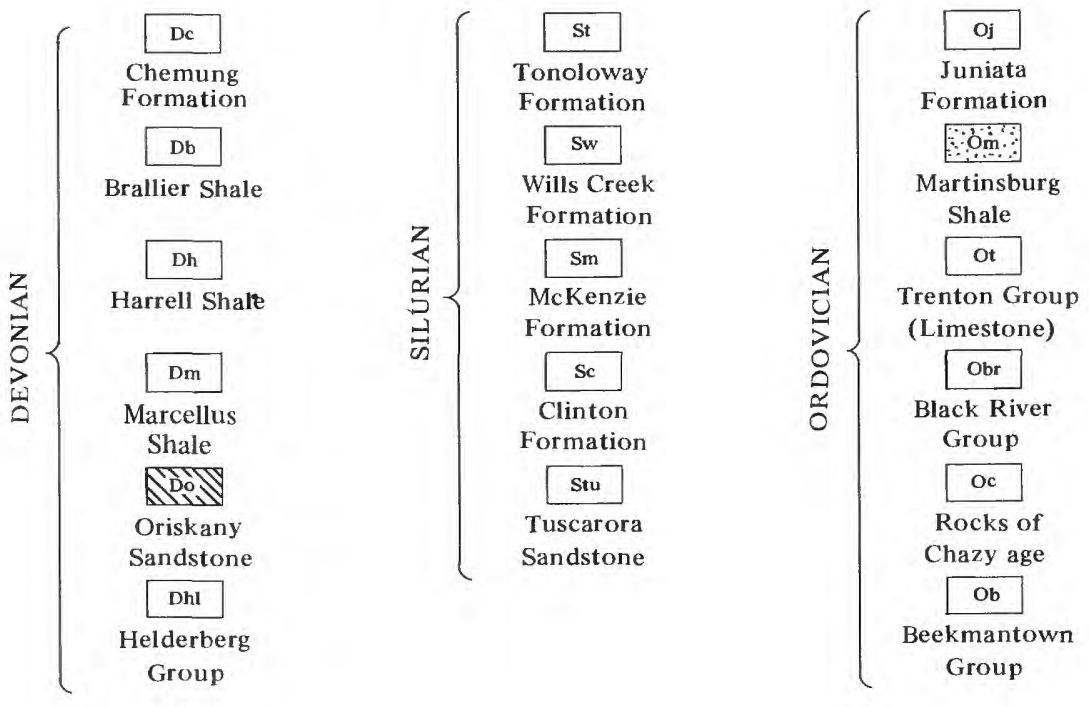




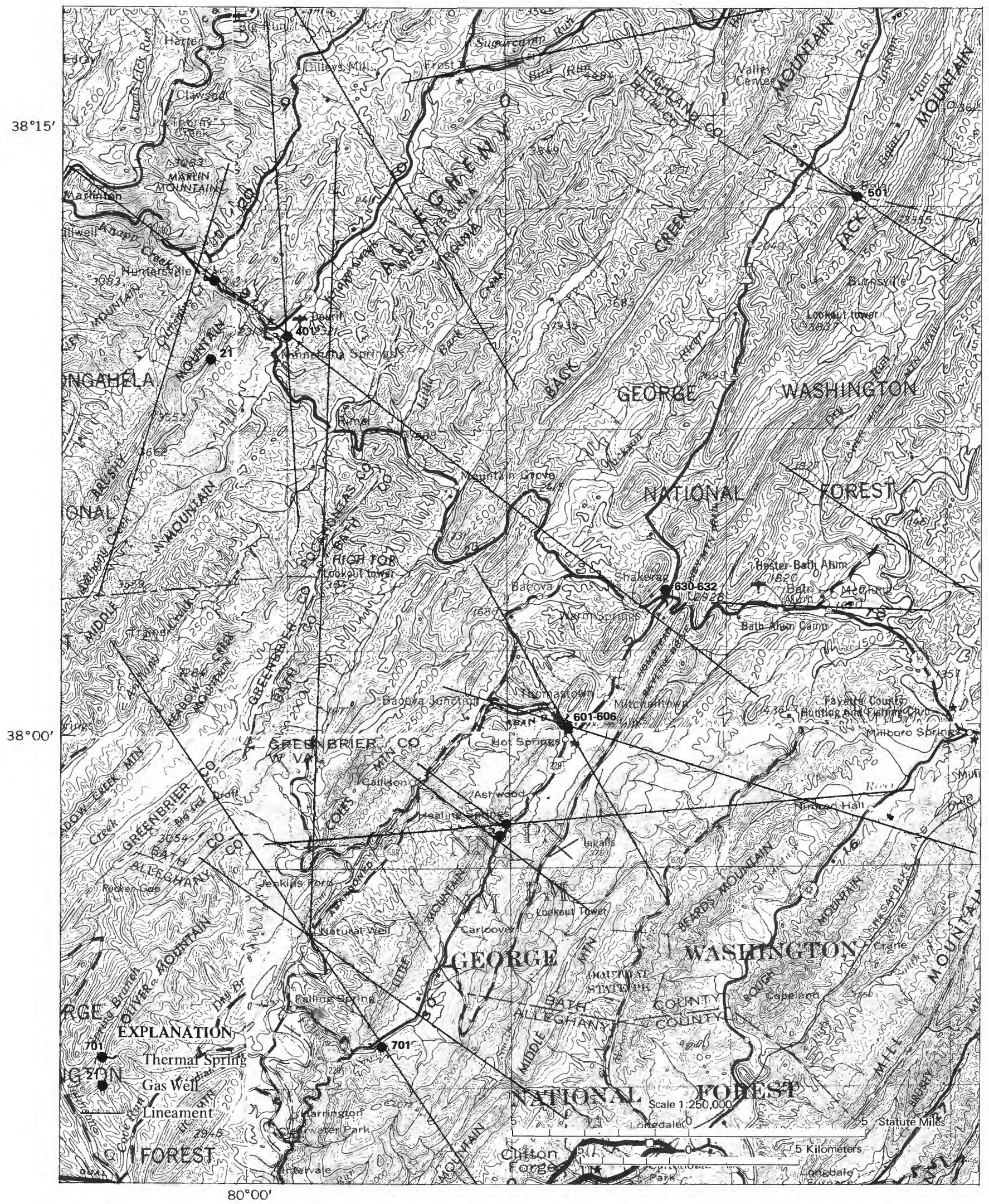

FIGURE 6.-Map showing lineaments and their relationship to thermal springs in Virginia and West Virginia. 


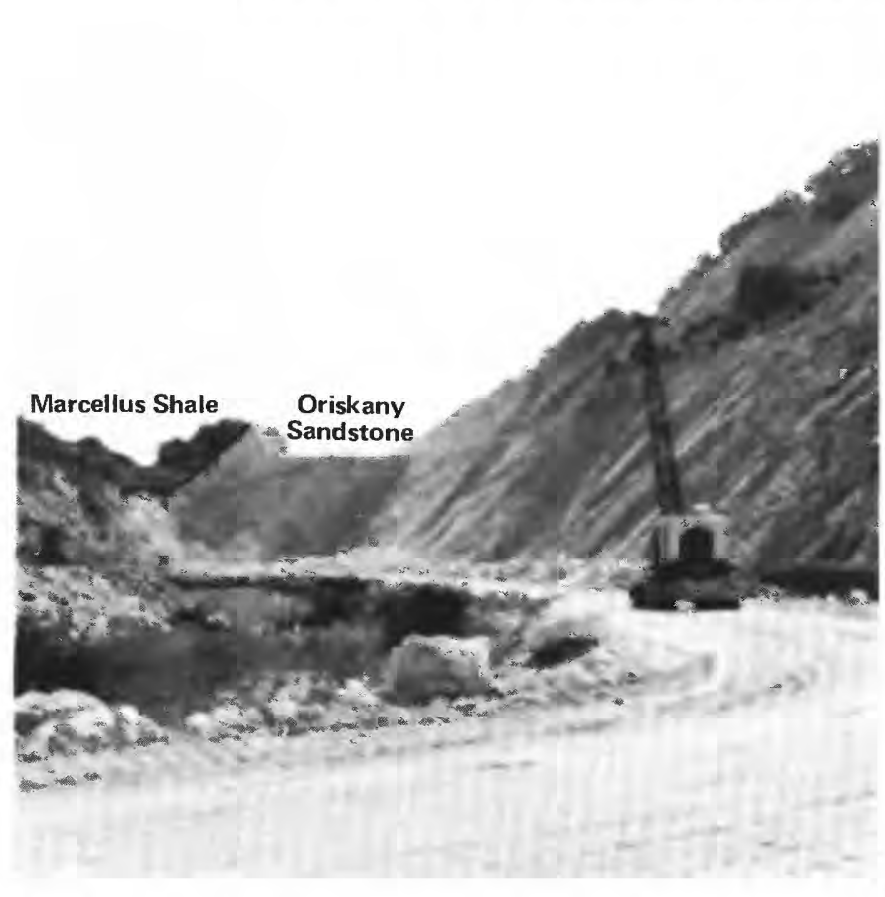

FIGURE 7.-Sandstone quarry looking southwest toward Berkeley Springs, W.Va. The spring is about $5 \mathrm{~km}$ from this site and discharges from the sandstone near the shale contact.

faults or lineaments, rock type, dip of the rock, and subsurface thrust faults may be the most important factors contributing to the occurrence of the warm springs. For example, a warm spring may be just as likely to develop on a monoclinal fold as it would on an anticlinal fold having similar lithology faults, topography, and hydraulic head. Table 3 , in a later section, summarizes the structural features at each of the thermal springs.

\section{HYDROLOGY}

\section{PROBABLE FLOW SYSTEMS}

All the springs investigated discharge in valleys whose adjacent ridges are underlain by fairly steeply dipping rocks. The warm springs in Georgia, West Virginia, and Pennsylvania are on the flanks of anticlines; in Virginia they are commonly near the crests of anticlines. It is of interest to consider likely hydrologic conditions where a warm spring is (1) in a valley near the crest of an anticline, (2) on the flank of a ridge formed by an anticline, or (3) on the flank of a ridge formed by a limb of an anticline.

The Virginia springs are in valleys at or near the crests of anticlines, where any bedding planes open to depth would be expected to permit flowlines of upward moving water to converge at the crest of the anticline. Figure 8 shows the theoretical flow lines of ground water in a homogenous, isotropic sand aquifer. Figure 9 shows inferred paths of ground-water movement

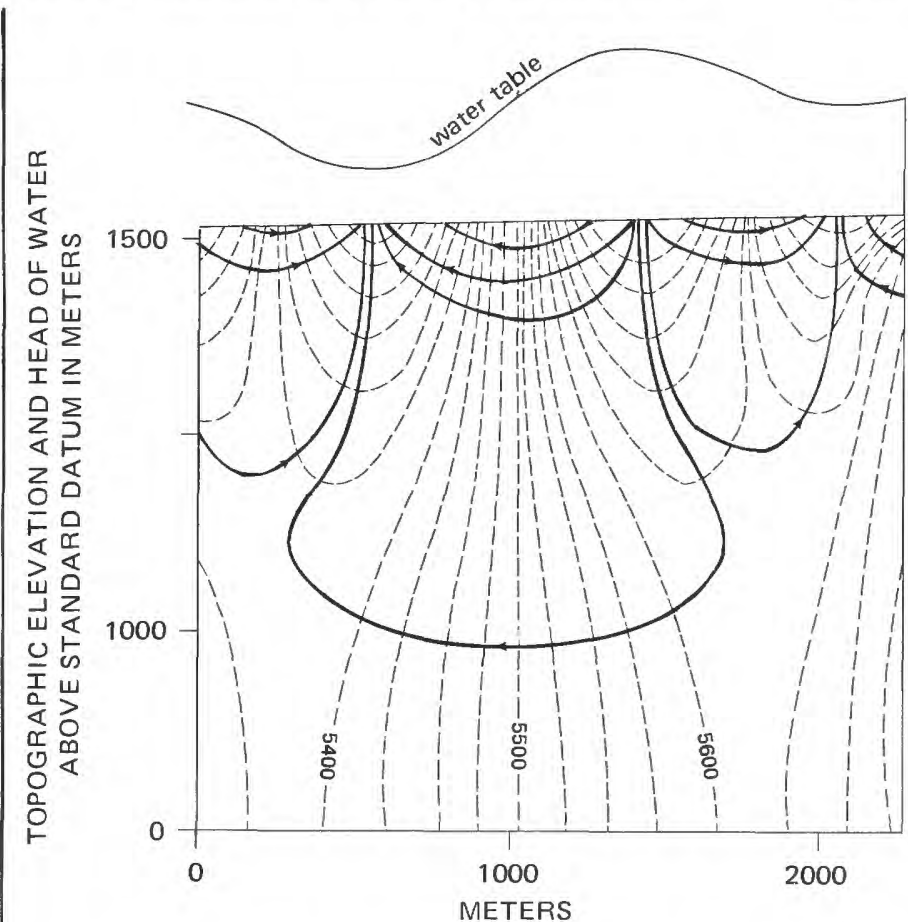

FigURE 8.-Theoretical movement of ground water through a homogeneous isotropic aquifer with an impermeable layer at 1,500 m. (After Toth, 1963.)

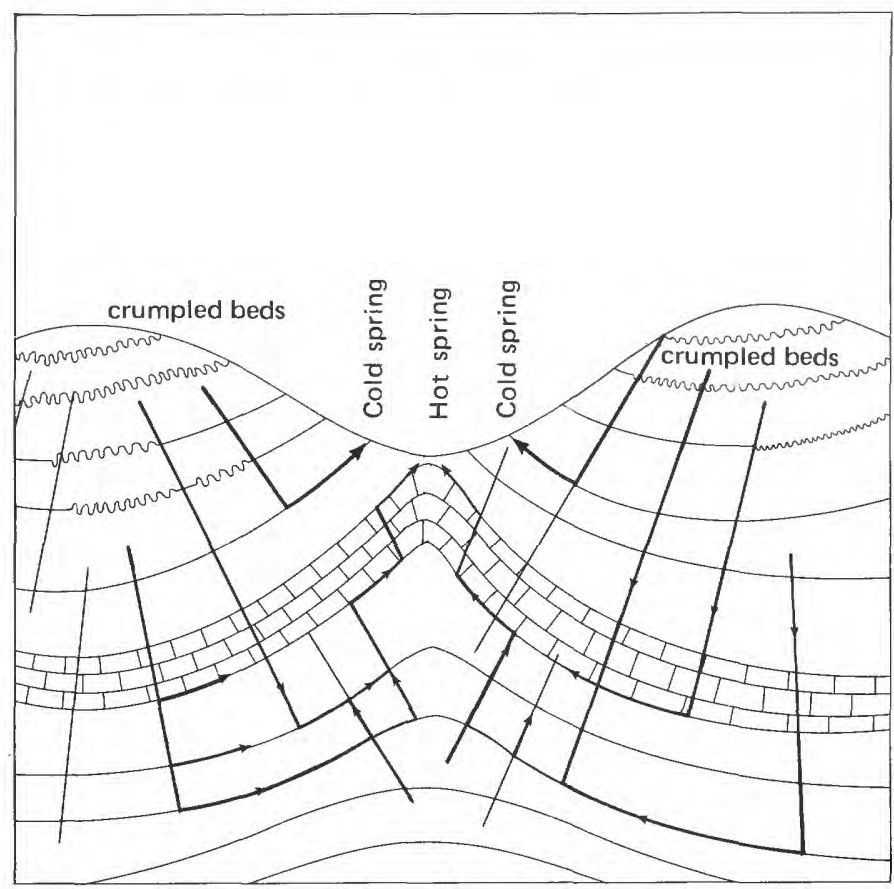

Figure 9.-Possible movement of ground water through a multilayered folded, faulted, and fractured aquifer such as those in Warm Springs Valley, Va. Much of the flow (not indicated by arrows) is into the figure and upward beneath the hot spring.

through the consolidated folded rocks in Virginia, in a plane normal to the strike of the rocks and at a place 
where the anticline crest forms a topographic low. To complete the picture, add low angle thrust faults at depth, a vertical fault or fracture at the spring, and possibly a fault or fracture in the plane of the cross section. Any such factors would contribute to the development of a system of conduits that permits ground-water circulation to great depths where head is sufficient to drive the system. The overall flow system may look something like that in figure 10 , but with much of the flow being into the plane of the figure along open tension fractures, bedding, or fault planes and upward beneath the spring.

The occurrence of springs along the crests of anticlines in valleys or in water gaps in the Valley and Ridge Province of Virginia and West Virginia has been noted by Rogers (1884), Price, Haskins, and McCue (1936), Hobba, Chemerys, Fisher, and Pearson (1977), and Clark, Chisholm, and Frye (1976). Clark, Chisholm, and Frye (1976) made statistical analyses of the yields of wells in various geologic and topographic situations. Working mainly with wells in limestone, they determined that yields along the axes of anticlines are significantly better than those along axes of synclines. Statistical tests by Siddiqui and Parizek (1972) showed that variation in structural control is not a significant factor in the productivity of wells not on fracture traces. The relatively high well yields reported by Clark, Chisholm, and Frye (1976) may reflect the presence of fractures that parallel the anticlinal axes. These fractures, along with deep vertical faults and perhaps deep horizontal thrust faults, could permit a deep flow system such as that in figure 9 to develop.

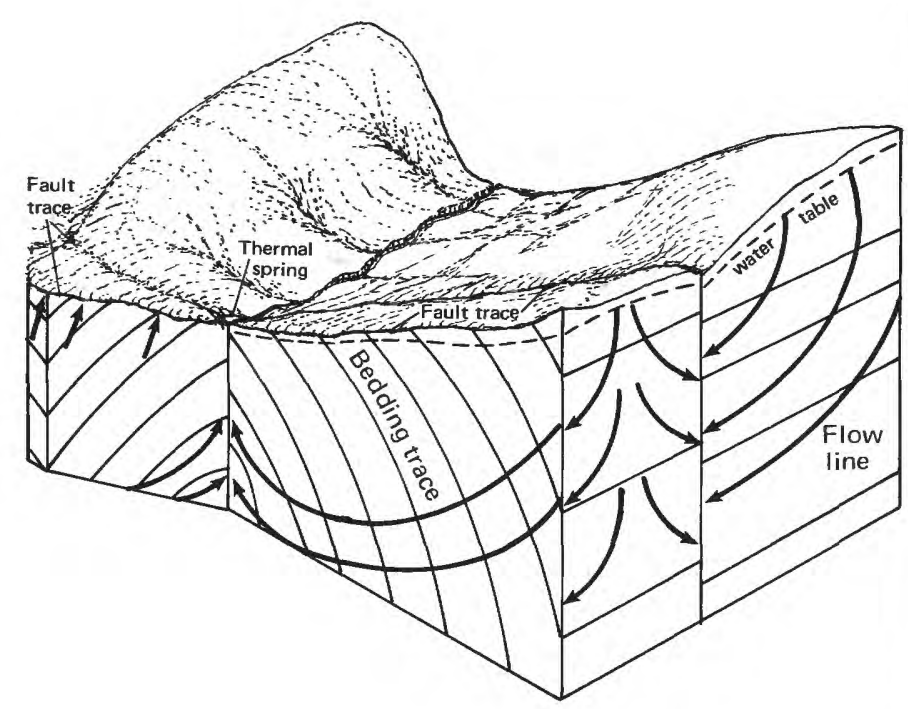

Figure 10.-Possible circulation of water to a warm spring located near the crest of an anticline at the intersection of two faults. Much of the flow is into the plane of the figure along open tension fractures, bedding, or fault planes and upward beneath the spring.
Predominantly deep circulation favors warm springs; predominantly shallow circulation favors cold springs.

The second type of flow system, which may develop on an anticline forming a topographic high, is represented by figure 11, which shows the flow pattern in a vertical plane normal to the strike of the rocks. Water moves down through the open fractures (joints and bedding-plane openings) to as great a depth as permeability and head allow, and then it returns to the land surface quickly along a fault or through other fractures. It seems unlikely, because of the generally short distances between the crest of the ridge and the warm spring, that a system like this would be capable of developing deep enough circulation to produce a warm spring (fig. 11). However, theoretical computations by Toth (1963) for a homogenous isotropic aquifer with an impermeable boundary at $1,500 \mathrm{~m}$ depth suggest that circulation to a depth of about $700 \mathrm{~m}$ is possible (fig. 8). His model roughly approximates the situation at some of the warm springs. Although circulation to this depth is sufficient to produce some of the moderately warm springs, it is insufficient to produce the warmest springs.

Figure 12 depicts the third type of geologic setting common at some of the warm springs. Here a ridge is formed by the flank of an anticline. The warm springs discharge from a sandstone unit underlain by carbon-

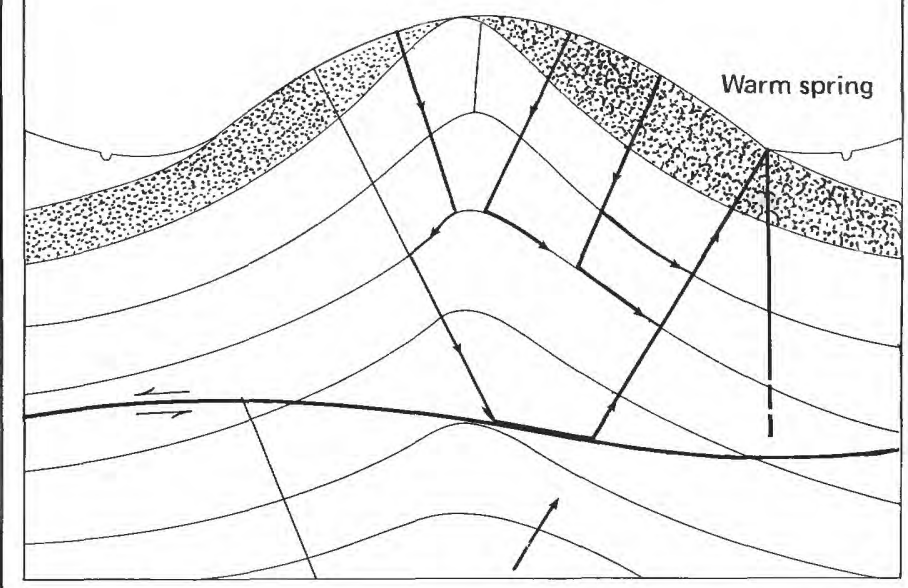

Figure 11.-Possible movement of ground water through a faulted and fractured anticlinal ridge bordered by a synclinal ridge. Aquifer has impermeable boundary at 1,500 $\mathrm{m}$ depth. Flow pattern is in a vertical plane normal to the strike of the rocks. 


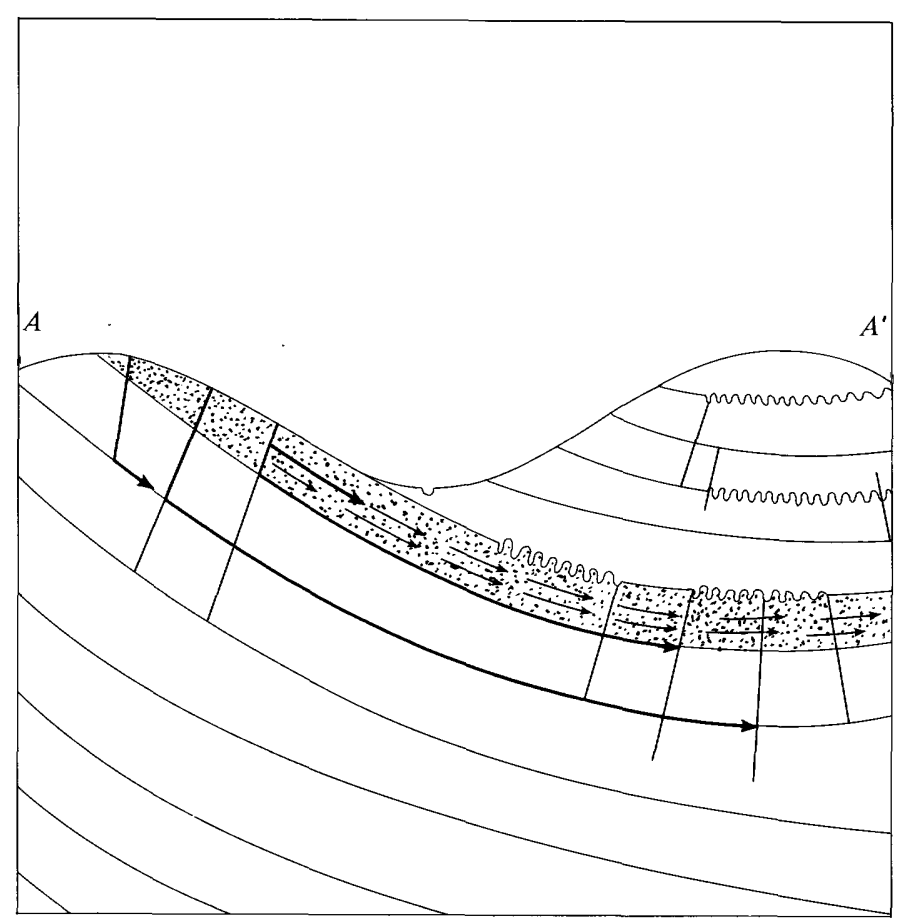

Figure 12.-Possible movement of ground water through a faulted and fractured anticlinal ridge bordered by a synclinal ridge. A ridge is formed by a flank of the anticline so that the water may flow by way of two routes-along a vertical fracture normal to $A-A^{\prime}$ and along the aquifer shown by the stippled pattern, in the plane of the cross section.

ate rocks and overlain by shale and siltstone. Water enters the ground and may flow to the spring by way of two routes or flow systems: The one indicated by the arrows in figures 12 and 13 shows the flow to be almost entirely within the plane of the sandstone formation. Figure 14 shows recharge and movement to the spring along a vertical fracture approximately normal to the line of $\mathrm{A}-\mathrm{A}^{\prime}$ (The lines of the sections in figures 12 and 14 are shown in figure 13.) This type of setting exists at the Warm Spring in Georgia and in West Virginia and Pennsylvania. A significant amount of hydrologic data is available in the vicinity of the warm spring at Berkeley Springs, W.Va. The situation is depicted in figure 15, and the data suggest that the flow system shown in figures 12 and 13 could be operating there with a small amount of water being added from the formations above or below the sandstone. Similar flow systems may be operating at the Perry County Warm Springs and at Minnehaha Springs.

\section{SELECTED FLOW SYSTEMS}

Figures 15 and 16 show the warm spring at Berkeley Springs and the wells along the contact of the shale and sandstone along the ridge that trends southwest from the spring. The water table in figure 15 is based on reported and observed water-level data from the

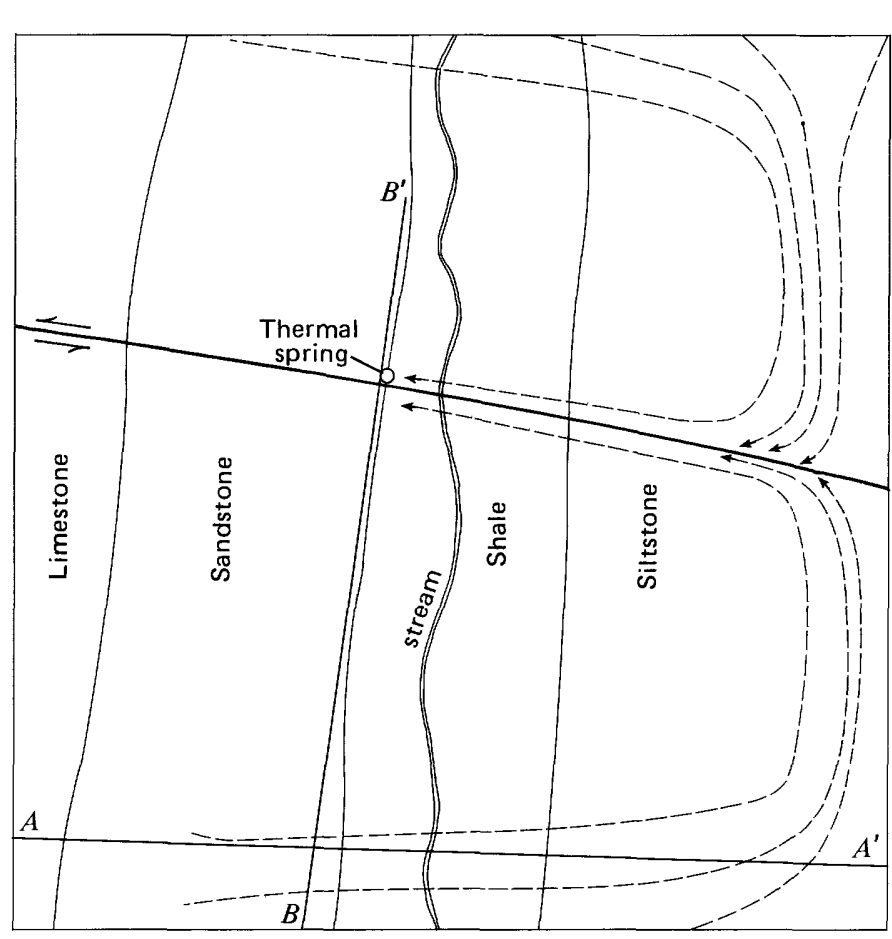

Figure 13.-Plan view showing section lines for figures 12 and 14 and possible flow lines in the plane of the sandstone formation.

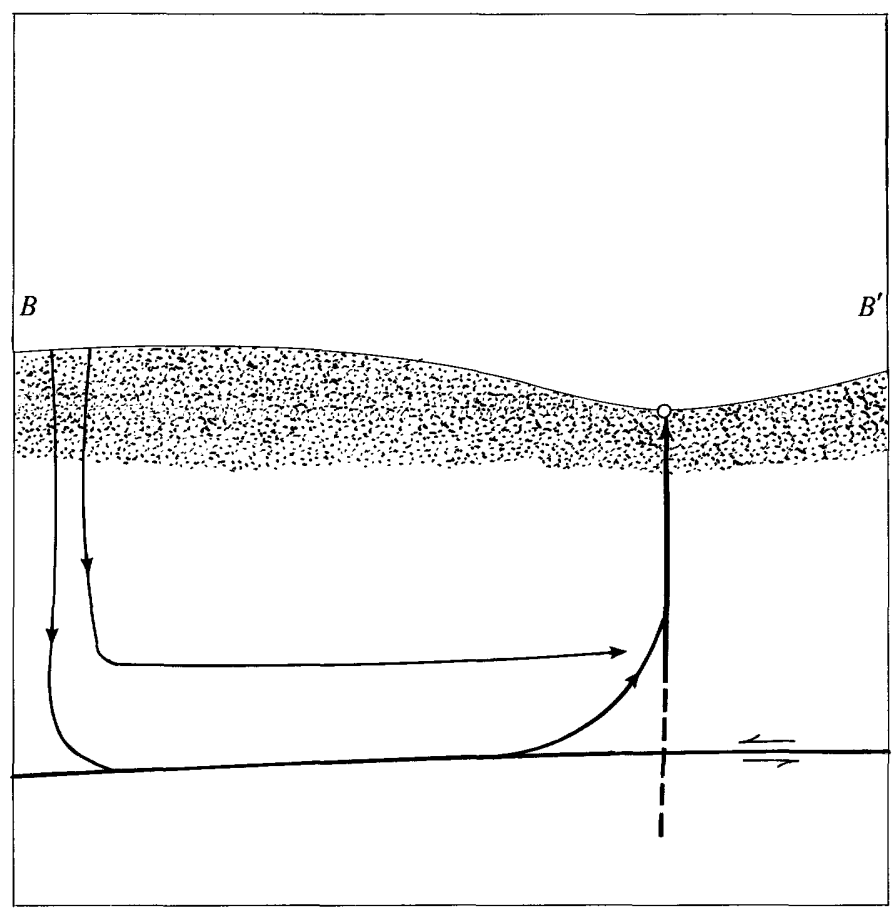

FIGURE 14.-Diagram showing possible movement of water along a vertical plane parallel to the strike of an anticlinal ridge.

wells in the diagram. Wells 302,304 , and 308 are drilled, at least in part, into the Oriskany Sandstone. Wells 304 and 308 were reportedly $46 \mathrm{~m}$ deep and are either dry or produced only wet clayey sand near the 


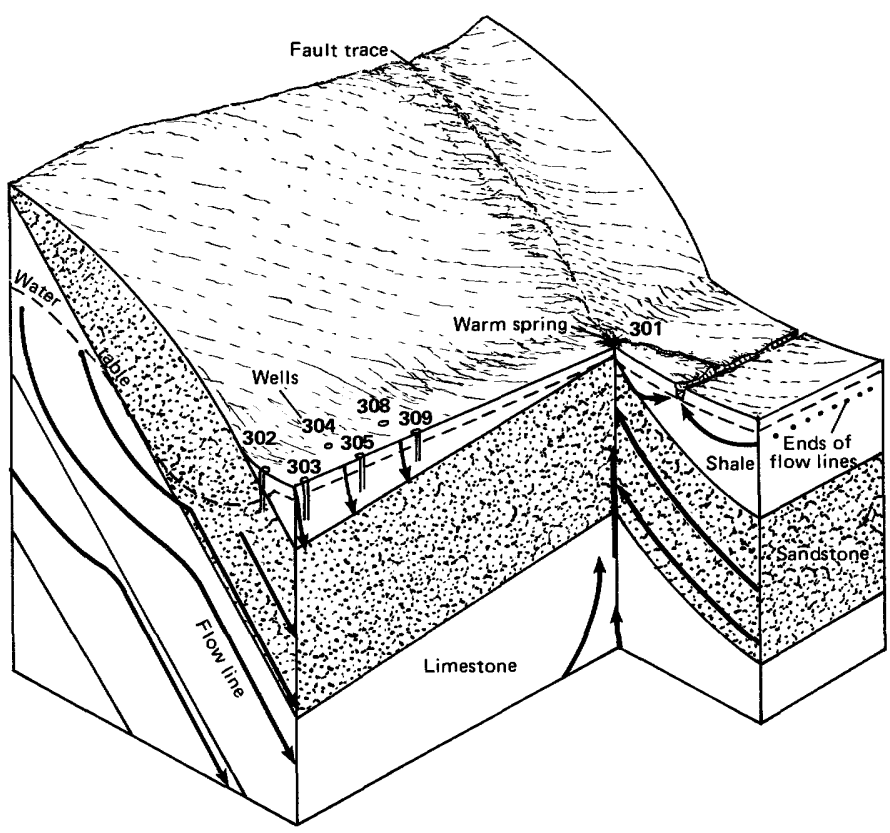

Figure 15.-Block diagram showing possible circulation of water to the warm springs at Berkeley Springs, W.Va. Water quality data suggests that most of the water discharged at the spring has circulated only through the sandstone.

bottom. Well 302 is the only one in the sandstone that has not been destroyed. It is $121 \mathrm{~m}$ deep; in the upper $116 \mathrm{~m}$ it penetrates the Marcellus Shale, and in the bottom 4.5-6.0 $\mathrm{m}$ it penetrates the Oriskany Sandstone. During drilling some water entered the well at less than $18 \mathrm{~m}$, but it was cased off with $19 \mathrm{~m}$ of casing. When this well was first visited on August 19, 1975 , the water level was $31 \mathrm{~m}$ below land surface. At this time the well had filled with loose sand to a depth of less than $107 \mathrm{~m}$. In order to get a water sample from the Oriskany Sandstone, the well was cleaned out on October 16, 1975. At this time water was observed squirting into the well above $49 \mathrm{~m}$, and the water level recovered to about $49 \mathrm{~m}$. On May 19, when the well was sampled again, the water level was $50.1 \mathrm{~m}$, and some of the water, still squirting into the well, was entering between 29 and $32 \mathrm{~m}$. The higher head in the shale favors movement of water from the shale into the sandstone. Prior to removal of the sand, the water level was higher because fine sand had partially plugged the well bore, impeding flow down the hole and into the Oriskany Sandstone. The water on January 14, 1976, was at about $189 \mathrm{~m}$ altitude-the same as the warm spring at Berkeley Springs. This level was about $37 \mathrm{~m}$ lower than the altitude of the main stream channels draining to the northeast on either side of the Warm Springs Ridge. Wells 304 and 308 reportedly were drilled to depths of about $46 \mathrm{~m}$ and were either dry or had wet clayey sand near the bottom. If these reports are accurate, then the water table at these wells may be lower than the altitude of the warm spring. Despite a difference in water-level, this area could still be the recharge area for the warm spring, because the column of warm water rising at the spring could be driven by a column of lesser head of cooler, more dense water in the recharge area. For example, a $600.0-\mathrm{m}$ column of water at $22^{\circ} \mathrm{C}$ at the springs could be balanced by a $599.0-\mathrm{m}$ column of water at $13^{\circ} \mathrm{C}$ in the recharge area.

If ground water from the area of wells 302,304 , and 308 does not discharge to the warm spring, it must discharge to Sir Johns Run, or to the Potomac River, north or west of the warm spring. Subsurface flow toward the north or west is possible, but permeability across the strike of the bedding probably is not great enough to permit a high flow rate. Also, if such flow were happening, the water that now discharges at the spring probably would be diverted underground to Sir Johns Run or the Potomac River.

Assuming recharge of about $880,000 \mathrm{~L} /$ day per $\mathrm{km}^{2}$ into the sandstone-limestone aquifer, the recharge area necessary to maintain the flow of the warm spring is about $10.6 \mathrm{~km}^{2}$. If the actual area of recharge is assumed to be all the ridge to a distance of $6.1 \mathrm{~km}$ south of the spring and parts of the valleys on either side of the ridge (which is $1.3 \mathrm{~km}$ wide), the recharge area is about $9.8 \mathrm{~km}^{2}$, or approximately the inferred area of recharge. However, if a large amount of recharge were derived from the streams on either side of Warm Spring Ridge, the actual recharge area would be indeterminate.

The chemical content of the water discharging from Berkeley Springs suggests that nearly all the water is derived from the Oriskany Sandstone. However, the water shifts from a calcium magnesium bicarbonate type at high flow toward a sodium chloride type at low flow. This shift indicates that a part of the water is derived from either a deeper formation or the overlying shale.

Rough computations can be made to estimate the likelihood that all the spring water is derived from recharge entering the outcrop of the Oriskany Sandstone. First, recharge is assumed to be 880,000 $\mathrm{L} / \mathrm{day} / \mathrm{km}^{2}$ or $320 \mathrm{~mm} / \mathrm{yr}$ in the $9.8-\mathrm{km}^{2}$ outcrop area. This high rate is believed reasonable because of the permeable nature of the Oriskany Sandstone in this area. Grimsley (1916 p. 224) described an outcrop at Rock Gap Run eight miles south of Berkeley Springs as forming "an apparently solid wall sloping at a high angle to the east valley, but when struck with a hammer it is found to be soft and crumbly, it being almost impossible to secure a solid hand specimen of the rock." Grimsley (1916, p. 224) described another outcrop, about four miles north of Berkeley Springs, as a conglomerate "composed of small or large white pebbles imbedded in a loose white sand matrix which crumbles 


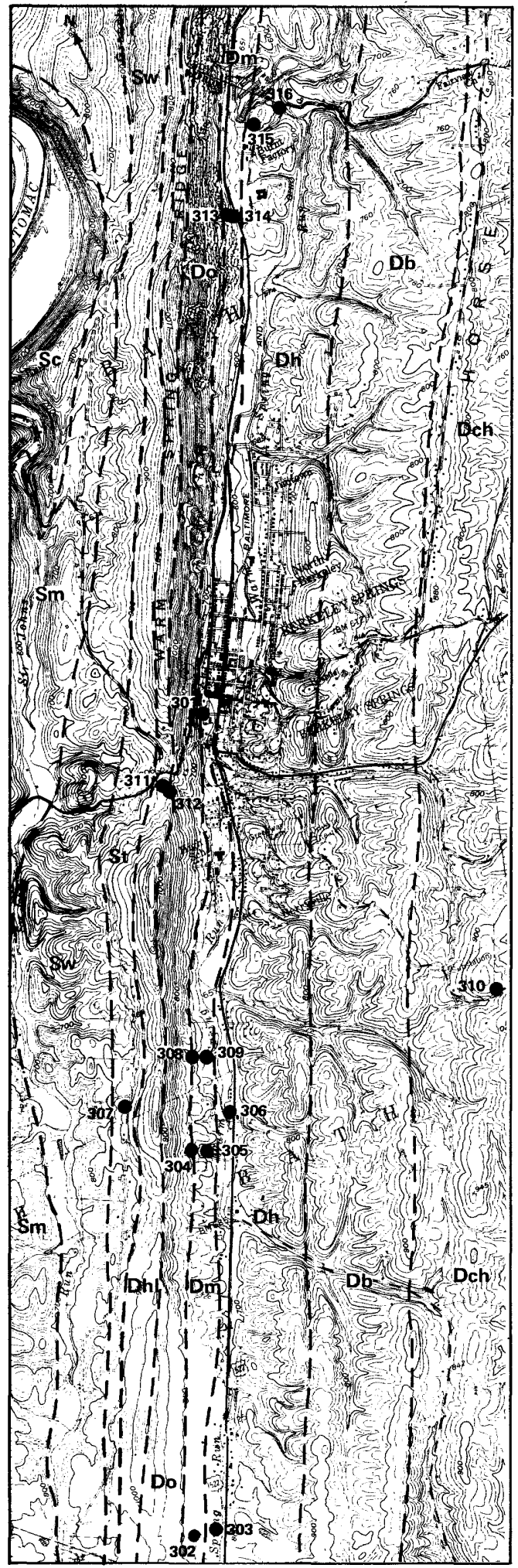

\section{EXPLANATION}

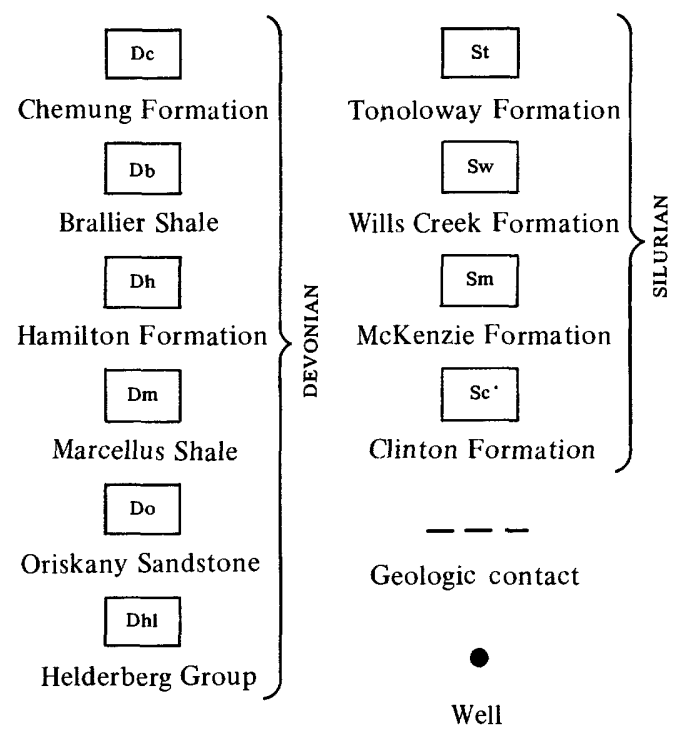

(Geology after Grimsiey, 1916) $1 / 2$

FIGURE 16.-Map showing geology and spring and well locations near Berkeley Springs, W. Va.

to a gravel." Thus, it is reasonable to infer a large amount of recharge from precipitation on poorly cemented rocks such as these. If all the recharge for the spring enters a $300-\mathrm{m}$ wide outcrop of the Oriskany Sandstone from $18 \mathrm{~km}$ south of the spring and $4.8 \mathrm{~km}$ north of the spring, only two-thirds of the measured 
flow of the spring can be accounted for. However, additional recharge is known to come from the overlying Marcellus Shale, and perhaps some also comes from the underlying limestones. If the spring derives water from as far as $18 \mathrm{~km}$ to the south, additional recharge could also be derived from Rock Gap Run, which flows across the sandstone outcrop (where Grimsley described the rocks). Thus, at least two-thirds of the discharge of the spring is probably derived from direct recharge on the Oriskany.

R. T. Hurr (Lohman, 1972, p. 53) reports an average hydraulic conductivity value of $9 \mathrm{~m} /$ day for medium to fine alluvial sand. This value converts to a transmissivity value (T) of about $900 \mathrm{~m}^{2} /$ day for the Oriskany Sandstone, which ranges in thickness from 90 to $120 \mathrm{~m}$ and averages about $100 \mathrm{~m}$. Using a slope (I) of $2.33 \times 10^{-3}$ for the water table from the spring to Rock Gap Run, the length of aquifer (L) required to supply the actual discharge of the spring $(Q), 110$ liters per second, was computed by the relationship $Q=$ TIL and found to be $4,500 \mathrm{~m}$. Thus, the water discharging at Berkeley Springs could be derived from recharge entering 4,500 $\mathrm{m}$ of the Oriskany Sandstone outcrop if sufficient recharge were available. However, all or most of the recharge comes from precipitation, and if our earlier assumption of $880,000 \mathrm{~L} / \mathrm{day} / \mathrm{km}^{2}$ for recharge is reasonable, then recharge must be entering the rocks over as much as $18-23 \mathrm{~km}$ of the outcrop.

It should be mentioned here that other nearby areas apparently duplicate the geology at Berkeley Springs (Hobba and others, 1972). The hydrology is similar too in that the water levels in the sandstone hills (formed by the Oriskany Sandstone), are lower than water levels in the adjacent shale valleys, much the same as the area south of Berkeley Springs. However, in these other areas, large cold springs are usually located some distance downgradient and along the strike of the rocks. At Berkeley Springs the only known large spring downgradient and along strike is the Warm Spring. Apparently the only difference between this warm spring and the cold ones is the depth of water circulation. The hydrologic situation near Baker, W. Va. (96 km southwest of Berkeley Springs) suggests that deep circulation may have occurred there in the past. The geologic conditions at this site are essentially the same as those at Berkeley Springs, except that the rocks dip to the west and a large cold spring discharges in the valley from a cavern in the Tonoloway Formation, which lies stratigraphically about $107 \mathrm{~m}$ below the Oriskany Sandstone. A dye-tracer study showed that the spring is hydraulically connected to a large sinkhole in the same limestone in an upland valley about $3 \mathrm{~km}$ northeast of the spring. The large cavity at the spring is below the intersection of a thrust fault and a vertical fracture. At some time in the geologic past, when this large conduit was smaller and buried beneath hundreds of meters of rock, it is conceivable that it supplied water to a thermal spring. The age of the cavern is unknown, but it may be very old, since it is supplied water from such a large sinkhole which drains an area of about $2.5 \mathrm{~km}^{2}$. Regardless of whether this system ever supplied water to a warm spring or not, cavernous circulation systems do develop parallel to the anticlinal ridges along certain formations and perhaps along faults. If developed to a great enough depth, such a system may give rise to a warm spring.

The hydraulic system at Hot Springs, Va. may be similar to the one near Baker, W. Va. One well (607) at Hot Springs obtains warm water from a 0.6-m-high cavern at a depth of $230 \mathrm{~m}$. No significant amount of water was encountered in the well above that depth, and well yield exceeded $30 \mathrm{~L} / \mathrm{s}$ for a 53 hour pumping period. This high sustained yield suggests a waterfilled cavern system at depth. Thermal springs having various temperatures and yields are found at both Hot Springs and Healing Springs, Va. which are $5.6 \mathrm{~km}$ apart along the crest of the anticline in Warm Springs Valley (fig. 10). A topographic high separates the two thermal-spring areas in the Valley. A well drilled in this topographic high (near well 611) was $91 \mathrm{~m}$ deep; this well penetrated caverns and was dry. If the water table is at or below $91 \mathrm{~m}$, its altitude is near that of the thermal springs at Hot Springs but well above that of the springs at Healing Springs. On the basis of the yield of Healing Springs and Hot Springs and an assumed rate of recharge of $730,000 \mathrm{~L} / \mathrm{day} / \mathrm{km}^{2}(270$ $\mathrm{mm} / \mathrm{yr}$ ) in the area between the springs, this recharge would supply half the total water discharged at the two spring areas. The other half of the water required is available in the part of the valley north of Hot Springs and that part south of Healing Springs plus any contribution from the ridges on either side of the valley.

Warm Springs in Georgia discharges from a sandstone formation which dips $25^{\circ}-30^{\circ}$ beneath the Manchester Schist. Hewett and Crickmay (1937), inferred that the recharge for Warm Springs is derived from precipitation on Pine Mountain (fig. 3B). They concluded (1937, p. 33) that there are lower and upper permeable zones in the Hollis Quartzite, separated by a nearly impermeable middle unit. Water enters the lower permeable bed on Pine Mountain and flows downdip to where the rocks are broken by Towaliga Fault. At this point the water moves upward into the upper permeable beds and then back updip to discharge at the warm spring. Not enough new data are available to draw definite conclusions as to the pattern of circulation at this warm spring. If Warm Springs derives its water from the area of Pine Mountain south 
and southwest of the springs, and if the water flows to depth and if it is heated by a normal geothermal heat flow, then the springs may be part of a flow system similar to the type Hewett and Crickmay (1937) have described. However, a flow system similar to the one described for Berkeley Springs is also possible. That is, recharge entering the Hollis Quartzite on Pine Mountain may circulate to a depth parallel to schistosity along open fractures, joints, and faults and rise along a highly permeable zone to discharge at the springs. Figure 2 indicates that a lineament may pass through the warm springs. In either case, the water at the springs would have been derived principally from recharge on exposures of the Hollis Quartzite.

\section{TEMPERATURE OF THERMAL WATERS}

FLLCTLATIONS

The temperatures of the thermal springs investigated range from $17.7^{\circ} \mathrm{C}$ at Perry County Warm Springs in Pennsylvania to $41.7^{\circ} \mathrm{C}$ at Hot Springs, N.C. Continuous recording thermographs were installed at Warm Springs, Va., and at Minnehaha Springs, W. Va., in the fall of 1975 . The thermographs showed temperature fluctuations of about $0.3^{\circ} \mathrm{C}$ at Warm Springs over an 8-month period and less than $1^{\circ} \mathrm{C}$ at Minnehaha Springs over a 3-month period.

Recording instruments were also used by Hewett and Crickmay (1937) at Warm Springs, Ga., and by Costain (1976) at Hot Springs, Va. The temperature at a central discharge point at Warm Springs varied from $30.9^{\circ}-31.2^{\circ} \mathrm{C}$ in a year and a half. However, the temperature at opposite ends of the 150-m-long discharge belt were $26.1^{\circ} \mathrm{C}$ and $28.3^{\circ} \mathrm{C}$. Thus, there is a difference of about 5 degrees between the warmer and cooler wa- ters discharged by the springs. Our measurements of the temperature of the combined flow from all the sources varied only $0.4^{\circ} \mathrm{C}$ when sampled in December 1975 and May 1976. Costain (oral commun., 1976) found that the temperature of Boiler Spring at Hot Springs, Va., was essentially constant during a 1-month period during which a thermograph was installed. Our measurements at the times of sampling showed a temperature variation of only $0.1^{\circ} \mathrm{C}$ at Boiler Spring. However, the temperatures of other nearby warm springs fluctuated as much as $12.2^{\circ} \mathrm{C}$ during the same period.

Weekly measurements were made by observers at Berkeley Springs, W. Va., and at Hot Springs, N. C., using maximum-temperature thermometers. The temperature at the discharge point observed at Berkeley Springs varied from $22.0^{\circ} \mathrm{C}$ to $22.2^{\circ} \mathrm{C}$; that at Hot Springs varied from $36.8^{\circ}$ to $41.7^{\circ} \mathrm{C}$ (fig. 17). (To date, $41.7^{\circ} \mathrm{C}$ is the highest known temperature measured at any of the thermal springs in the eastern United States.) The major temperature fluctuations here are caused by cool river water moving into the spring house during times of high flow in the river. Figure 17 shows that when the river stage rises to a level higher than about $1.5 \mathrm{~m}$, water may move into the overflow pipe or through the alluvium and reduce the temperature of the spring.

From 1949 to 1955 flow and temperature measurements were made at Bolar Spring by the Virginia District of the U. S. Geological Survey. Figure 18 shows that there is generally an inverse relationship between discharge and temperature. This indicates that the spring water probably is a mixture of deep circulating warm water and shallow circulating cool water.

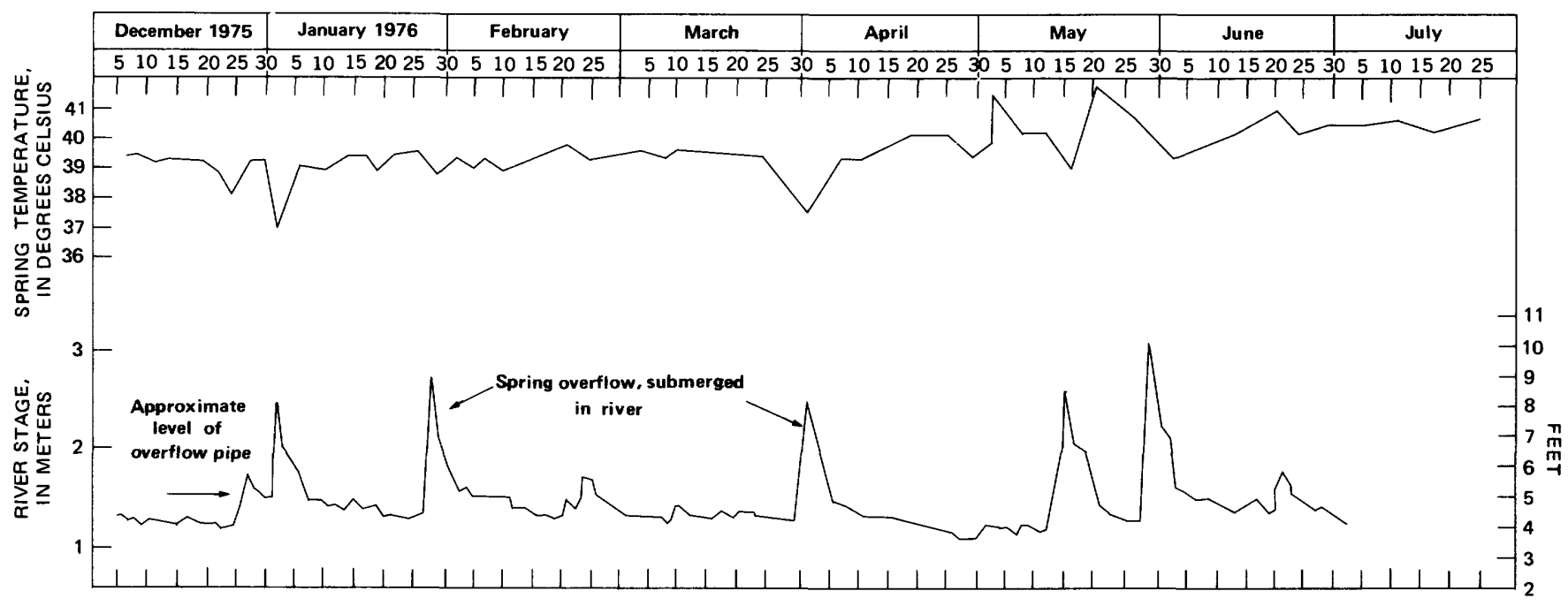

FiguRE 17.-Water temperature of hot spring and stage of the French Broad River at Hot Springs, N.C. 


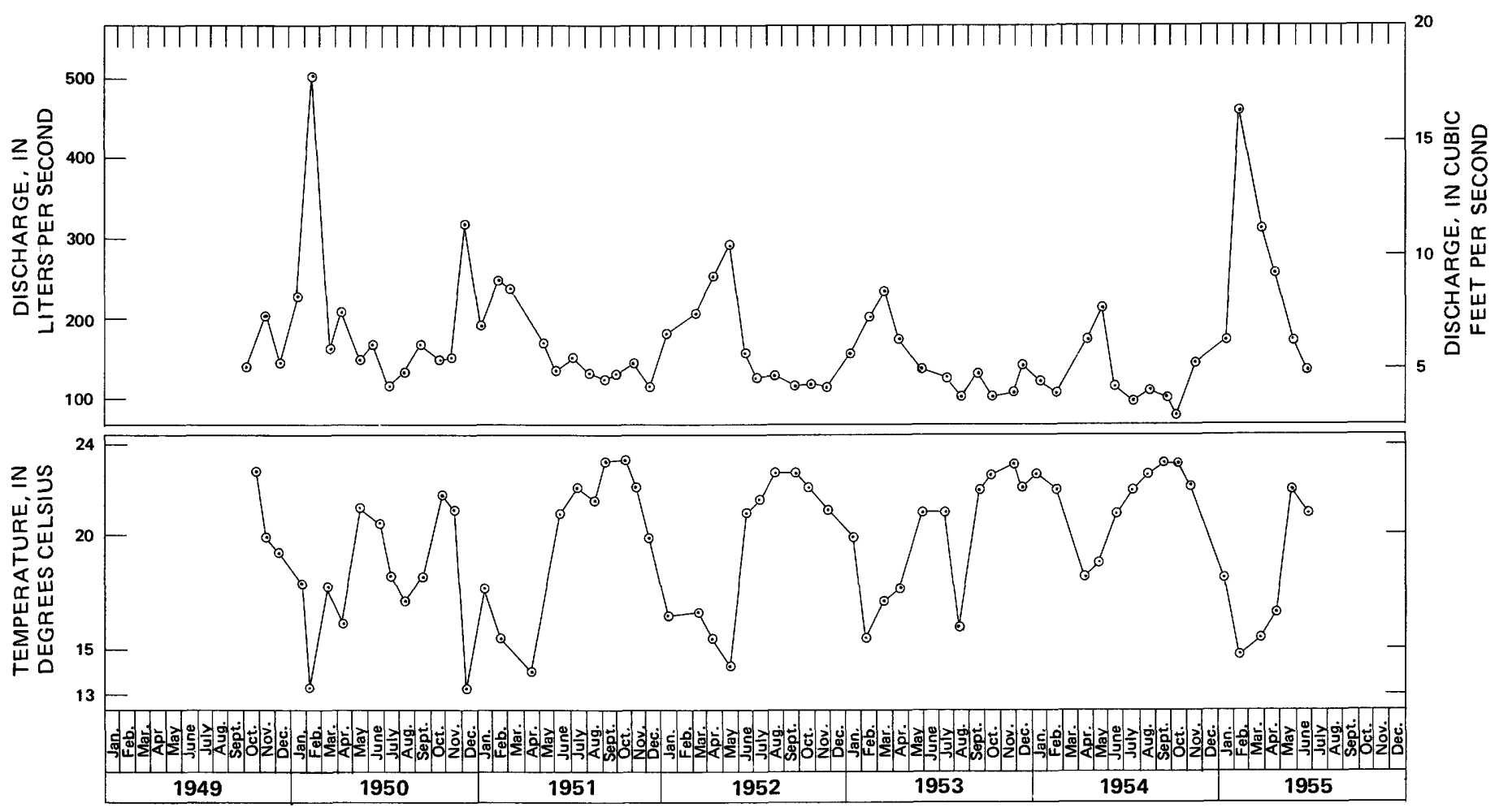

FIGURE 18.-Temperature and discharge of Bolar Spring at Bolar, Va.

Weinman (1976) measured the temperature of Perry County Warm Springs periodically; he found that it fluctuated from $17.5^{\circ}$ to $19.5^{\circ} \mathrm{C}$. He also found that even though this spring is not very warm, the temperature difference is great enough to appear on low altitude thermal imagery. Our measurements at the times of sampling varied only from $17.8^{\circ} \mathrm{C}$ in the fall to $17.7^{\circ} \mathrm{C}$ in the spring.

The temperatures at Lebanon Springs, N. Y., and Falling Spring, Va., were measured only at times of sampling. Lebanon Springs varied from $21.9^{\circ} \mathrm{C}$ in the fall to $18.7^{\circ} \mathrm{C}$ in the spring. Falling Spring varied from $25.0^{\circ} \mathrm{C}$ in the fall to $20.8^{\circ} \mathrm{C}$ in the spring. These lower temperatures during the spring suggest that the discharge is a mixture of deep-circulating warm water and cool shallow water.

\section{WELLS AND THERMAL GRADIENTS}

During this investigation three wells were inventoried that produced warm water. Two are in Virginia and one is near Warm Springs, Ga. Temperature and other geophysical logs were obtained on one of the open wells (607) at Hot Springs, Va. The temperature and fluid conductivity logs are shown in figure 19. This hole is reported by the driller to be cased to $47.2 \mathrm{~m}$ with $150-\mathrm{mm}$ casing. The only water reported is warm water from a cavern between 229.8 and $230.4 \mathrm{~m}$. However, the fluid conductivity log shows two types of water in the well: one of lower conductivity above $109.7 \mathrm{~m}$ and one of higher conductivity below $109.7 \mathrm{~m}$. Although the $\log$ shows that conductivity increases from 750 to about $1,100 \mu \mathrm{mhos} / \mathrm{cm}$ below $122 \mathrm{~m}$, much of this increase is probably caused by the increase of temperature with depth because the conductivity of point samples collected at 122 and $227 \mathrm{~m}$ were 700 and $750 \mu \mathrm{mhos} / \mathrm{cm}$, respectively, when cooled to the same temperature at land surface. The yield of the well is substantial; (it was test pumped at $30 \mathrm{~L} / \mathrm{s}$ for 53 hours). When sampled with a pump that would pump only $0.41 \mathrm{~L} / \mathrm{s}$, the temperature and specific conductance of the discharge increased from $15.0^{\circ} \mathrm{C}$ and 380 micromhos to $20.2^{\circ} \mathrm{C}$ and 670 micromhos, after $2^{1 / 2}$ hours of pumping. During the period, the water level rose $70 \mathrm{~mm}$ in the well. The rise in temperature, conductance, and water level with pumping is attributed to the warm water of higher conductivity entering the bottom of the well and moving upward. The expansion of this warm water was enough that the water level in the well increased although pressure head actually decreased.

Figure 19 shows the temperature log for well 302 near Berkeley Springs, W. Va., and that of the warm well at Hot Springs, Va. At well 302 the cool water is flowing into the well from the Marcellus Shale, down the well bore, and out into the Oriskany Sandstone, the 


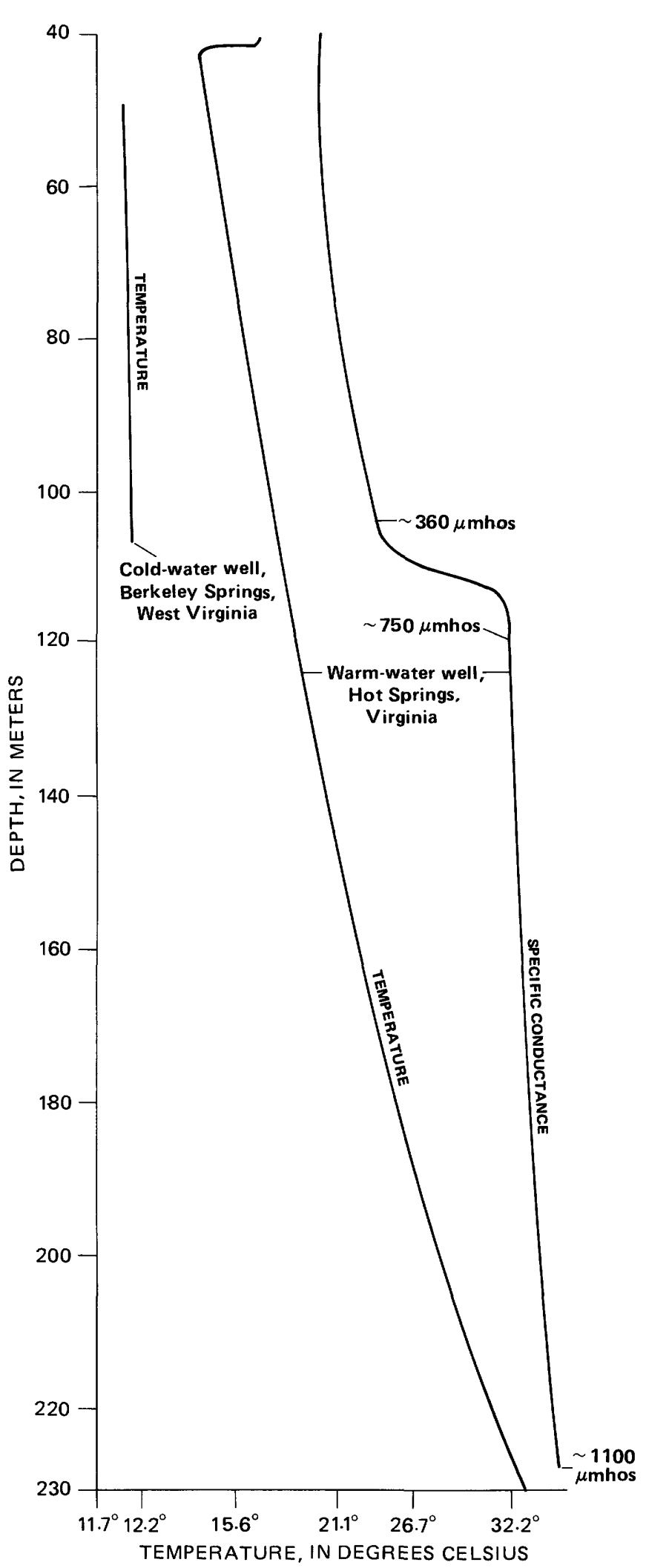

Figure 19.-Logs showing temperature for a cold-water well and temperature and fluid conductivity for a warm-water well. top of which lies at about $116 \mathrm{~m}$. This well is thought to be located in the recharge area for the warm spring of Berkeley Springs. The warm water in the well at Hot Springs is flowing in at the bottom of the well, up the well bore, and out into the overlying formations. This well is thought to be located in the same discharge area as the thermal springs at Hot Springs, Va.

Increases in temperature and conductance with time of pumping were common to all the wells that produced warm water. The temperature and conductance of well 702 near Falling Spring, Va. steadily increased to $27.2^{\circ} \mathrm{C}$ and 1,050 micromhos after more than one hour's pumping. With continuous pumping the temperature of water from this well is reported by the tenant to reach $35^{\circ} \mathrm{C}$. After one and one-half hours of pumping, the temperature and conductance of well 907 near Warm Springs, Ga., had increased to $33.8^{\circ} \mathrm{C}$ and 100 micromhos. This is $2.6^{\circ} \mathrm{C}$ higher than the highest temperatures observed at the Warm Springs (Hewett and Crickmay 1937, p. 5). Possibly this well is tapping the conduit that supplies warm water to the spring, or perhaps the water from the well is mixed with a smaller amount of cool water than the water from the spring.

Thermal gradients were computed using bottom hole temperatures or maximum temperatures of water pumped from wells (table 1). It is apparent from table 1 that some of the shallow hot wells have thermal gradients about 100 times that computed for well 302 near Berkeley Springs. The small gradient at well 302 can be explained by the downward flow of cold water in the well. The large gradient in the warm wells can be explained by the upward movement of warm water from depth. The thermal gradients for test well 703 in Virginia and gas well Pocahontas \#21 in West Virginia are considered about normal for the eastern United States.

Figure 20 is the temperature log for gas well Pocahontas \#21. It shows a nearly linear increase in temperature with depth. This well is $3,111 \mathrm{~m}$ deep and

TABLE 1.-Thermal gradients at wells producing warm or cold water

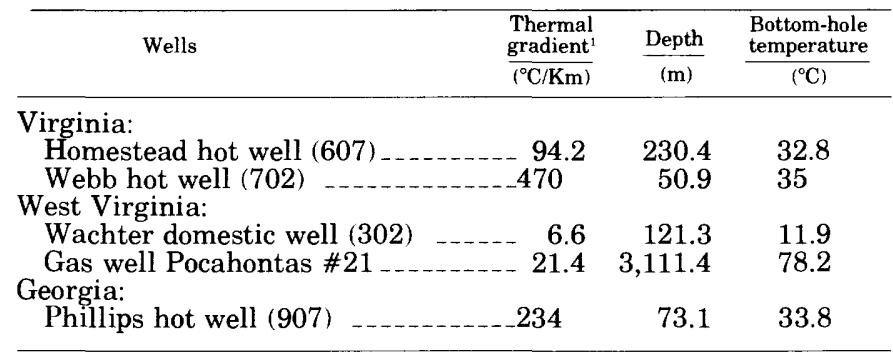

'Thermal gradient computed from bottom hole temperature and local shallow ground-water temperature. For water wells, highest measured or reported water temperature was astemperature. For water wells, highest
sumed to be bottom hole temperature. 


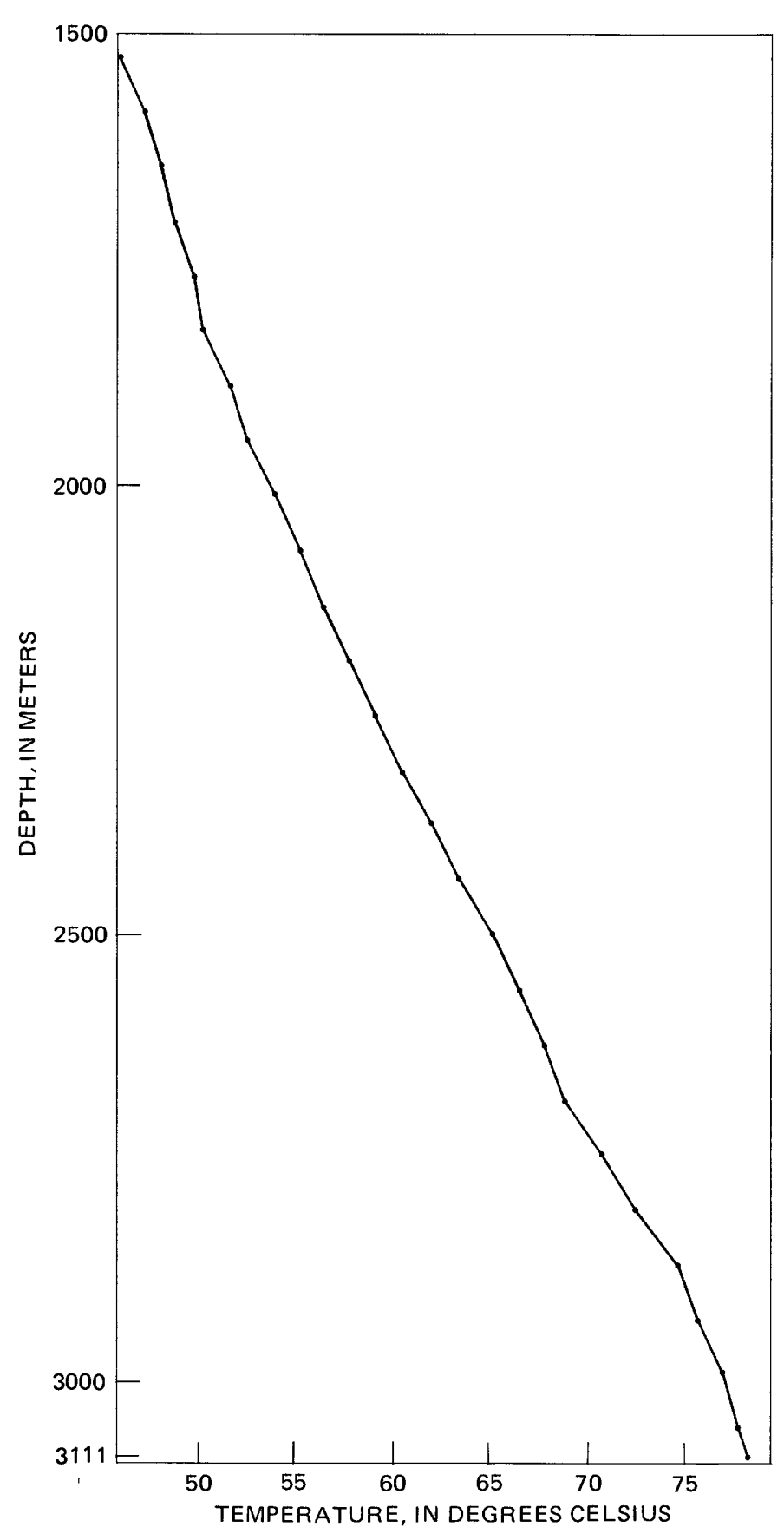

Figure 20.-Temperature log for air-filled "dry" gas well (Pocahontas 21) near Minnehaha Springs, W. Va.

is $3 \mathrm{~km}$ southwest of Minnehaha Springs, W. Va. It penetrates the Cambrian and Ordovician rocks that underlie the warm spring areas of West Virginia, Virginia, and Pennsylvania. The thermal gradient here is $21.4^{\circ} \mathrm{C} / \mathrm{km}$. On the basis of this thermal gradient, the depth of circulation at Minnehaha Springs is estimated to be more than $450 \mathrm{~m}$. Table 2 shows minimum depths of circulation at these warm spring areas inferred on the basis of known geothermal gra-
TABLE 2.-Estimated depths of circulation based on thermal gradients and conduction losses

\begin{tabular}{|c|c|c|c|}
\hline Springs & $\begin{array}{l}\text { Thermal } \\
\text { gradient } \\
\left({ }^{\circ} \mathrm{C} / \mathrm{Km}\right)\end{array}$ & 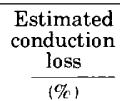 & $\begin{array}{c}\text { Minimum } \\
\text { depth of } \\
\text { circulation } \\
\frac{(\mathrm{m})}{}\end{array}$ \\
\hline Lebanon Springs, NY & ${ }^{1} 26.6$ & 5 & 500 \\
\hline Perry Co. Warm Springs, Pa & 126.6 & 3 & 250 \\
\hline Berkeley Springs, WV & ${ }^{1} 23.0$ & 3 & 500 \\
\hline Minnehaha Springs, WV & ${ }^{2} 21.4$ & 2 & 450 \\
\hline Bolar Spring, Va & 1320.0 & 2 & 600 \\
\hline Warm Springs, Va $\ldots . .$. & ${ }^{13} 20.0$ & 6 & 1,300 \\
\hline Hot Springs, Va & 1320.0 & 8 & ${ }^{+} 1,600$ \\
\hline Falling Spring, $\mathrm{Va}$ & ${ }^{13} 20.0$ & 2 & 51,450 \\
\hline Hot Springs, NC & ${ }^{6} 24.8$ & 3 & 1,300 \\
\hline Warm Springs, Ga & 21.2 & 5 & 750 \\
\hline
\end{tabular}

'Am. Assoc. Petroleum Geologists and U. S. Geol. Survey, 1976. ${ }^{2}$ Measured in nearby gas well Pocahontas \#21.

'Lowell, 1975 , p. 356.

"For the hottest spring.

${ }^{5}$ Costain (1976), p. 31 ) reports a thermal gradient of about $9.3^{\circ} \mathrm{C} / \mathrm{km}$ in a $305 \mathrm{~m}$ test hole near Falling Spring, Va. If this is the representative gradient for the Virignia area, minimum depths of circulation may be more than twice that shown for the Virginia springs.

Stose and Stose, 1947, p. 644.

iHewett and Crickmay, 1937, p. 35

dients, assumed temperature equilibrium at depth, and estimated conduction losses. Conduction losses were estimated from measured spring flows, temperature, and the following assumed values (Lowell, 1975, p. 353-356): thermal conductivity of the rock $(2.5 \mathrm{~W}$ $\left.\mathrm{m}^{-1}{ }^{\circ} \mathrm{C}^{-1}\right)$, specific heat of water $\left(4.2 \times 10^{3} \mathrm{j} \mathrm{kg}^{-1}{ }^{\circ} \mathrm{C}^{-1}\right)$, thickness of the resistance (heat-transfer) layer equals depth of circulation, and fracture lengths equal $1 \mathrm{~km}$ for small springs and $10 \mathrm{~km}$ for large springs.

\section{HEAT DISCHARGE}

An impressive amount of heat is carried to the earth's surface and released by the thermal springs. Computations based on flow and temperature data show that the heat released at larger but cooler springs such as Falling Spring and Bolar Spring, Va, is much greater than that released at the smaller but warmer springs (table 3 ). Since the discharge at these cooler springs is a mixture of warm and cold water, the components of hot water must be either larger or hotter than that emerging at the smaller warmer springs. Thus, it seems that areas of the springs with the greatest heat output (as power equivalent) would be the best areas to investigate for geothermal potential.

\section{GEOCHEMISTRY}

By D. W. Fisher, F. J. Pearson, Jr., and J. C. Chemerys

\section{GENERAL PRINCIPLES}

Several combinations of processes can lead to the appearance of thermal water ${ }^{1}$ at the earth's surface. The chemical and isotopic measurements discussed here

${ }^{1}$ Thermal water is considered herein to be water having a temperature above the mean annual temperature near the earth's surface. 
TABLE 3.-Flow, temperature, and power output of thermal springs

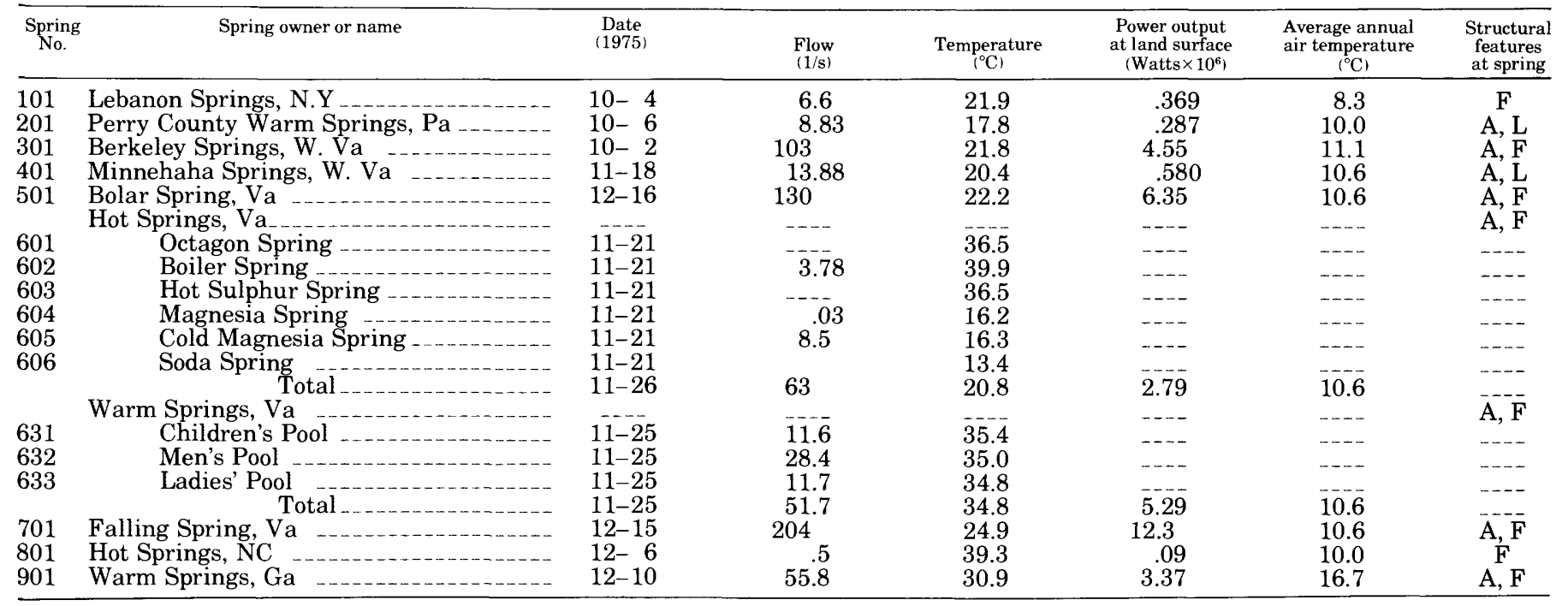

A Crest or flank of anticline

L Intersection of lineaments or faults.

were intended to identify which of several possible combinations of processes gave rise to the observed surface temperatures of the thermal springs and wells sampled.

The processes can be envisioned as follows: Ground water is in some way heated-for example, by deep circulation in a region of so-called "normal geothermal heat flow." The water presumably attains temperature equilibrium with the aquifer rock at depth. This water may then flow to the surface rapidly enough so that it neither loses appreciable heat by conduction to nearsurface cooler rocks nor mixes with cooler, shallowcirculating ground water. The surface temperature of such a water is that of the region in which it was originally heated. On the other hand, the heated water may ascend slowly, losing heat by conduction, in which case its surface temperature will be below its maximum temperature at depth, but it will show no evidence of having been mixed with shallow, cooler water. Finally, if the heated water mixes with cool, shallow water before issuing forth at the surface, its surface temperature will also be below its maximum temperature at depth, but it should have characteristics which show that it is a mixture.

The measurements made on the samples from the systems described here were intended to permit the estimation of the maximum temperatures attained by the heated component of each of the systems. The measurements and their use are described in detail below. Briefly, they include tritium measurements to estimate the amount of cool shallow water present in each sample, measurements of dissolved constituents which are useful as geothermometers or as qualitative indi- cators of heat-generating reactions, and consideration of the carbonate geochemistry of the samples as indicators of the aquifer rock type through which the water has passed.

\section{GEOCHEMICAL INDICATORS}

Cation and anion distributions and total mineralization are useful for delineating differences between waters from various sources. Values of dissolved-solids concentrations, a measure of total mineralization, calculated as the simple sums of analyzed cations, anions, and nonvolatile neutral constituents, are listed in table 4. Variations in cation and anion distributions are discussed under the individual warm-spring areas.

\section{DISSOLVED GASES}

Dissolved gas concentrations can also be helpful in understanding the geochemistry of waters. High dissolved oxygen is typical of a water that has had little contact with organic matter or sulfide minerals during its subsurface travel. On the other hand, the presence of methane and (or) hydrogen sulfide in a water signifies highly reducing conditions in the aquifer through which the water flows. Dissolved oxygen concentrations of the sampled Appalachian warm springs exceed $>3 \mathrm{mg} / \mathrm{L}$ except for those in the Hot SpringsWarm Springs area of Virginia, where levels range from 0.1 to $2 \mathrm{mg} / \mathrm{L}$. A hydrogen sulfide concentration of $0.75 \mathrm{mg} / \mathrm{L}$ in the Warm Springs sample (631) suggests that sulfide minerals may be consuming the dissolved oxygen of the recharge to these warm springs.

Roberts, Friedman, Donovan, and Denton (1975) have proposed the use of helium concentrations in soil 
TABLE 4.-Temperatures and selected analytical data for waters in Appalachian warm-spring areas

[Locations and hydrologic data for these wells and springs are given in Hobba, Friel, and Chisholm (1977)]

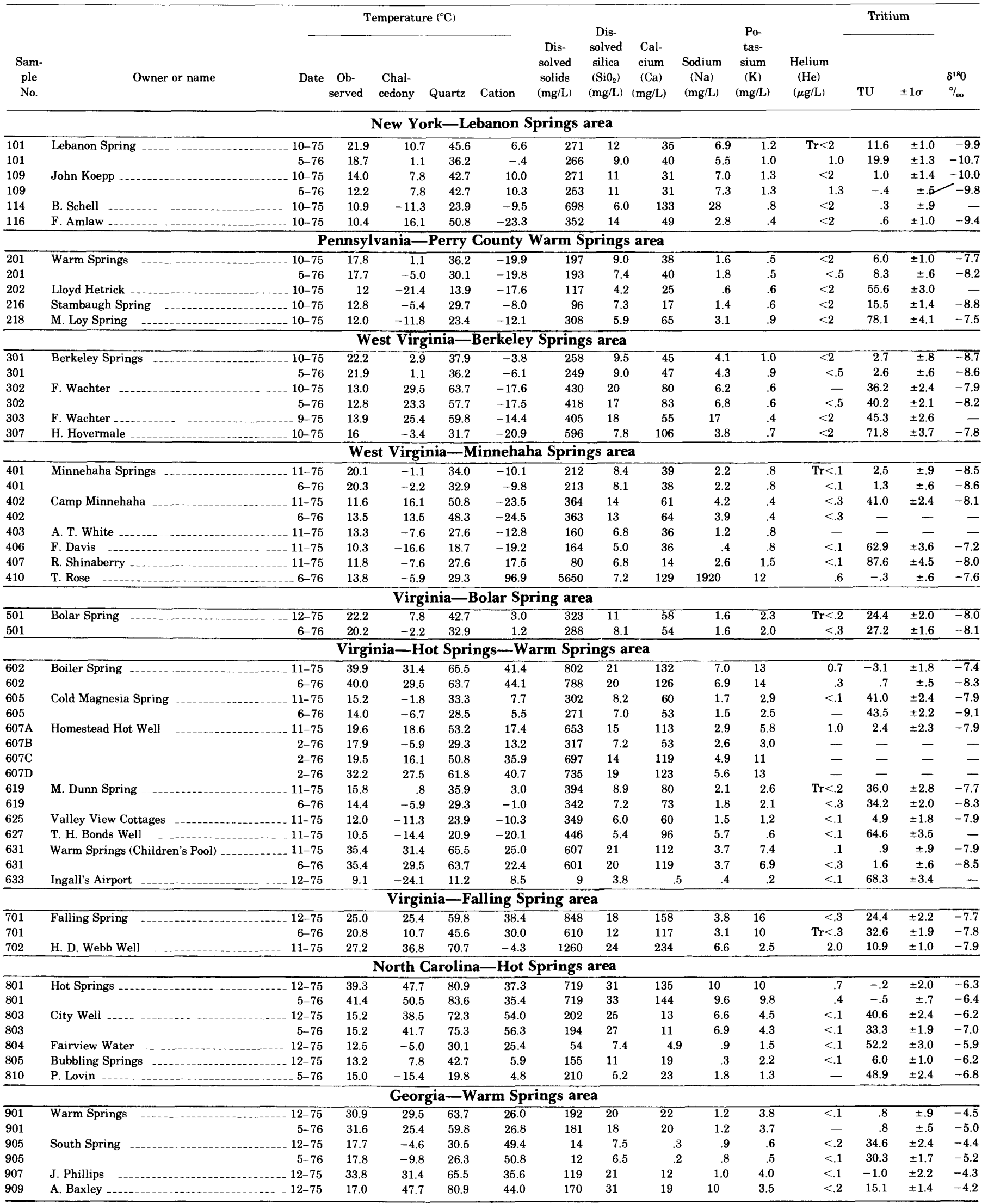


gas as a geothermal prospecting tool. They observed close correlation between helium levels and proximity to hot-water seeps at several locations in the western states; the effect was ascribed to escape of helium from the hot water into the local soil gas. Heat and helium are generated during the radioactive decay of uranium and thorium minerals. Decay of ${ }^{238} \mathrm{U}$ to stable ${ }^{206} \mathrm{~Pb}$ and ${ }^{4} \mathrm{He}$ evolves $=3.5 \times 10^{10}$ calories of heat per gram of helium created (from data in Birch, 1954). Calculations based on these data show that the heat produced by the number of decay events needed to add $l \mu \mathrm{gHe} / \mathrm{L}$ is about $35 \times 10^{3}$ calories. If all this heat were absorbed and retained by the water, its temperature would rise about $35^{\circ} \mathrm{C}$. Of course, in a ground-water system, much of this heat is dissipated by conduction in the aquifer material itself, so that the observed temperature increase will be smaller than the theoretical $35^{\circ} \mathrm{C} /$ $\mu$ gmHe. However, an elevated dissolved-He concentration is still an indication of a subsurface heat source consisting of a concentration of radioactive minerals in or near the aquifer, and independent of the depth of circulation of the water.

Dissolved helium cannot be used as a quantitative geothermal indicator largely because of the nature of helium gas. It is the least soluble and among the most mobile of all gases and may escape from solution before the water reaches the sampled spring or well, producing the soil gas effect noted by Roberts and at the same time reducing the dissolved helium level. Helium concentrations of the Appalachian water samples are listed in table 4 . Water at equilibrium with $5 \times 10^{-6}$ atmospheres of $\mathrm{He}$ (sea-level value for the normal atmosphere) will contain less than $0.01 \mu \mathrm{g} / \mathrm{L}$ of the dissolved gas. Thus, all positive findings of He noted in the table (i.e., Trace, $>0.1 \mu \mathrm{g} / \mathrm{L}$ and greater) indicate substantial supersaturation with respect to the atmosphere.

Dissolved carbon dioxide analyses provide an independent check on the field $\mathrm{pH}$ and aklalinity determinations. In this study, the gas analysis $\mathrm{CO}_{2}$ values help to provide better carbonate system data. Accurate values of carbonate ion activities are obviously essential for geochemical studies of water-carbonate mineral reactions. Ordinarily, field measurements of $\mathrm{pH}$ and bicarbonate alkalinity, together with calculations of activity coefficients and ion pairing of the major solutes, are used to determine the carbonate ion activities of a water. An alternative method, involving calculation of a $\mathrm{pH}$ from the analyzed $\mathrm{CO}_{2}$ pressures and field alkalinities, was used in determing carbonate species activities for several of these Appalachian waters. The calculations are described by Pearson, Fisher, and Plummer (in preparation). Carbonate mineral saturation data derived by both methods are listed in table 5 .
Carbonate ion activities are very sensitive to $\mathrm{pH}$. The analyzed $\mathrm{CO}_{2}$-calculated $\mathrm{pH}$ method may be advantageous for calculating carbonate ion activities of high $\mathrm{P}_{\mathrm{CO}_{2}}$ waters, which may evolve $\mathrm{CO}_{2}$, thereby increasing $\mathrm{pH}$ during $\mathrm{pH}$ determinations. We consider the errors in analyzed $\mathrm{P}_{\mathrm{CO}_{2}}$ values to be $<5$ percent for $\mathrm{P}_{\mathrm{CO}_{2}}>5 \times 10^{-3}$ atm. Calculation of $\mathrm{pH}$ from the $\mathrm{P}_{\mathrm{CO}_{2}}$ depends on the relationship

$$
\mathrm{CO}_{2}+\mathrm{H}_{2} \mathrm{O} \rightleftarrows \mathrm{H}^{+}+\mathrm{HCO}_{3}^{-}
$$

with an equilibrium constant

$$
\mathrm{K}_{\mathrm{PO}_{2}}=\frac{\mathrm{a}_{\mathrm{H}}+\mathrm{a}_{\mathrm{HCO}_{3}}-}{\mathrm{P}_{\mathrm{CO}_{2}} \mathrm{a}_{\mathrm{H}_{2} \mathrm{O}}}
$$

Noting that $\mathrm{pH}=-\log \mathrm{a}_{\mathrm{H}}{ }^{+}$, or $10^{\mathrm{pH}}=\frac{1}{\mathrm{a}_{\mathrm{H}}{ }^{+}}$,

and rearranging, we obtain

$$
10^{\mathrm{pH}}=\left(\frac{1}{\mathrm{P}_{\mathrm{CO}_{2}}}\right)\left(\frac{\mathrm{a}_{\mathrm{HCO}_{3}}^{-}}{\mathrm{a}_{\mathrm{H}_{2} \mathrm{O}} \mathrm{K}_{\mathrm{P}_{\mathrm{CO}_{2} 2}}}\right)
$$

From (A), an error in $\mathrm{P}_{\mathrm{CO}_{2}}$ of 5 percent would correspond to a change of about 5 percent in $10^{\mathrm{pH}}$, or a $\mathrm{pH}$ difference of 0.02 units. In contrast, direct $\mathrm{pH}$ measurements in ground waters are normally no more precise than \pm 0.05 units (Langmuir, 1971; Pearson and Rettman, 1976).

Recent studies of the $\mathrm{CO}_{2}$ system in the oceans have made increasing use of measured $\mathrm{P}_{\mathrm{CO}_{2}}$ rather than $\mathrm{pH}$ as one of the parameters employed for determinations of carbonate ion activity (for example, $\mathrm{Li}$ and others, 1969). A discussion of the relative merits of various approaches to these determinations was presented by Park (1969).

\section{TRACE ELEMENTS}

Dissolved trace elements are sometimes useful qualitative indicators of geothermal waters. Truesdell (1976) has reviewed recent geothermal studies in which trace element concentrations help to define geothermal reservoirs. Arsenic was found in 8 of the 10 warm springs sampled, indicating a possible correlation between this element and the thermal history of the waters. However, the levels of arsenic determined $(0.5-0.2 \mu \mathrm{g} / \mathrm{L}$, the lower detection limit) do not permit an assessment of the role of arsenic as a thermal indicator in these waters.

\section{ISOTOPES}

Ratios of stable-oxygen isotopes and stable-carbon isotopes, and the concentration of the radioactive isotope of hydrogen, tritium, were measured in many of the samples. Oxygen isotopes are qualitative indicators of the geography of the area of recharge of a 
TABLE 5.-Saturation indexes and carbon-isotope ratios for waters in Appalachian warm-spring areas

\begin{tabular}{|c|c|c|c|c|c|c|c|c|c|c|c|c|c|c|}
\hline \multirow{3}{*}{$\begin{array}{l}\text { Sam- } \\
\text { ple } \\
\text { No. }\end{array}$} & \multirow{3}{*}{ Owner or name } & \multirow{3}{*}{ Date } & \multicolumn{6}{|c|}{ Carbonate chemistry based on measured $\mathrm{pH}$} & \multicolumn{6}{|c|}{ Carbonate chemistry based on analyzed $\mathrm{CO}_{2}$} \\
\hline & & & \multirow{2}{*}{$\begin{array}{c}\text { Meas- } \\
\text { ured } \\
\text { pH }\end{array}$} & \multirow{2}{*}{$\begin{array}{c}\text { Calcu- } \\
\text { lated } \\
\mathrm{P}_{\mathrm{CO2}} \\
\text { (atm.) }\end{array}$} & \multirow{2}{*}{$\begin{array}{c}\text { Total } \\
\text { car- } \\
\text { bonate } \\
(\mathrm{mM} / \mathrm{L})\end{array}$} & \multicolumn{2}{|c|}{ Saturation index } & \multirow{2}{*}{$\begin{array}{c}\text { Meas- } \\
\text { ured } \\
\delta^{13} \mathrm{C}_{\mathrm{PDB}} \\
\%\end{array}$} & \multirow{2}{*}{$\begin{array}{c}\text { Calcu- } \\
\text { lated } \\
\text { pH }\end{array}$} & \multirow{2}{*}{$\begin{array}{l}\text { Ana- } \\
\text { lyzed } \\
\mathrm{P}_{\mathrm{CO} 2} \\
\text { (atm.) }\end{array}$} & \multirow{2}{*}{$\begin{array}{c}\text { Total } \\
\text { car- } \\
\text { bonate } \\
\text { (mM/L) }\end{array}$} & \multicolumn{2}{|c|}{ Saturation index } & \multirow{2}{*}{$\begin{array}{c}\text { Ad- } \\
\text { justed } \\
\delta^{13} \mathrm{C}_{\mathrm{PDB}} \\
\%_{\mathrm{oo}}\end{array}$} \\
\hline & & & & & & $\begin{array}{l}\text { Cal- } \\
\text { cite }\end{array}$ & $\begin{array}{l}\text { Dolo- } \\
\text { mite }\end{array}$ & & & & & $\begin{array}{l}\text { Cal- } \\
\text { cite }\end{array}$ & $\begin{array}{l}\text { Dolo- } \\
\text { mite }\end{array}$ & \\
\hline
\end{tabular}

New York-Lebanon Springs area

\begin{tabular}{|c|c|c|c|c|c|c|c|c|c|c|c|c|c|}
\hline 101 & Lebanon Spring & 7.60 & 0.0038 & 2.86 & -0.11 & -0.33 & -11.9 & 7.60 & 0.0039 & 2.86 & -0.11 & -0.32 & -11.9 \\
\hline 101 & $5-76$ & 7.72 & .0029 & 2.89 & +.03 & -.19 & -11.9 & 7.55 & .0043 & 2.95 & -.14 & -.52 & -12.1 \\
\hline 109 & John Koepp & 7.60 & .0034 & 2.74 & -.30 & -.71 & -13.1 & 7.87 & .0018 & 2.66 & -.03 & -.18 & -12.8 \\
\hline 109 & $5-76$ & 8.00 & .0013 & 2.63 & +.07 & -.05 & -11.9 & 7.86 & .0018 & 2.66 & -.06 & -.32 & -12.0 \\
\hline 114 & B. Schell & 7.20 & .0093 & 3.53 & -.20 & -1.32 & - & - & - & - & - & - & - \\
\hline 116 & F. Amlaw & 7.55 & .0055 & 4.23 & -.04 & -.33 & -11.5 & - & - & - & - & - & $=$ \\
\hline \multicolumn{14}{|c|}{ Pennsylvania-Perry County Warm Springs area } \\
\hline 201 & Warm Springs & 7.20 & .0077 & 2.53 & -.59 & -2.05 & -13.4 & 7.43 & .0045 & 2.39 & -.36 & -1.58 & 13.0 \\
\hline 201 & $5-76$ & 7.62 & .0029 & 2.29 & -.16 & -1.28 & -12.6 & 7.48 & .0040 & 2.34 & -.30 & -1.56 & 12.8 \\
\hline 202 & Lloyd Hetrick _........... 10-75 & 6.85 & .0088 & 1.62 & -1.45 & -4.01 & - & - & - & - & - & - & - \\
\hline 216 & Stambaugh Spring & 6.50 & .0160 & 1.73 & -2.04 & -4.84 & -12.9 & - & - & - & - & - & - \\
\hline 218 & M. Loy Spring & 7.20 & .0092 & 3.34 & -.37 & -.95 & -12.3 & - & - & - & - & - & - \\
\hline \multicolumn{14}{|c|}{ West Virginia-Berkeley Springs area } \\
\hline$\overline{301}$ & Berkeley Springs & 6.99 & .0163 & 3.35 & -.59 & -1.85 & -15.2 & 6.98 & .0166 & 3.36 & -.60 & -1.86 & -15.2 \\
\hline 301 & $5-76$ & 7.46 & .0054 & 2.89 & -.12 & -.98 & -13.9 & 6.94 & .0180 & 3.36 & -.64 & -2.02 & -14.9 \\
\hline 302 & F. Wachter - & 6.80 & .033 & 5.78 & -.34 & -1.80 & -15.5 & - & - & - & - & - & - \\
\hline 302 & $5-76$ & 7.07 & .0174 & 4.88 & -.27 & -1.33 & -15.5 & - & - & - & - & - & - \\
\hline 303 & F. Wachter & 7.30 & .0095 & 4.14 & -.24 & -.75 & - & - & - & - & - & - & - \\
\hline 307 & H. Hovermale & 6.97 & .037 & 8.35 & -.02 & -.50 & -15.2 & - & - & - & - & - & - \\
\hline \multicolumn{14}{|c|}{ West Virginia-Minnehaha Springs area } \\
\hline$\overline{401}$ & Minnehaha Springs _.... $11-75$ & 7.88 & .0014 & 1.94 & +.04 & -.51 & -11.4 & 7.82 & .0016 & 1.95 & -.02 & -.62 & -11.4 \\
\hline 401 & $6-76$ & 7.90 & .0013 & 1.90 & +.04 & -.54 & -11.4 & 7.72 & .0020 & 1.93 & -.13 & -.90 & -11.5 \\
\hline 402 & Camp Minnehaha & 7.30 & .0095 & 4.24 & -.21 & -.89 & -14.4 & - & - & - & - & - & - \\
\hline 402 & $6-76$ & 7.30 & .0096 & 4.23 & -.16 & -.86 & - & - & - & - & - & - & 一 \\
\hline 403 & A. T. White - & 7.20 & .0045 & 1.59 & -.87 & -3.30 & - & - & - & 一 & - & - & - \\
\hline 406 & F. Davis & 7.63 & .0022 & 1.96 & -.36 & -2.06 & -13.1 & - & - & - & - & - & - \\
\hline 407 & R. Shinaberry -- & 5.50 & .055 & 3.11 & -3.59 & -8.10 & -22.9 & - & - & - & - & - & - \\
\hline 410 & T. Rose & 7.68 & .0039 & 4.61 & +.28 & +.17 & +2.1 & 7.95 & .0021 & 4.50 & +.58 & +.71 & +2.3 \\
\hline \multicolumn{14}{|c|}{ Virginia-Bolar Spring area } \\
\hline 501 & Bolar Spring _ & 7.48 & .0063 & 3.58 & +.06 & -.25 & -9.2 & 7.30 & .0097 & 3.71 & -.12 & -.61 & -9.5 \\
\hline 501 & & 7.42 & .0065 & 3.28 & -.09 & -.68 & -10.1 & 7.40 & 0067 & 3.29 & -.10 & -.72 & -10.1 \\
\hline \multicolumn{14}{|c|}{ Virginia-Hot Springs-Warm Springs area } \\
\hline 602 & Boiler Spring -- & 6.65 & $\overline{0.117}$ & $10.2 \overline{3}$ & +0.07 & -0.05 & -5.6 & 6.61 & 0.127 & 10.48 & +0.03 & -0.12 & -5.7 \\
\hline 02 & & 6.55 & .147 & 10.92 & -.05 & -.32 & -5.8 & 6.69 & .107 & 9.96 & +.09 & -.04 & -5.4 \\
\hline 605 & Cold Magnesia Spring __._._. 11-75 & 7.20 & .0095 & 3.28 & -.37 & -1.35 & -8.8 & - & - & - & - & - & - \\
\hline 605 & $6-76$ & 7.15 & .0099 & 3.13 & -.51 & -1.70 & -9.8 & - & - & - & - & - & - \\
\hline $607 \mathrm{~A}$ & Homestead Hot Well & 7.15 & .022 & 6.85 & +.14 & -.01 & -7.5 & 6.68 & .066 & 8.58 & -.32 & -.94 & -8.9 \\
\hline 619 & M. Dunn Spring & 7.32 & .0080 & 3.56 & -.11 & -.77 & -10.4 & - & - & - & - & - & - \\
\hline 619 & 6-76 & 7.42 & .0058 & 3.19 & -.09 & -.90 & -7.4 & - & - & - & - & - & - \\
\hline 625 & Valley View Cottages & $7: 30$ & .0103 & 4.57 & -.17 & -.77 & -7.7 & - & - & - & - & - & - \\
\hline & T. H. Bond's well & 7.48 & .0080 & 5.32 & +.26 & -.50 & - & 7.26 & .0134 & 5.61 & +.03 & -.95 & - \\
\hline 631 & Warm Springs & 7.32 & .0101 & 3.46 & +.24 & -.21 & -8.2 & 7.08 & .0175 & 3.66 & .00 & -.26 & -8.5 \\
\hline & (Children's Pool) & 7.20 & .0132 & 3.50 & +.14 & -.06 & -8.8 & 7.10 & .0165 & 3.59 & .04 & -.26 & -9.0 \\
\hline 633 & Ingall's Airport & 4.50 & .055 & 3.07 & -7.0 & -14.3 & - & - & - & - & - & - & - \\
\hline \multicolumn{14}{|c|}{ Virginia-Falling Spring area } \\
\hline 701 & Falling Spring & 7.32 & .0139 & 5.63 & +.41 & +.38 & -6.8 & 7.13 & $.02 \overline{17}$ & 5.91 & +.22 & .00 & -7.1 \\
\hline 701 & $6-76$ & 7.32 & .0109 & 4.49 & +.17 & -.16 & -8.4 & 7.10 & .0177 & 4.77 & -.05 & -.60 & -8.8 \\
\hline & H. D. Webb well & 7.80 & .0275 & 7.80 & +.49 & +.66 & -8.0 & 6.60 & .098 & 10.09 & -.05 & -.43 & -9.5 \\
\hline \multicolumn{14}{|c|}{ North Carolina-Hot Springs area } \\
\hline$\overline{801}$ & Hot Springs & 7.50 & .0045 & 2.15 & +.31 & +.30 & $-\overline{9} .5$ & $7 . \overline{28}$ & $.007 \overline{4}$ & 2.23 & +.10 & -.12 & -9.7 \\
\hline 801 & $5-76$ & 7.50 & .0043 & 2.03 & +.35 & +.27 & -9.2 & - & - & 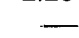 & - & - & - \\
\hline 803 & City well & 6.75 & .0179 & 2.68 & -1.61 & -3.16 & -19.3 & - & - & - & - & - & - \\
\hline 803 & & 6.88 & .0127 & 2.36 & -1.57 & -3.06 & -19.2 & - & 一 & 一 & 一 & - & 一 \\
\hline 804 & Fairview Water _ & 7.10 & .0020 & 5.75 & -2.26 & -4.53 & -12.0 & - & - & - & - & - & - \\
\hline 805 & Bubbling Springs & 7.75 & .0016 & 1.84 & -.49 & -1.07 & -13.4 & - & - & - & - & - & 一 \\
\hline 81 & P. Lovin & 8.10 & .0009 & 2.25 & +.04 & +.05 & - & - & - & - & - & - & - \\
\hline \multicolumn{14}{|c|}{ Georgia-Warm Springs area } \\
\hline$\overline{901}$ & $\ldots \ldots-12-75$ & 7.40 & .0053 & 2.15 & -.48 & -.97 & -13.7 & 7.20 & .0083 & 2.24 & -.67 & -1.28 & -14.0 \\
\hline 901 & $5-76$ & 6.95 & .0146 & 2.35 & -.97 & -1.89 & -14.5 & 7.19 & $(.0083)$ & 2.17 & -.73 & -1.40 & -14.0 \\
\hline 905 & South Spring & 4.00 & .288 & 1.22 & -7.4 & -14.8 & -30.1 & - & - & - & - & - & - \\
\hline 905 & & 4.90 & .024 & 1.05 & -6.9 & -13.8 & -24.3 & - & - & - & - & - & - \\
\hline 907 & $12-75$ & 6.42 & .028 & 1.82 & -1.93 & -3.69 & -16.4 & - & - & - & - & - & - \\
\hline 909 & A. Baxley $\ldots \ldots$ & 7.02 & .0081 & 1.89 & -1.22 & -2.98 & -20.0 & - & - & - & 一 & 一 & - \\
\hline
\end{tabular}


ground water and of whether a ground water has reacted with rock at temperatures greater than about $150^{\circ} \mathrm{C}$. Carbon isotopes indicate the types and extent of chemical reactions between ground water and carbonate minerals. Tritium has a relatively short half life (12.3 years), and nearly all tritium now in the hydrosphere was injected within the last 20 years. The tritium content reflects whether a ground water was recharged more than about 20 years ago or more recently, and frequently it is possible to use intermediate tritium values to estimate the proportions of young and old water in a mixed sample.

Stable isotope ratios are reported in $\delta$ notation. $\delta$ represents the deviation in permil (parts per thousand) of the isotope ratio in a sample from that of a standard. The ${ }^{18} \mathrm{O} /{ }^{16} \mathrm{O}$ ratio of the oxygen standard (SMOW) is similar to that of ocean water; the ${ }^{13} \mathrm{C} /{ }^{12} \mathrm{C}$ ratio of the carbon standard (PDB) is similar to that of marine limestone. Tritium concentrations are reported in tritium units (TU). One TU equals 3.2 picocuries per liter $(\mathrm{pCi} / \mathrm{L})$.

Waters on the land surface are generally depleted in ${ }^{18} \mathrm{O}$ relative to $\mathrm{SMOW}$ - that is, their $\delta^{18} \mathrm{O}$ values are negative. This depletion occurs because the vapor pressure of water molecules containing the heavier isotopes is slightly less than that of common water, $\mathrm{H}_{2}{ }^{16} \mathrm{O}$. During evaporation and condensation in the hydrologic cycle, molecules containing heavier isotopes are concentrated in the liquid phase. As water evaporates from the ocean, the vapor is depleted in ${ }^{18} \mathrm{O}$ and the amount of depletion becomes greater as the temperature of evaporation decreases. Further isotopic fractionation takes place as water is condensed and reevaporated during atmospheric transport. The amount of fractionation is inversely proportional to temperature, and also varies with altitude, latitude, and distance from the ocean.

Figure $21 A$ shows the variation of $\delta^{18} \mathrm{O}$ values of samples from this study with mean annual temperature. The lines on the figure have a slope of 0.5 permil/ ${ }^{\circ} \mathrm{C}$, within the range of 0.4 to 0.7 permil $/{ }^{\circ} \mathrm{C}$ found in more extensive studies elsewhere (Dansgaard, 1964). The two lines on the figure represent the seasonal range in $\delta^{18} \mathrm{O}$ values to be expected. Samples collected in the spring are characterized by more negative $\delta^{18} \mathrm{O}$ values which reflect the lower temperature winter precipitation; the less negative $\delta^{18} \mathrm{O}$ values of the autumn samples reflect higher temperature summer precipitation.

Oxygen isotope ratios of ground water can be changed by chemical and isotope exchange reactions between the water and the aquifer rock. Because the $\delta^{18} \mathrm{O}$ value of rock-forming minerals is strongly positive, reactions between water and rock will make the ${ }^{18} \mathrm{O}$ values of the water more positive. Such reactions occur only very slowly at temperatures below 150$200^{\circ} \mathrm{C}$. Thus, anomalously positive $\delta^{18} \mathrm{O}$ values may indicate that a ground water has been exposed to high temperatures (White and others, 1973).

As figure $21 A$ shows, the $\delta^{18} \mathrm{O}$ values of the thermal

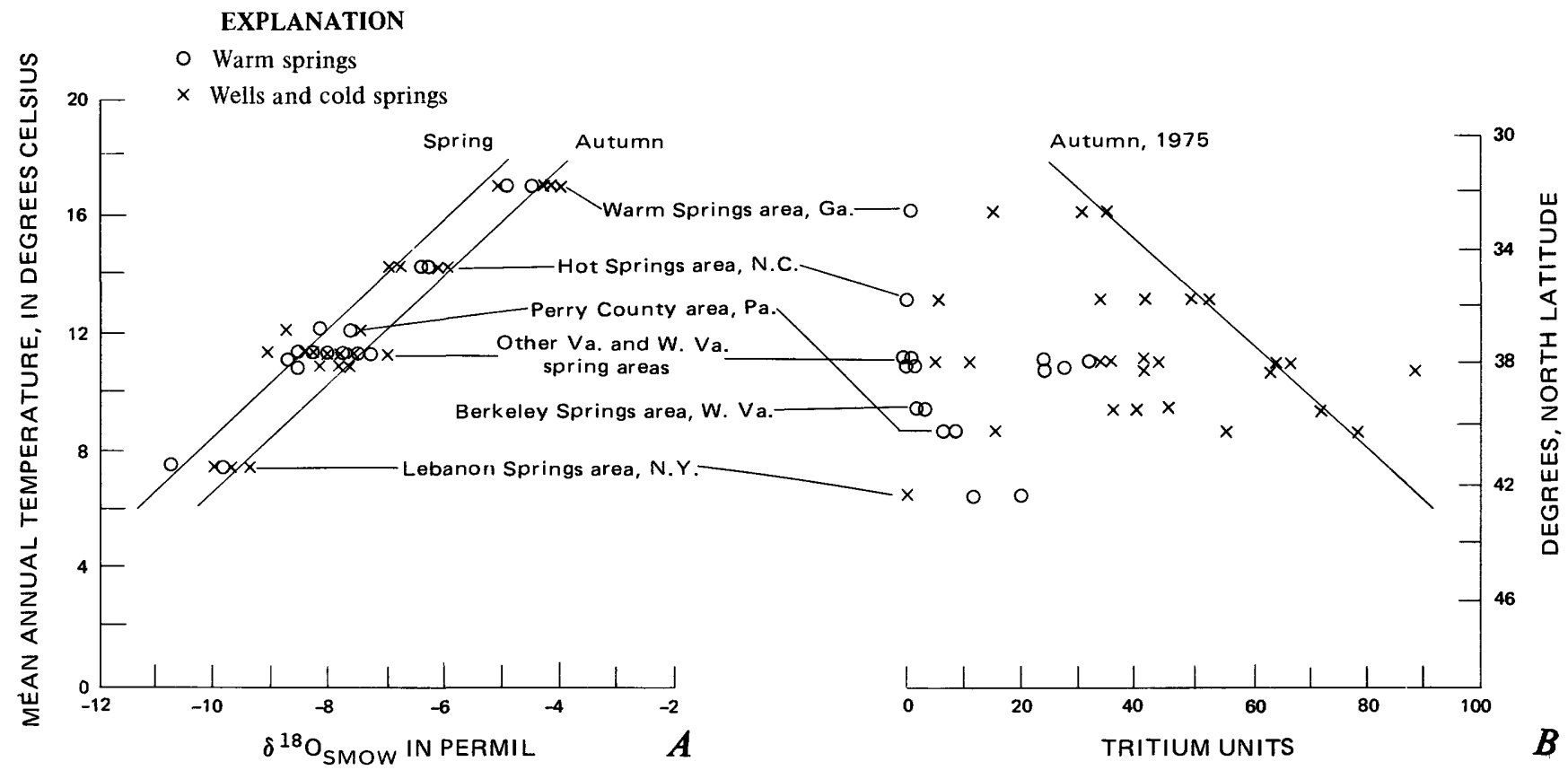

FigURE 21.-Isotopes in Appalachian warm springs area waters. $A$, Mean annual temperature and variation of $\delta^{18} \mathrm{O}$ values of samples. $B$, Latitude and variation of tritium concentration of samples. 
spring samples are within the ranges of values of the cold wells and springs in the same areas, allowing for the seasonal variations. This is evidence that the areas of recharge to the thermal spring systems are within kilometers or at most tens of kilometers from their discharge points. Further, it provides no evidence that would suggest that the thermal spring waters have been as hot as $150-200^{\circ} \mathrm{C}$.

Figure $21 B$ shows the variation of the tritium concentration of samples from this study with latitude. The line on the figure is drawn through the highest tritium values of samples collected in the autumn of 1975. The increase in tritium with latitude, by a factor of roughly 3 from $32^{\circ}-42^{\circ} \mathrm{N}$, and the tritium values themselves are what one would expect to find in ground waters which are a mixture of waters recharged since the period of major tritium injection began in the early 1960's (Stewart and Farnsworth, 1968; Stewart and Wyerman, 1970). The line may therefore be taken to represent the approximate tritium content of shallow, recently recharged ground waters at these latitudes.

Samples from the thermal springs at Warm Springs, Ga., Hot Springs, N.C., and Hot Springs and Warm Springs, Va., contain no tritium. Water from these springs is thus at least 20 years old. Tritium in the thermal springs at Bolar and Falling Spring, Va., was about 25 TU in 1975 . From the line in figure $21 B$, the maximum tritium content of shallow ground water at the latitude of these springs can be estimated to be 64 TU. If the tritium content of the thermal component of these springs is zero, the proportion of thermal ( $\mathrm{T}$ ) to shallow, $\operatorname{cool}(\mathrm{C}=1-\mathrm{T})$ water is:

$$
\begin{aligned}
& 25=\mathrm{T}(0)+64(1-\mathrm{T}) \\
& \mathrm{T}=(64-25) / 64 \approx 60 \% .
\end{aligned}
$$

The remaining thermal springs contained from 2 to 12 TU in 1975, a level corresponding to a thermal-water fraction of from 97 to 81 percent.

\section{CARBONATE CHEMISTRY AND ISOTOPES}

The carbonate chemistry of ground waters-whether the waters are in equilibrium with carbonate aquifer minerals - and the stable carbon isotope ratios of dissolved carbonate, give qualitative indications of water residence times and flow paths. Enough information is available on the warm and cold-spring samples for this study to permit a detailed interpretation of the carbonate chemistry of most of the spring systems.

Table 5 shows both the analyzed $\mathrm{P}_{\mathrm{CO}_{2}}$ and $\mathrm{P}_{\mathrm{CO}_{2}}$ values calculated from the $\mathrm{pH}$ and other chemical analyses. In some samples, such as the 1975 samples 101, 301, 401, there is good agreement between the calculated and analyzed $\mathrm{P}_{\mathrm{CO}_{2}}$ values. In others, such as 1975 samples 631 and 702 and 1976 samples 301, 701, and 602, the calculated $\mathrm{P}_{\mathrm{CO}_{2}}$ values are lower than the analyzed values.

Saturation indices (SI) for the minerals calcite and dolomite were also calculated and are given in table 2 . Both $\mathrm{P}_{\mathrm{CO}_{2}}$ and $\mathrm{SI}$ values were calculated using WATEQF (Plummer, and others, 1976). SI values calculated from measured $\mathrm{pH}$ and alkalinity values range from great undersaturation $\left(\mathrm{SI}_{\text {calcite }}<-3\right)$ in hightritium, high- $\mathrm{P}_{\mathrm{CO}_{2}}$ recharge samples to apparent oversaturation ( $\mathrm{SI}_{\text {calcite }}>+0.2$ ) in such warm-water samples as $631,701,702$, and 801 . In these apparently oversaturated samples, however, $\mathrm{P}_{\mathrm{CO}_{2}}$ calculated from $\mathrm{pH}$ and alkalinity is lower than that analyzed.

No matter how carefully a field $\mathrm{pH}$ is measured, there is always a possibility that some $\mathrm{CO}_{2}$ outgassing will occur during collection and the measurement procedure, causing an erroneously high $\mathrm{pH}$ to be read. To test this possibility, the saturation index calculations were repeated assuming that the measured $\mathrm{P}_{\mathrm{CO}_{2}}$ values were correct (Pearson, and others, in prep.). The results of these calculations are also shown in table 5.

Consider the samples of 631 as an example. On the basis of measured $\mathrm{pH}$, both samples are oversaturated with calcite and have lower calculated than analyzed $\mathrm{P}_{\mathrm{CO}_{2}}$. When recalculated from the analyzed $\mathrm{P}_{\mathrm{CO}_{2}}$ 's, however, both samples are just saturated with calcite and have lower calculated than analyzed $\mathrm{pH}$ 's. The unchanging measured temperature and the identical (within measurement precision) $\mathrm{P}_{\mathrm{CO}_{2}}$ and tritium values suggest that the chemistry of water from 631 should also be constant. The recalculated $\mathrm{SI}_{\text {calcite }}$ and $\mathrm{pH}$ values better reflect a constant chemistry than do the measured $\mathrm{pH}$ values and the SI values calculated from them. Thus the SI's based on analyzed $\mathrm{P}_{\mathrm{CO}_{2}}$ probably best represent the true state of the water chemistry.

As water recharging a ground-water system passes through the soil zone, it dissolves $\mathrm{CO}_{2}$ from the soil atmosphere. Soil $\mathrm{CO}_{2}$ is a product of plant respiration and decay, and it has $\delta^{13} \mathrm{C}$ values near $-25 \%$. If this water then passes into a marine limestone or sandstone with carbonate cement of $\delta^{13} \mathrm{C} \approx 0 \%$, the limestone or cement will dissolve in the soil $\mathrm{CO}_{2}$ charged water and produce bicarbonate with $\delta^{13} \mathrm{C}$ values as positive as -10 to $-12 \%$. In waters in rock where marine carbonate is plentiful, further reactions between rock and water may make the $\delta^{13} \mathrm{C}$ value even more positive. Thus the $\delta^{13} \mathrm{C}$ content of a ground water is a measure of the extent of reaction between the water and carbonate rock.

The measured $\delta^{13} \mathrm{C}$ values are given in table 2 , and in Hobba, Chemerys, Fisher, and Pearson (1977) where 
the method of collection and analysis is also described. If $\mathrm{CO}_{2}$ gas has been lost from a sample before or during the collection of the $\delta^{13} \mathrm{C}$ sample, the analyzed values will not be a true measure of the $\delta^{13} \mathrm{C}$ value of the source water before outgassing because of the isotopicfractionation factor of several permil between $\mathrm{CO}_{2}$ gas and dissolved carbonate species. If the $\mathrm{P}_{\mathrm{CO}_{2}}$ of the source water is known, as from a dissolved gas analysis, the correct $\delta^{13} \mathrm{C}$ can be calculated from the value measured on an outgassed sample (Pearson and others, in prep.). The $\delta^{13} \mathrm{C}$ values of those samples on which the activities of carbonate species were calculated from analyzed $\mathrm{P}_{\mathrm{CO}_{2}}$ values were also adjusted for the effects of outgassing. The adjusted $\delta^{13} \mathrm{C}$ values are given in table 2 .

The $\mathrm{SI}_{\text {calcite }}$ values, based on analyzed $\mathrm{P}_{\mathrm{CO}_{2}}$ where appropriate, and the $\delta^{13} \mathrm{C}$ values reflect the types of rock through which the various waters have traveled. Some of the cold spring samples, including numbers 407,633 , and 905, have the chemical characteristics of soil-zone waters. They have high $\mathrm{P}_{\mathrm{CO}_{2}}$ values, $\mathrm{pH}$ values lower than 6.0 and $\delta^{13} \mathrm{C}$ values about $-25 \%$. Their tritium contents show that they were recently recharged. As such waters move deeper into a ground-water system, they encounter and dissolve limestone and dolomite. This process lowers the $\mathrm{P}_{\mathrm{CO}_{2}}$, raises the $\mathrm{pH}$, and makes the $\delta^{13} \mathrm{C}$ values become more positive. Water long in contact with carbonate rock reaches saturation with calcite; however, water in contact with carbonate rock for only a short time, or in rock containing little carbonate, may be undersaturated.

The samples reflect this pattern. Thermal waters issuing from sandstone or quartzite in Perry County, Pa., Berkeley Springs, W. Va., and Warm Springs, Ga., are all undersaturated with calcite, though their low tritium contents suggest a sufficiently long residence time for saturation with calcite to have been reached if they had been exposed to carbonate rock. Samples that are associated with carbonate rock (such as 109, 602, 631 , and 801 ) and that contain little or no tritium are saturated with calcite. Those which have significant tritium contents and which represent either relatively recent waters or mixtures of waters of short or long residence times may or may not be saturated with calcite.

\section{CHEMICAL GEOTHERMOMETERS}

The measured temperature of a thermal spring or a hot-water well provides a direct indication of a subsurface heat source. However, thermal reservoir and discharge-water temperatures may not be equal; heat loss by conduction can lower the temperature of the thermal water considerably below that of the heat source. A number of geothermometers have been de- vised for estimating reservoir temperatures directly from the chemistry of thermal water samples (Truesdell, 1976). Successful application of geothermometers depends on the attainment of equilibrium in a temperature dependent water-rock reaction in the thermal reservoir, and no subsequent change in thermal water composition. The assumptions inherent in the use of geothermometers are discussed in Fournier, White, and Truesdell (1974).

Mixing of hot water with shallow, cold water often occurs in thermal spring systems. The effects of the admixture of cold water must be taken into account before estimates of reservoir temperatures can be made. In general, the temperature of the mixed water will be determined by the enthalpies of the hot and cold components (Fournier and Truesdell, 1974). At temperatures below boiling, the enthalpy of water (in calories per gram) is numerically equal to its temperature $\left(T_{\text {observed }}\right)$ of the mixed-water spring will be equal to the mean of the fractions of cold $\left(F_{\text {cold }}\right)$ and hot $\left(F_{\text {hot }}\right)$ water times the respective temperatures, or:

$$
\mathrm{T}_{\text {cold }} \cdot \mathrm{F}_{\text {cold }} \cdot+\mathrm{T}_{\text {hot }} \cdot \mathrm{F}_{\text {hot }}=\mathrm{T}_{\text {observed }}
$$

where

$$
\mathrm{F}_{\text {colll }}+\mathrm{F}_{\mathrm{hot}}=1
$$

The mixed water will also contain an intermediate concentration $(C)$ of the geochemical indicator, so that:

$$
\mathrm{C}_{\text {cold }} \cdot \mathrm{F}_{\text {cold }}+\mathrm{C}_{\mathrm{hot}} \cdot \mathrm{F}_{\text {hot }}=\mathrm{C}_{\text {analyzed }}
$$

The indicator concentration and the temperature of the cold water can be estimated for favorable cases. The geothermometer relationship between temperature and indicator concentration of the hot water

$$
\mathrm{T}_{\text {liot }}=\phi\left(\mathrm{C}_{\text {hot }}\right)
$$

then provides a unique solution of the equations for the mixing fractions and the temperature of the thermal reservoir in systems for which conductive heat loss is negligible. Alternatively, if the concentration of any conservative constituent of the hot water is known, and if this concentration differs significantly from that of the cold water component, then the mixing fractions can be determined and a hot water temperature may be calculated directly from the first three equations, and a reservoir temperature may be estimated from available geothermometers. An example of this alternative scheme for calculating mixing ratios is the use of the assumption that tritium in the hot component should 
be negligible. Then the second term in equation 3 is zero, and the cold fraction is readily calculated.

The oldest and among the most generally useful of the chemical geothermometers make use of the silica content of the sample. Reactions between water and common alumino-silicate minerals are frequently of the form:

$$
\begin{aligned}
\text { cation-Al-silicate } & +\mathrm{H}_{2} \mathrm{O} \\
& \rightarrow \mathrm{SiO}_{2(\text { (lissolvel })}+\text { cation }+ \text { Al-Silicate(s) }
\end{aligned}
$$

where the reactant cation-Al-silicate may be a sodium, potassium, or calcium feldspar or clay mineral and the product $\mathrm{Al}$-silicate is another clay mineral. The result of such reactions is to increase the dissolved silica content of the water until a silica mineral such as quartz (at relatively high temperatures) or chalcedony (at lower temperatures) precipitates. The degree to which chemical equilibrium between dissolved silica and the precipitating mineral is approached depends on the temperature and the time available for the reaction to proceed. The silica geothermometer assumes attainment of equilibrium between dissolved silica and a particular silica mineral at the reservoir temperature, with no precipitation of dissolved silica after the water has left the heated reservoir. Determination of the silica content of the water sample will then indicate the thermal reservoir temperature, provided the geothermometer has been properly calibrated for the appropriate form of silica involved in the reaction. Figure 22 is a plot of dissolved silica concentrations versus observed temperatures for the Appalachian spring and well samples. The curves represent concentrations of dissolved silica in equilibrium with quartz and with chalcedony at the indicated temperatures. They are derived from silica solubility data determined by a

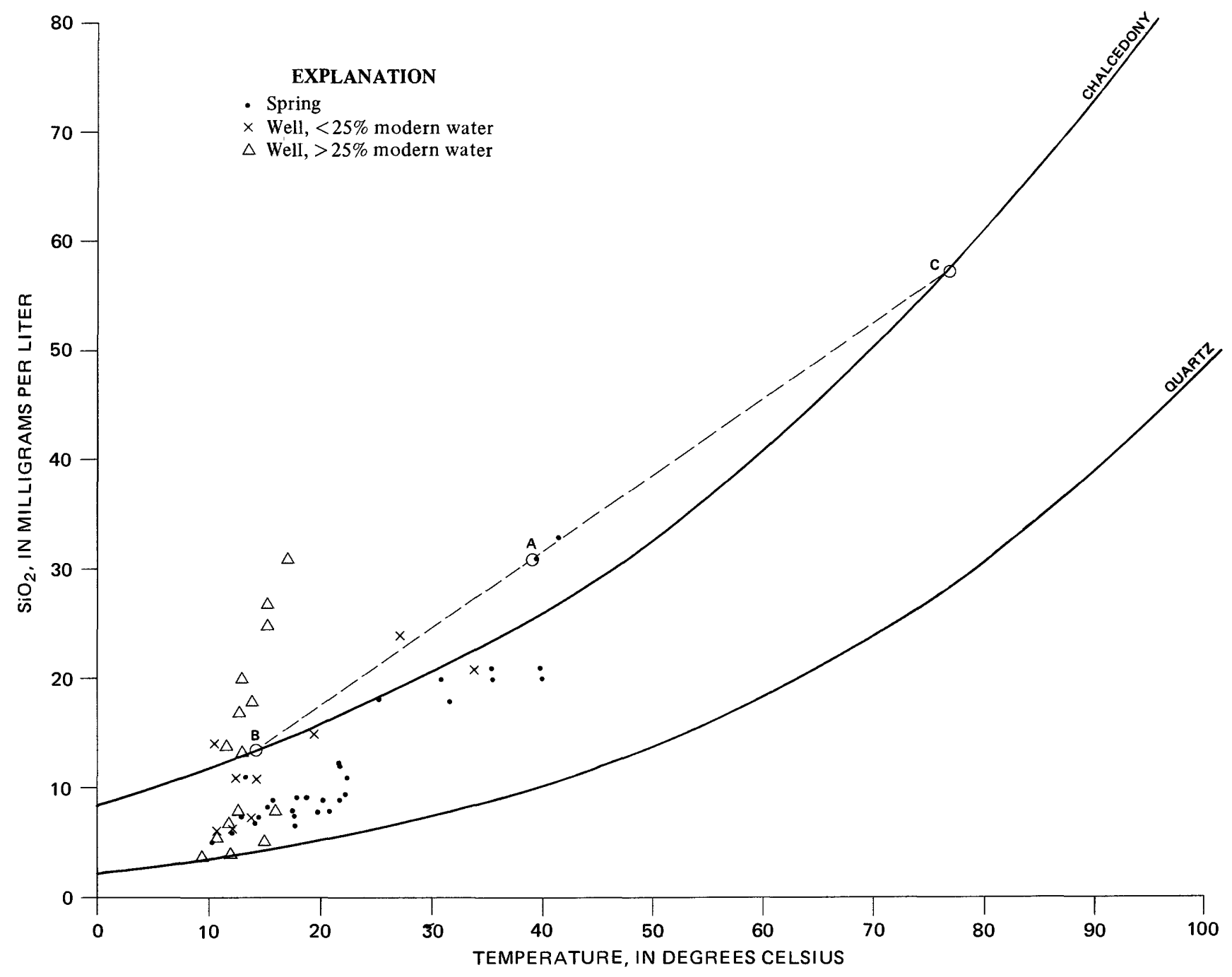

Figure 22.-Dissolved silica content and temperatures of Appalachian spring and well samples. 
number of workers and reported by Fournier (1973).

From the plotted points of figure 22, all the Appalachian spring samples are seen to be supersaturated with quartz; 2 of them (the North Carolina warm spring samples) are supersaturated with chalcedony. Well water data illustrated in figure 22 were divided into 2 age groups according to sample tritium content relative to the expected tritium level of fresh recharge in the particular geographical area (from fig. 21B.). Dissolved silica concentrations of 8 of the high-tritium well waters are above chalcedony saturation, indicating rapid low-temperature dissolution, by fresh recharge, of silica from shallow earth materials. Presumably little or no re-precipitation occurs because of slow equilibration rates for the more stable silica phases. On the other hand, the dissolved silicatemperature relationship for the older well waters is similar to that for the springs; a general increase in dissolved silica with increasing sample temperature is evident from the figure. Indicated quartz and chalcedony temperatures of the samples are included in table 4 .

Another geothermometer that has been applied with fair success in thermal systems is the Na-K-Ca or cation thermometer (Fournier and Truesdell, 1973). Unlike the silica geothermometers, which are based on laboratory measurements of silica solubilities, the cation geothermometer is empirical and the particular mineral-water reactions that make it work are not known.

The formulation of this geothermometer for waters of less than $100^{\circ} \mathrm{C}$ and with a molar ratio $\vee \mathrm{Ca} / \mathrm{Na}$ greater than 1 is:

$$
\begin{aligned}
& \mathrm{t}\left({ }^{\circ} \mathrm{C}\right)= \\
& \frac{1647}{\log (\mathrm{Na} / \mathrm{K})+(4 / 3) \log (\sqrt{\mathrm{Ca}} / \mathrm{Na})+2.24}-273.15
\end{aligned}
$$

where $\mathrm{Na}, \mathrm{K}$, and $\mathrm{Ca}$ are the concentrations of sodium, potassium, and calcium, respectively, in moles per liter.

Cation temperatures are also listed in table 4 . Temperatures calculated on samples with low $\mathrm{Ca}, \mathrm{Na}$, and $\mathrm{K}$ concentrations have large errors associated with them because of the imprecision of analysis at low concentrations. Temperatures calculated for some samples with higher $\mathrm{Ca}, \mathrm{Na}$, and $\mathrm{K}$ concentrations are negative, showing that the waters have not reached the minimum temperature necessary for the reactions that give rise to the geothermometer effect to become active. Because the cation geothermometer is empirical, this minimum temperature cannot be given unequivocally. Several of the warmest samples, including those from Warm Springs, Ga. (no. 901), Hot Springs, N.C. (no. 801), and Warm Springs and Hot Springs, Va. (no's. 631, 607, and 602), have cation thermometer temperatures in reasonable agreement with both measured and chalcedony temperatures. The coolest of these are samples $607 \mathrm{~A}$ and $\mathrm{B}$, which are about $20^{\circ} \mathrm{C}$. Other samples, however, such as 301 and 702, with measured temperatures above $20^{\circ} \mathrm{C}$ have negative cation temperatures. Because all samples above $30^{\circ} \mathrm{C}$ do have reasonable cation temperatures, this might be a minimum temperature for reliability of this geothermometer.

At relatively low temperatures $\left(<50^{\circ} \mathrm{C}\right)$, geothermometer estimates will not be particularly accurate because the basic premise behind their operation may not be valid, that is, equilibrium of the temperature dependent reaction may not be attained. However, fair success of the chalcedony and cation thermometers is indicated by the data for the warmest of the Appalachian spring systems. This agreement between chalcedony, rather than quartz, with measured and cation temperatures, together with the relatively low $\left(<50^{\circ} \mathrm{C}\right)$ maximum temperatures suggests that chalcedony rather than quartz is controlling the silica concentrations in these systems.

\section{DISCUSSION}

\section{SILICA-ROCK SPRING SYSTEMS}

The Perry County, Pa., Warm Springs (201) and Berkeley Springs (301) and Minnehaha Springs (401), W. Va., issue from the Oriskany Sandstone; and the Georgia Warm Springs (901), from the Hollis Quartzite. Certain chemical characteristics of these springs are similar because of their similar aquifer rock type, and it is convenient to discuss them together. All have relatively low concentrations of dissolved solids-181 to $258 \mathrm{mg} / \mathrm{L}$-as compared to the values of 266 to $848 \mathrm{mg} / \mathrm{L}$ in waters from carbonate rocks. A trace of dissolved helium was found in only one sample from Minnehaha Springs (401), and none was found in any of the other three silica-rock warm springs. Generally higher helium levels were found in samples from the carbonate warm springs and hot wells.

The four silica-rock thermal springs contain little (201) to no (901) tritium, and all but Minnehaha Springs (401) are significantly undersaturated with calcite and have $\delta^{13} \mathrm{C}$ values of $-13 \%$ or more negative. These undersaturated waters could not have been exposed for any extended period to aquifer rock containing carbonate minerals, and so they must have flowed from recharge to discharge through the lowcarbonate sandstones from which they issue. Although Minnehaha Springs (401) issues from the Oriskany 
Sandstone, the water is saturated with calcite. This spring is in the vicinity of the Virginia thermal springs, all of which are associated with limestone. The fact that Minnehaha Springs is saturated with calcite suggests that, unlike the other sandstone springs, its water has been exposed to carbonate rock.

\section{PERRY COUNTY, PA., AREA}

Waters from warm spring 201 and samples 202 and 216 are derived from the Devonian Oriskany Sandstone. Spring 218 issues from the Silurian Tonoloway Limestone. The sample from spring 218 , with a tritium content of $78 \mathrm{TU}$ (fig. 22 and table 4), is virtually entirely modern water, and the concentrations of chloride, nitrate, and sulfate suggest the possibility of human influence on the water composition. The Oriskany Sandstone samples are all dilute calcium bicarbonate waters. The only pronounced compositional differences between the warm spring and the other two waters are the slightly elevated silica content and the generally higher mineralization of the warm spring, suggesting a longer period of flow in the aquifer for this sample. The quartz geothermometer temperature for the 1975 sample from spring 201 is probably a conservative estimate of maximum temperatures at depth in the aquifer.

BERKELEY SPRINGS, W. VA., AREA

The warm springs issue from the Oriskany Sandstone. Well 302 taps both the Oriskany and the overlying Marcellus Shale, whereas well 303 is entirely in the shale. Sample 307 is from a well completed in the Tonoloway Formation. The waters are of calcium bicarbonate and calcium-magnesium bicarbonate types, with relatively high sulfate in waters from the shale. The thermal-spring water is the most dilute water of those sampled in the area; sample 307, which from its tritium content of $72 \mathrm{TU}$ appears to be all modern water, is the most highly mineralized sample.

Silica temperatures are highest for wells 302 and 303 in the Marcellus Shale. These waters are supersaturated with chalcedony at the observed temperatures (fig. 22). However, recharge to the shale in this area is local and the measured tritium levels suggest that these samples contain about 50 percent recent recharge. Measured temperatures do not indicate significant local heating of the rock; therefore, the high silica contents in these samples very likely result from silica from weathering reactions having had insufficient time to equilibrate with the more stable chalcedony phase.

Indicated cation thermometer temperatures are all much lower than observed temperatures; however, predicted temperatures for the warm springs are the highest in this group of samples. The relatively high potassium content of the spring water appears to be the only significant chemical indicator that may be associated with the source of heat. There is little likelihood that temperatures at depth in this aquifer system would exceed the indicated temperature of about $38^{\circ} \mathrm{C}$ for the warm spring.

MINNEHAHA SPRINGS, W. VA., AREA

The warm springs in this area flow from the Oriskany Sandstone. The calcium bicarbonate compositions of the waters are generally similar to those in the Perry County and Berkeley Springs areas, except that sulfate constitutes almost 30 percent of the anion equivalents in the Minnehaha warm spring samples 401. Well 402 is completed in the Hamilton Formation, stratigraphically above the Oriskany. Samples 403 and 407 from the Oriskany Sandstone contain high $(>20$ $\mathrm{mg} / \mathrm{L}$ ) nitrate concentrations, and well 407 , with a tritium concentration of $88 \mathrm{TU}$, is modern water. Compositions of these well waters are very likely affected by human activities. Spring 406 issues from the Tonoloway Formation. Its tritium level of $63 \mathrm{TU}$ indicates that this calcium bicarbonate water is also recent.

Highest silica concentrations in the Minnehaha Springs area samples are found in well 402. The water is near equilibrium with chalcedony at the observed water temperature, whereas warm spring water 401 is considerably below chalcedony saturation. As is the case in the Berkeley Springs area, the stratigraphically and hydraulically higher formation contains young (high tritium) water, which according to the silica geothermometers, has been heated more than the thermal spring water in the area. Cation temperatures for spring 401 and well 402 , although much lower than observed temperatures, do correspond with the observed trend in temperature. Levels of potassium in the warm-spring and well waters are similar to those noted at Berkeley Springs. Also the observed trace of dissolved helium in the 1975 warm spring sample suggests that the spring water has undergone some heating.

High temperatures at depth in the aquifer do not appear likely; the quartz thermometer temperature indicated for the warm spring water (about $34^{\circ} \mathrm{C}$ ) is probably a conservative estimate of maximum temperature for water in the Oriskany Sandstone in this area.

$$
\text { WARM SPRINGS, GA., AREA }
$$

The warm spring (901) and cold spring (905) flow from the lower Paleozoic Hollis Quartzite. Hot well 907 penetrates the younger Manchester Schist, but it may 
also draw water from the underlying Hollis Quartzite. Well 909 is completed in the Carolina(?) Gneiss of former usage, which is older than the Hollis Quartzite.

Spring 905 yields extremely dilute, modern water with a composition unlike that of the warm spring. Chemically, the warm-spring and hot-well waters are similar. Both are waters of calcium-magnesium bicarbonate type, and relatively high in dissolved oxygen. The concentration of dissolved solids in the spring water is slightly higher than that in the hot well water (table 4). Well 909 differs from the warm spring and hot well in that sodium amounts to 25 percent of its cation equivalents, and dissolved oxygen is very low.

Tritium analyses indicate that spring 905 is almost entirely modern water, and that water from well 909 is approximately half young water. Warm spring 901 and hot well 907 do not contain significant components of modern water.

Chalcedony- and cation-thermometer temperatures are in fair agreement with each other and with the observed temperatures for the warm spring and hot well. The hot well probably draws water from the same source that supplies the spring. The agreement between geothermometer and observed temperatures for these waters indicates that the reservoir temperature in the warm spring system is approximately equal to the surface temperature of the water; little heat has been lost by conduction, and no evidence of mixing is apparent from the data.

Sample 909 geothermometer temperatures are also in good agreement with each other, but they are considerably higher than the observed temperature. The agreement between the chalcedony and cation geothermometers may be fortuitous; high dissolved silica may result from low-temperature surface weathering reactions, and mixing of two cold waters can result in mixed-water compositions from which high cation temperatures would be predicted. If well 909 is indeed a mixture of hot and cold water which has been cooled conductively, the hot reservoir temperature can be calculated as follows. From the tritium content of this sample (15 TU) and that estimated for shallow ground water in the area (35 TU, fig. $21 B$ ), the sample appears to contain about 45 percent cool, shallow water. If the silica content of this water is $7.0 \mathrm{mg} / \mathrm{L}$ (from samples 905 representing high-tritium, local, shallow ground water), the silica content of the hot water can be calculated to be about $50 \mathrm{mg} / \mathrm{L}$, which corresponds to a chalcedony temperature of $70^{\circ} \mathrm{C}$ for the hot component. A similar calculation for the cation temperature of the hot component of sample 909 gives $53^{\circ} \mathrm{C}$, which is below the chalcedony temperature. This suggests that deep waters hotter than $60-70^{\circ} \mathrm{C}$ probably do not exist in this area.
CARBONATE-ROCK SPRING SYSTEMS LEBANON SPRINGS, N.Y., AREA

The spring and wells sampled in the Lebanon Springs area all tap the Stockbridge Limestone of Early Cambrian to Early Ordovician age. Well 114 also draws water from the overlying Walloomsac Slate. Samples 101, 109, and 116 are calcium-magnesium bicarbonate waters; sample 114 is of the calcium sulfate type. The close similarity in chemical composition of waters from the thermal spring (101) and artesian well 109 suggest that they may be derived from the same source. Seasonal chemical variability in spring 101 probably results from changes in proportions of modern water feeding the spring, as indicated by the tritium analyses (table 4). This temporal variability has diminished, tritium has decayed, and heat has been lost by conduction by the time the water reaches well 109.

Wells 114 and 116 were sampled to provide data for comparison with the spring analyses. These waters were thought to be typical of shallow wells in the Stockbridge Limestone. However, sample 114 is a calcium sulfate water, unlike that of the spring. Sample 116 is chemically similar to the warm spring water, although relatively higher in total dissolved minerals and depleted in dissolved oxygen and in tritium; the chemical composition indicates that this water has been in the aquifer longer than the spring water. On the other hand, spring 101 and well 109 samples are higher in potassium, chloride, bromide, and strontium than is the well 116 water, and the samples contain detectable amounts of helium. These differences may be associated with the path of circulation and the source of heat for the spring. The amount of dissolved helium in the warm spring, $=1 \mu \mathrm{g} / \mathrm{L}$, indicates that the water may have been heated by as much as $35^{\circ} \mathrm{C}$.

Neither the silica nor the cation geothermometer indicates a high reservoir temperature for any of the samples from the Lebanon Springs area. If the spring water is assumed to consist of a mixture of a heated, quartz-saturated old component with 13 percent of a cold, modern water with negligible silica, then the silica content of the undiluted thermal water would be $1 \div(1-0.13) \times 12=14 \mathrm{mg} / \mathrm{L} \mathrm{SiO}_{2}$, and the corresponding quartz temperature would be $51^{\circ} \mathrm{C}$. (The estimate of 13 percent is based on the measured tritium content of 11.6 TU, as compared with the content of 90 TU estimated for fresh recharge; see fig. 21B.) This value of temperature is probably a reasonable upper limit on aquifer temperatures at depth in the area.

The carbonate chemical parameters are in keeping with the source rock of these samples. Stockbridge Limestone samples 109 and 116, with no tritium and hence an age greater than 20 years, are saturated with 
calcite and have $\delta^{13} \mathrm{C}$ values suggesting that their dissolved carbonate is about an equal mixture of soil-air $\mathrm{CO}_{2}\left(\delta^{13} \mathrm{C}=\mathrm{O} 25 \%\right.$ on $)$ and marine limestone $\left(\delta^{13} \mathrm{C}=0 \%{ }_{00}\right)$. Lebanon Springs itself (101) and sample 114 may be slightly undersaturated with calcite. Lebanon Springs contains tritium, and it is thus an admixture of water too young, perhaps, to have reached calcite saturation. Sample 114 draws water, in part, from the Walloomsac Slate, which may contain too little calcite to permit calcite saturation to be attained.

BOLAR SPRINGS, WARM SPRINGS, HOT SPRINGS, AND FALLING SPRING, VA., AREAS

The warm springs sampled in these areas flow from the Ordovician Lowville Limestone; sample 633 is from the Silurian rocks of Clinton age; the other cold springs and cold wells sampled draw water from the Lowville Limestone, or from the Trenton Limestone, and Martinsburg Shale or rocks of Black River age, which include the Lowville Limestone. Hot wells 607 and 702, completed in the Lower Ordovician Beekmantown Group, draw water from elevations below those of nearby springs in the Lowville Limestone. Sample $607 \mathrm{~A}$ represents a mixed water consisting of components from two or more producing zones. The February 1976 samples from well 607 , on the other hand, were obtained from isolated intervals; sample 607B represents the upper aquifer water and sample 607D is from the deepest water-bearing zone.

Except for the extremely dilute sample 633, dissolved solids of the waters sampled in the four areas ranged from 288 to $1,260 \mathrm{mg} / \mathrm{L}$ (table 4 ). Calcium and magnesium account for nearly all the dissolved cations; bicarbonate and sulfate in varying proportions are the major anions.

Small amounts of dissolved helium were found in one or more of the samples taken from the warm springs and hot wells in the four areas and in one sample from spring 619. The concentration of helium in hot well 702 , about $2 \mu \mathrm{g} / \mathrm{L}$, suggests that this water may have been heated by as much as $70^{\circ} \mathrm{C}$. Tritium in warm springs 501 and 701 indicates that these samples contain one-third to one-half modern water; presumably the temperature of the older component may be substantially higher than the observed temperatures of the flowing springs.

The carbonate chemistry of these thermal springs is in keeping with their origin from a carbonate rock. All are saturated with calcite, and their $\delta^{13} \mathrm{C}$ values are more positive than $-10 \%$. Calcite saturation and $\delta^{13} \mathrm{C}$ values in this range are typical of waters of moderate to long residence times in limestone.

Boiler Spring (602), which is saturated with dolomite as well as with calcite, has a $\delta^{13} \mathrm{C}$ value more positive than $-6 \%$. $\delta^{13} \mathrm{C}$ values in this range, with calcite and dolomite saturation, suggest either that the Boiler Spring water had a longer residence time than that of the other springs or that the other springs are mixtures of a Boiler Springlike water with a younger water.

Comparisons of observed temperatures with silica thermometer temperatures for the warmest springs (602 and 631) and for hot well sample 607D indicate slight undersaturation of the waters with chalcedony. Cation thermometer temperatures for these samples are in fair agreement with observed temperatures, and here, as in other warm spring areas, the higher cation temperatures are associated with relatively elevated potassium levels in the waters. Relatively high cation temperatures are indicated for spring 701; nearby hot well 702 , with an observed temperature higher than that of the spring, has a predicted cation temperature of $<0^{\circ} \mathrm{C}$. On the other hand, indicated silica temperatures for these samples are in the reverse order. The modern water component of the hot-well sample, indicated by its tritium content, apparently influences the mixed-water chemistry enough to invalidate the cation thermometer results.

Samples 701 and 702 can be interpreted as mixed, conductively cooled waters, and by making certain assumptions, the maximum probable temperature of their hot component can be calculated. Thus, if it is assumed that the tritium content of the thermal component is $0 \mathrm{TU}$ and that of the local cold ground water in the autumn of 1975 was $64 \mathrm{TU}$ (fig. 21B), the tritium contents of samples 701 and 702 suggest that the samples contain about 60 and 85 percent of a thermal component, respectively. If it is further assumed that the silica content of the cold ground water is $7 \mathrm{mg} / \mathrm{L}$, the silica content of the hot component can be calculated using the expression

$$
\mathrm{SiO}_{2_{\text {hot }}}=\frac{\mathrm{SiO}_{2_{\text {mix }}}-7 \times \text { proportion cold }}{\text { proportion hot }}
$$

The silica content of the hot component of both samples calculated this way is about $26 \mathrm{mg} / \mathrm{L}$; this figure corresponds to a chalcedony equilibrium temperature of $40^{\circ} \mathrm{C}$. It is not possible to calculate a cation temperature of the undiluted thermal component because values for the calcium, sodium, and potassium contents of the cold component are not known. However, the cation geothermometer expression (above) includes the cation concentrations as ratios and so mixing with a presumably dilute water should not significantly change the calculated temperature. Thus, for samples 701 , at least, the cation temperature supports the conclusion from the calculated chalcedony temperature that the 
maximum temperature of the thermal component is about $40^{\circ} \mathrm{C}$.

The occurrence of large warm springs issuing from the Lowville Limestone over a distance of more than 15 miles, and the good yields of warm water from the two wells in the Beekmantown nearly 10 miles apart suggest the existence of an extensive warm reservoir in this part of the Appalachians. Boiler Spring (602) and the warm component of the mixtures 701 and 702 have concordant chalcedony, cation, and measured temperatures that suggest this reservoir is at about $40^{\circ} \mathrm{C}$.

$$
\text { HOT SPRINGS, N.C., AREA }
$$

Waters sampled in the area are from rocks of Cambrian age. Warm spring 801 and well 810 are in the Shady Dolomite. Spring 805 flows from the overlying Rome Formation, whereas wells 803 and 804 are completed in the older Murray Shale and Hesse Quartzite, respectively. Although the warm spring is saturated with dolomite, its gross chemistry is predominantly of the calcium sulfate type, unlike the water from Shady Dolomite well 810 , which contains equivalent amounts of calcium and magnesium as major cations and bicarbonate as the predominant anion. Spring 805 is similar in chemical type to the water from well 810 . The warm spring water, in addition to being of a different chemical type, is also more highly mineralized than are the other samples from the area (table 4).

Well 803 water is unusual in that iron accounts for nearly 18 equivalent percent of the cations. Highly reducing conditions in the aquifer are indicated by the presence of measurable concentrations of dissolved methane in the water. On the other hand, measurable oxygen was present at the time of sampling, as shown by determinations in the field of dissolved oxygen, and the high tritium concentration indicates a modernwater component of about 80 percent. Apparently, when this well is pumped, a large amount of shallow, modern, oxygenated water is drawn up with the highly reducing older water in the shale, resulting in an unstable solution containing ferrous iron and dissolved oxygen. The oxygen is rapidly consumed, producing a voluminous precipitate of ferric hydroxide within a few minutes after sampling.

Tritium levels indicate that samples 804 and 810 are nearly entirely recent water. Spring 805 contains a lesser component of young water, while the warm spring (801) contains only relatively old water. Small quantities of dissolved helium were found in the warmspring water but not in any other samples from the area. The higher helium concentration (from the sample collected in December 1975) may indicate heating of the water by radioactive decay processes to $24^{\circ} \mathrm{C}$ above normal ground-water temperatures.
The young waters from wells 804 and 810 are undersaturated with chalcedony; older water from cold spring 805 is near saturation. Warm spring 801 and well 803 water, on the other hand, are supersaturated with respect to chalcedony. The relatively low flow $(\sim 0.5 \mathrm{~L} / \mathrm{s})$ of the warm spring, as well as the observed seasonal variability in its temperature (table 4 and fig. 17 ), are consistent with the possibility of appreciable conductive cooling taking place between the heat source and the site at which the spring flows. If such conductive cooling occurs, then the water temperature near the heat source may be considerably greater than the measured outlet temperature, quite possibly as high as $50^{\circ} \mathrm{C}$ (equilibration with chalcedony). Cation thermometer temperatures suggest that the chalcedony temperature is the probable reservoir temperature.

If mixing rather than conductive cooling accounts for the observed chalcedony supersaturation of warm spring 801 , then a hot reservoir temperature can be calculated from the equations described above, using appropriate values of temperature and dissolved silica for the cold component and assuming chalcedony saturation of the hot water component. Solution of the equations requires an analytical expression for the chalcedony-temperature curve. An equivalent graphical solution can be obtained, as illustrated in figure 22 . Point A represents the December, 1975, warm spring sample. The cold component, at equilibrium with chalcedony at a temperature of $14.2^{\circ} \mathrm{C}$, is indicated as point B. Tie-line BA which extends to the high-temperature intersection with the chalcedony saturation curve at point $\mathrm{C}$, gives the temperature and dissolved silica content of the hot water component. This procedure yields a reservoir temperature of $77^{\circ} \mathrm{C}$ and silica content of 57 $\mathrm{mg} / \mathrm{L}$ for the hot water.

Interpretation of the thermal history of the water from well 803 is difficult. Quite possibly the high dissolved silica level derives from a lack of time for the silica from weathering reactions in the high-tritium cool water to reach equilibrium with chalcedony as seems to have occurred at the Berkeley Springs wells in the Marcellus Shale. The cation geothermometer could not be expected to predict accurate temperatures for the formation water because cation concentrations and ratios will be strongly influenced by the modern component of the mixed-water sample. The tritium content of water from well 803 can be interpreted as indicating that the 1975 sample contains about 20 percent hot and 80 percent cold water, and that the cold component contains $8 \mathrm{mg} / \mathrm{L} \mathrm{SiO}_{2}$. If this were the case, the undiluted hot component would have a silica content of about $90 \mathrm{mg} / \mathrm{L}$, corresponding to a chalcedony temperature of $105^{\circ} \mathrm{C}$. These temperatures exceed the 
concordant chalcedony and cation temperatures of sample 801 too much to be entirely credible, and it is thus likely that the high silica content of sample 803 is due to supersaturation with chalcedony at low temperature rather than to equilibrium at high temperature. Thus, in the Hot Springs, N.C., area, reservoir temperature predicted by the chalcedony geothermometer is $77^{\circ} \mathrm{C}$ if the warm spring is a mixture of hot and cold waters, or about $50^{\circ} \mathrm{C}$ if the spring is conductively cooled. Cation geothermometer results suggest that the lower temperature is the more likely.

\section{CONCLUSIONS}

All evidence accumulated thus far indicates that the heat at the thermal springs investigated is derived from rocks at depth in a region of "normal" geothermal heat flow. The spring waters are mixtures of warm, deep ground water and shallow, cool ground water in variable proportions. In general, the warmest springs discharge the highest proportion of deep-circulating warm water.

Many thermal springs are in valleys on the crests or flanks of anticlines where steeply dipping beds of sandstone or limestone intersect faults or lineaments. Some thermal springs are in areas of complex geology and are associated with faulted limestone or sandstone.

Deep circulation of most of the ground water discharging in the thermal springs is in the general direction of the strike of the rock strata, along open tension fractures, bedding planes, and faults. Some deep circulation possibly occurs also along fault planes crossing the strike of the rocks.

Further work would be required to confirm hydrologic interpretations at the sites studied. The best sites for further study might be Berkeley Springs, W. Va., and Hot Springs, Va., because of the availability of much hydrologic information for those areas. The interpretations made from studies of those sites probably would be applicable to many other thermal springs in the East.

Further work would be required to determine the geothermal potential of a particular site. Probably the best sites to consider for this type of study would be Falling Spring or Bolar Spring, Va. or Hot Springs, N. C.; these Virginia springs have the highest energy output of the ones included in this investigation. Although the Hot Springs in North Carolina have a visibly small discharge, there are reliable reports of hot water discharging beneath the French Broad River near the Hot Springs, and in the alluvium near the mouth of Spring Creek. Thus, the area probably has a much higher energy output than indicated for the spring in table 3 .

This study produced no evidence of very high reservoir temperatures in the aquifers. Oxygen-isotope ratios of the waters fall within ranges expected for recharge at the latitudes of the springs; no positive shift in $\delta^{18} 0$ is observed. Thus, temperatures at depth in the spring systems are almost certainly less than $150^{\circ} \mathrm{C}$.

Geothermometers cannot be expected to provide very accurate results in systems with low reservoir temperatures. Observed high dissolved-silica levels of some cold-water samples (such as those from wells 302, 303, and 402 , for example) which presumably have never been heated will obviously invalidate the estimates of temperature from the silica geothermometer and will also raise doubts about the indicated temperatures of nearby warm-spring waters. Nevertheless, a trend of increasing dissolved silica with increasing temperatures is observed in the Appalachian warm springs. Spring and hot-well samples at temperatures $>25^{\circ} \mathrm{C}$ have indicated chalcedony temperatures within about $10^{\circ} \mathrm{C}$ of the observed values, so that equilibration of dissolved silica with this mineral is clearly an important reaction associated with heating of the water. Cation-geothermometer temperatures of the warmest spring waters and of two of the three sampled hot-well waters are also in fair agreement with observed temperatures. The concordance of observed chalcedony, and cation temperatures for these warmest waters indicates that the chemical processes underlying the success of the cation geothermometer in other systems are also operative in the Appalachian thermal springs, and further, that reservoir temperatures in these systems probably do not exceed the chalcedony values of $30^{\circ}-$ $50^{\circ} \mathrm{C}$.

Refinements can be made in geothermometer estimates of hot reservoir temperatures if the hot and cold components of a mixed warm water can be distinguished. Chemical analyses of cold-spring and well waters in the thermal spring areas proved inadequate for estimating the extent of mixing; the composition of the hot component could not be deduced from compositions of an assumed cold recharge water and the sampled spring water. However, tritium measurements distinguish clearly between modern and relatively old waters. Tritium determinations of fractions of cold (young) and hot (old) water, together with estimates of the silica content of the cold component, do provide improved silica geothermometer estimates of reservoir temperatures in some of the mixed spring systems.

Potassium and helium seem to be most significant among the qualitative geothermal indicators considered. Relatively high potassium levels (which are partly responsible for high cation geothermometer temperatures) are found in the warmer springs and in two of the three hot wells. Dissolved helium is present, in amounts from traces to several tenths of a $\mu \mathrm{g} / \mathrm{L}$, in 
most of the warm springs issuing from carbonate rocks. Only one sample from the silica-rock warm springs contained a detectable amount of helium. Arsenic may also be a useful geothermal indicator for application in the Appalachian warm spring systems if analytical sensitivity for arsenic can be increased so that a few hundredths of a $\mu \mathrm{g} / \mathrm{L}$ can be determined with confidence.

Several observations regarding the geochemistry of the spring waters are apparent from the tabulated data. The tritium analyses show that the warm spring waters are older than those of nearby cold springs. Also, in several of the warm springs the values for $\delta^{13} \mathrm{C}$ are substantially higher than those in nearby cold springs; the high values indicate a longer or slower travel path in the formation of the warm water. Carbonate saturation indices for the thermal waters are higher than those calculated for nearby cold springs in the same formation. Three of the silica-rock warm springs are considerably undersaturated in calcite; the carbonate thermal waters and Minnehaha Springs, on the other hand, are near or above calcite saturation.

The technique of using analyzed carbon dioxide concentrations rather than field $\mathrm{pH}$ in calculations of carbonate equilibrium data helps considerably to reduce discrepancies between different samples from a spring of supposed constant composition and also to reduce or eliminate apparent carbonate supersaturation of a number of spring waters. The proposed method for determination of an adjusted $\delta^{13} \mathrm{C}$, using the gas analysis value for $\mathrm{CO}_{2}$, also leads to more nearly constant compositions for a number of the Appalachian springs. The resulting improvements in the geochemical data lend support to the idea that outgassing of carbon dioxide during the preparation of a ${ }^{13} \mathrm{C}$ sample, or in the course of measuring $\mathrm{pH}$, may lead to erroneous conclusions about the carbonate chemistry of a water sample. The use of analyzed carbon dioxide concentrations may be generally helpful in geochemical studies of ground waters.

\section{REFERENCES CITED}

American Assoc. Petroleum Geologists and U.S. Geological Survey, 1976, Geothermal gradient map of North America: U.S. Geol. Survey, 2 maps, 1:5,000,000.

Birch, F., 1954, Heat from radioactivity, Ch. 5 in H. Faul, Ed., Nuclear Geology: 414 p. and xvii, John Wiley \& Sons, New York.

Clark, W. E., Chisholm, J. L., and Frye, P. M., 1976, Water resources of the upper New River basin, West Virginia: West Virginia Geol. and Econ. Survey and West Virginia Dept. Nat. Resources, Div. Water Resources, River Basin Bull. 4.

Claypole, E. W., 1885, Second Geological Survey of Pennsylvania, Report F2, a preliminary report on the paleontology of Perry County: Board of Commissioners for the Second Geological Survey, Harrisburg, Pennsylvania, 437 p.

Costain, J. K., 1976, Geology and geophysical study of the origin of the Warm Springs in Bath County, Virginia: Virginia Polytechnic Inst. and State Univ., Dept. of Geol. Sci., 44 p.

Dansgaard, W., 1964, Stable isotopes in precipitation: Tellus, v. 16, p. $436-468$.

Dennison, J. M. and Johnson, R. W., Jr., 1971, Tertiary intrusions and associated phenomena near the Thirty Eighth parallel fracture zone in Virginia and West Virginia: Geol. Soc. Am. Bull., v. 82 , pp. $501-508$.

Fournier, R. O., 1973, Silica in thermal waters: laboratory and field investigations: Proc. of the International Symp. on Hydrogeochemistry and Biogeochemistry, Tokyo, 1970, v. 1-Hydrogeochemistry, Clark, Washington, D. C., p. 122-129.

Fournier, R. O., and Truesdell, A. H., 1973, An empirical Na-K-Ca geothermometer for natural waters: Geochim. et Cosmochim. Acta, v. 37, p. $1255-1275$.

1974, Geochemical indicators of subsurface temperaturePart 2, Estimation of temperature and fraction of hot water mixed with cold water: U.S. Geol. Survey Jour. Research, v. 2, no. 3 , p. 263-270.

Fournier, R. O., White, D. E., and Truesdell, A. H., 1974, Geochemical indicators of subsurface temperature-Part 1, Basic assumptions: U.S. Geol. Survey Jour. Research, v. 2, no. 3, p. 259-262.

Grimsley, G. P., 1916, Jefferson, Berkeley, and Morgan Counties: West Virginia Geol. and Econ. Survey County Geologic Rept. Series, 644 p., $3 \mathrm{pl}$.

Heltz, G. R. and Sinex, S. A., 1974, Chemical equilibria in thermal spring waters of Virginia: Geochim. et Cosmochim. Acta, v. 38, pp. 1807-1820.

Hewett, D. F. and Crickmay, G. W., 1937, The Warm Springs of Georgia, their geologic relations and origin: U.S. Geol. Survey Water-Supply Paper 819, 40 p.

Hobba, W. A., Jr., Chemerys, J. C., Fisher, D. W., and Pearson, F. J., Jr., 1977, Geochemical and hydrologic data for wells and springs in thermal-spring areas of the Appalachians: U.S. Geol. Survey Water-Resources Investigations Report 77-25, $36 \mathrm{p}$.

Hobba, W. A., Jr., Friel, E. A., and Chisholm, J. L., 1972, The water resources of the Potomac River basin, West Virginia: West Virginia Geol. and Econ. Survey and the West Virginia Dept. Nat. Resources, Div. Water Resources, River Basin Bull. 3.

Keith, Arthur, 1904, Description of the Asheville quadrangle (North Carolina-Tennessee): U.S. Geol. Survey Geol. Atlas, Folio 116.

Kulander, B. R., and Dean, S., 1972, Gravity and structures across Browns Mountain, Wills Mountain, and Warm Springs anticlines-gravity study of the folded plateau, West Virginia, Virginia, and Maryland, in Lessing, Peter, ed., Appalachian structures: origin, evolution, and possible potential for new exploration frontiers-a seminar: West Virginia University and West Virginia Geol. and Econ. Survey, p. 141-180.

Langmuir, Donald, 1971, The geochemistry of some carbonate ground waters in central Pennsylvania: Geochim. et Cosmochim. Acta, v. 34, p. 1023-1045.

Li, Yuan-Hui, Takahashi, T. and Broecker, W. S., 1969, Degree of saturation of $\mathrm{CaCO}_{3}$ in the oceans: Jour. Geophys. Research, v. 74 , no. 23 , p. $5507-5525$.

Lohman, S. W., 1972, Ground-water hydraulics: U.S. Geol. Survey Prof. Paper 708, 70 p.

Lowell, Robert P., 1975, Circulation in fractures, hot springs, and convective heat transport on mid-ocean ridge crests: Geophys. Jour. Research Astr. Soc. 40, p. 351-365.

Mather, W. W., 1842-43, Geology of New York-Part 1, Geology of the first geological district: Albany, New York, Carroll and Cook.

McCallie, S. W., 1908, A preliminary report on the underground waters of Georgia: Geol. Survey of Georgia, Bull. 15, 370 p. 1913, A preliminary report on the mineral springs of Georgia: 
Geological Survey of Georgia Bull. 20, $190 \mathrm{p}$.

Oriel, S. S., 1950, Geology and mineral resources of the Hot Springs Window, Madison County, North Carolina: North Carolina Dept. Conserv. Devel., Div. Mineral Res., Bull. 60, 70 p.

Park, P. Kilho, 1969, Oceanic $\mathrm{CO}_{2}$ system: An evaluation of ten methods of investigation: Limnol. and Oceanog., v. 14, no. 2, p. 179-186.

Pearson, F. J., Jr., Fisher, D. W., and Plummer, L. N., in preparation, Correction of ground-water chemistry and isotopic composition for the effects of $\mathrm{CO}_{2}$ outgassing: Geochim. et Cosmochim. Acta.

Pearson, F. J., Jr., and Rettman, R. L., 1976, Geochemical and isotopic analyses of waters associated with the Edwards Limestone Aquifer, Central Texas: Edwards Underground Water District Report, San Antonio, Texas, $35 \mathrm{p}$.

Plummer, L. Niel, Jones, Blair F., and Truesdell, Alfred H., 1976, WATEQF-A Fortran IV version of WATEQ, a computer program for calculating chemical equilibrium of natural waters: U.S. Geol. Survey Water-Resources Investigations Report 76-13, $61 \mathrm{p}$.

Price, P. H., Hoskins, H. A., and McCue, J. B., 1936, Springs of West Virginia: West Virginia Geol. Survey, $146 \mathrm{p}$.

Reeves, Frank, 1932, Thermal springs of Virginia: Virginia Geol. Survey, Bull. $36,56 \mathrm{p}$.

Roberts, A. A., Friedman, I., Donovan, T. J., and Denton, E. H., 1975, Helium survey, a possible technique for locating geothermal reservoirs: Geophys. Research Letters, v. 2, no. 6, p. 209-210.

Rogers, W. B., 1843, On the connection of thermal springs in Virginia with anticlinal axes and faults: Assoc. Am. Geologists and Naturalist, Report of 1st, 2nd, and 3rd meetings 1840-1842, p. 323-347.

1884, A reprint of the annual reports and other papers on the geology of the Virginias, by the late William Borton Rogers: New York, D. Appleton and Co., 832 p., 8 pls, map, and 8 charts.
Siddiqui, S. H., and Parizek, R. R., 1972, Application of nonparametric statistical tests in hydrogeology: Ground Water, v. 10, no. 2, p. 26-31.

Stewart, G. L., and Farnsworth, R. K., 1968, United States tritium rainout and its hydrologic implications: Water Resources Research, v. 4, p. 273-289.

Stewart, G. L. and Wyerman, T. A., 1970, Tritium rainout in the United States during 1966, 1967, and 1968: Water Resources Research, v. 6, p. 77-87.

Stose, G. W. and Stose, A. J., 1947, Origin of the hot springs at Hot Springs, N. C.: Am. Jour. Sci., v. 245, p. 624-644.

Stumm, Werner, and Morgan, James J., 1970, Aquatic Chemistry: New York, Wiley-Interscience, $583 \mathrm{p}$.

Toth, J., 1963, A theoretical analysis of groundwater flow in small drainage basins: Jour. of Geophys. Research, v. 68 , no. 16, pp. 4795-4812.

Trapp, Henry, Jr., 1970, Geology and ground-water resources of the Asheville area, North Carolina: North Carolina Dept. of Water and Air Resources, Div. of Ground Water, Ground-Water Bull. 16.

Truesdell, A. H., 1976, Geochemical techniques in exploration: Proc. 2nd UN Symposium on the development and use of geothermal resources, p. liii-lxxix.

Weinman, B., 1976, Geophysical, geochemical, and remote sensing studies of Pennsylvania's thermal springs: Pennsylvania State University, unpublished MS Thesis.

Werner, E., and Medville, D., 1975, Relation of lineaments and hydrology in a carbonate terrain of West Virginia: EOS, v. 56, no. 6, p. 358 .

White, D. E., Barnes, Ivan, and O'Neil, J. R., 1973, Thermal and mineral waters of non-meteoric origin, California Coast Ranges: Geol. Soc. America Bull., v. 84, p. 547-560.

W. Va. Geol. and Econ. Survey, 1970, Oil and gas fields of West Virginia: 1:250,000 map. 